\title{
U.S. Geological Survey, National Wildlife Health Center, 2011 Report of Selected Wildlife Diseases
}
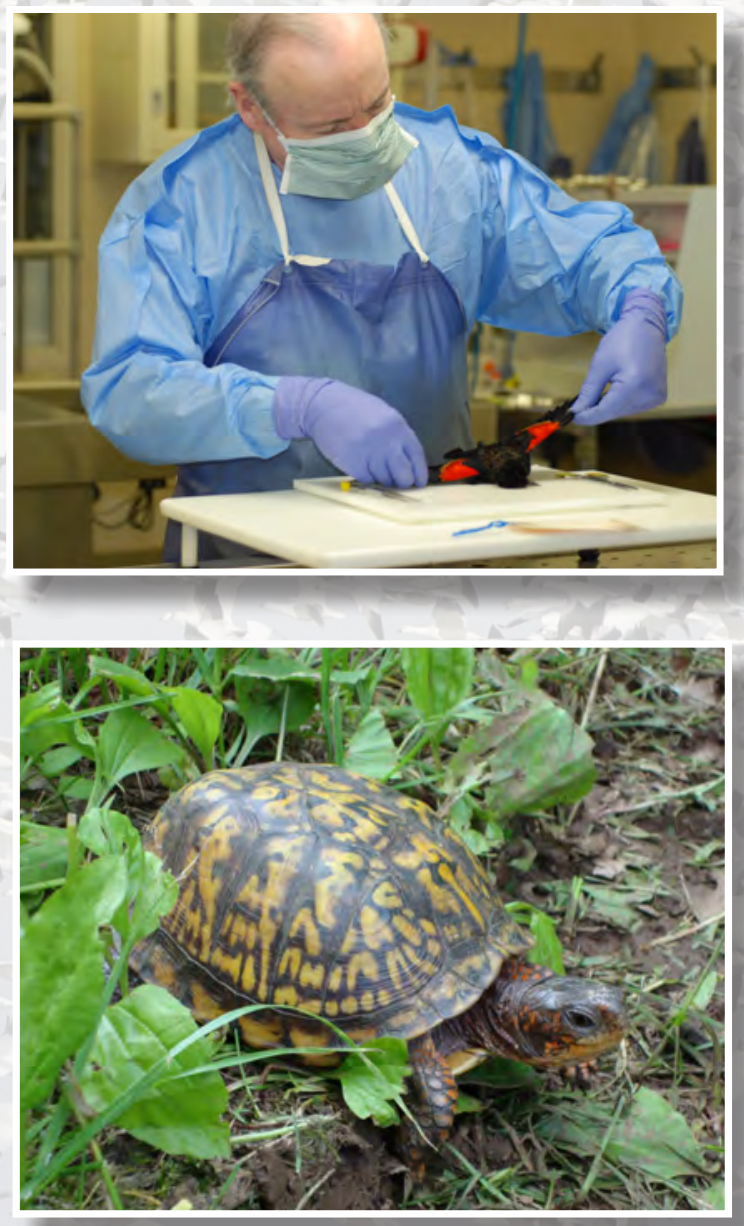
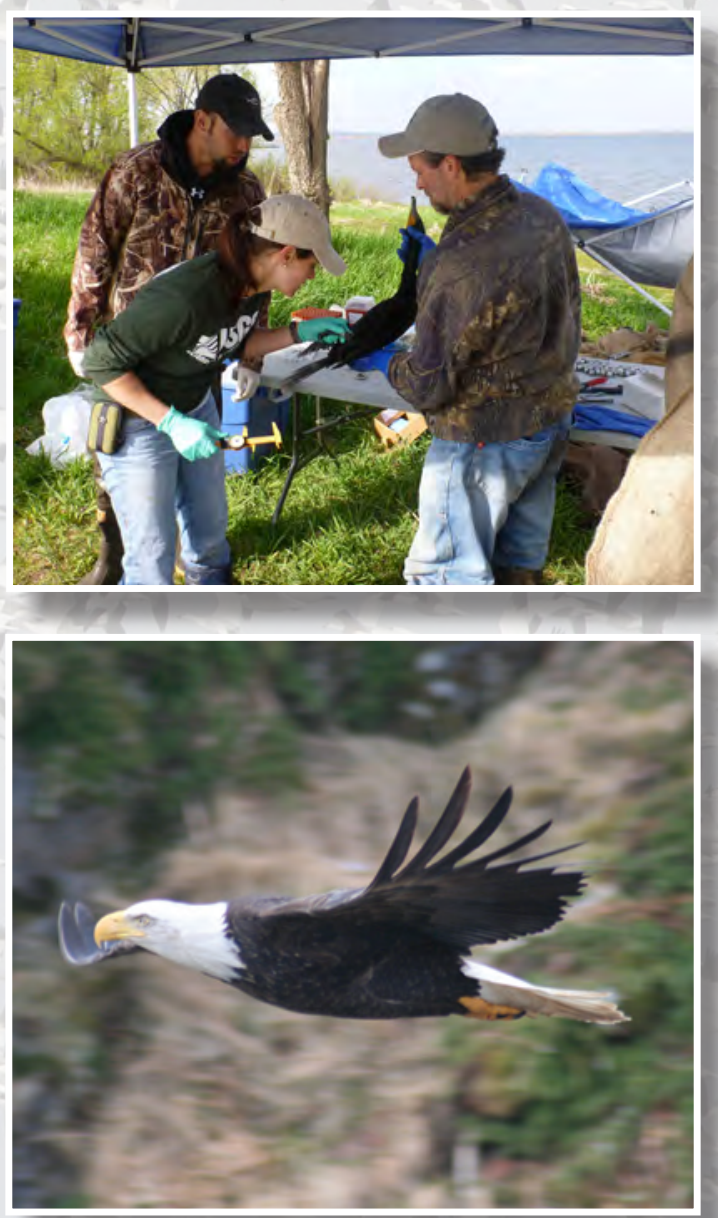

Scientific Investigations Report 2012-5271 
Cover images, clockwise, starting top left:

David Green, National Wildlife Health Center, with blackbird (Photo by Allison Klein) NWHC staff and partners with cormorant (Photo by C. LeAnn White)

Box turtle (Photo by Cindy Cunningham)

Bald eagle (Photo by J. Chris Franson)

Background photo of snow geese (Photo by Bob Dusek) 


\section{U.S. Geological Survey, National Wildlife Health Center, 2011 Report of Selected Wildlife Diseases}

By David Green, Megan Hines, Robin Russell, and Jonathan Sleeman

Scientific Investigations Report 2012-5271 


\title{
U.S. Department of the Interior \\ KEN SALAZAR, Secretary \\ U.S. Geological Survey \\ Marcia K. McNutt, Director
}

\author{
U.S. Geological Survey, Reston, Virginia: 2012
}

For more information on the USGS - the Federal source for science about the Earth, its natural and living resources, natural hazards, and the environment, visit http://www.usgs.gov or call 1-888-ASK-USGS.

For an overview of USGS information products, including maps, imagery, and publications, visit http://www.usgs.gov/pubprod

To order this and other USGS information products, visit http://store.usgs.gov

Any use of trade, firm, or product names is for descriptive purposes only and does not imply endorsement by the U.S. Government.

Although this information product, for the most part, is in the public domain, it also may contain copyrighted materials as noted in the text. Permission to reproduce copyrighted items must be secured from the copyright owner.

Suggested citation:

Green, D., Hines, M., Russell, R., and Sleeman, J., 2012, U.S. Geological Survey, National Wildlife Health Center , 2011 report of selected wildlife diseases: U.S. Geological Survey Scientific Investigations Report 2012-5271, 32 p. plus 1 app. 


\section{Acknowledgements}

We thank our many partners and submitters for their vigilance in monitoring for wild life disease outbreak events and for submitting cases to us for diagnostic evaluation.

\section{Contents}

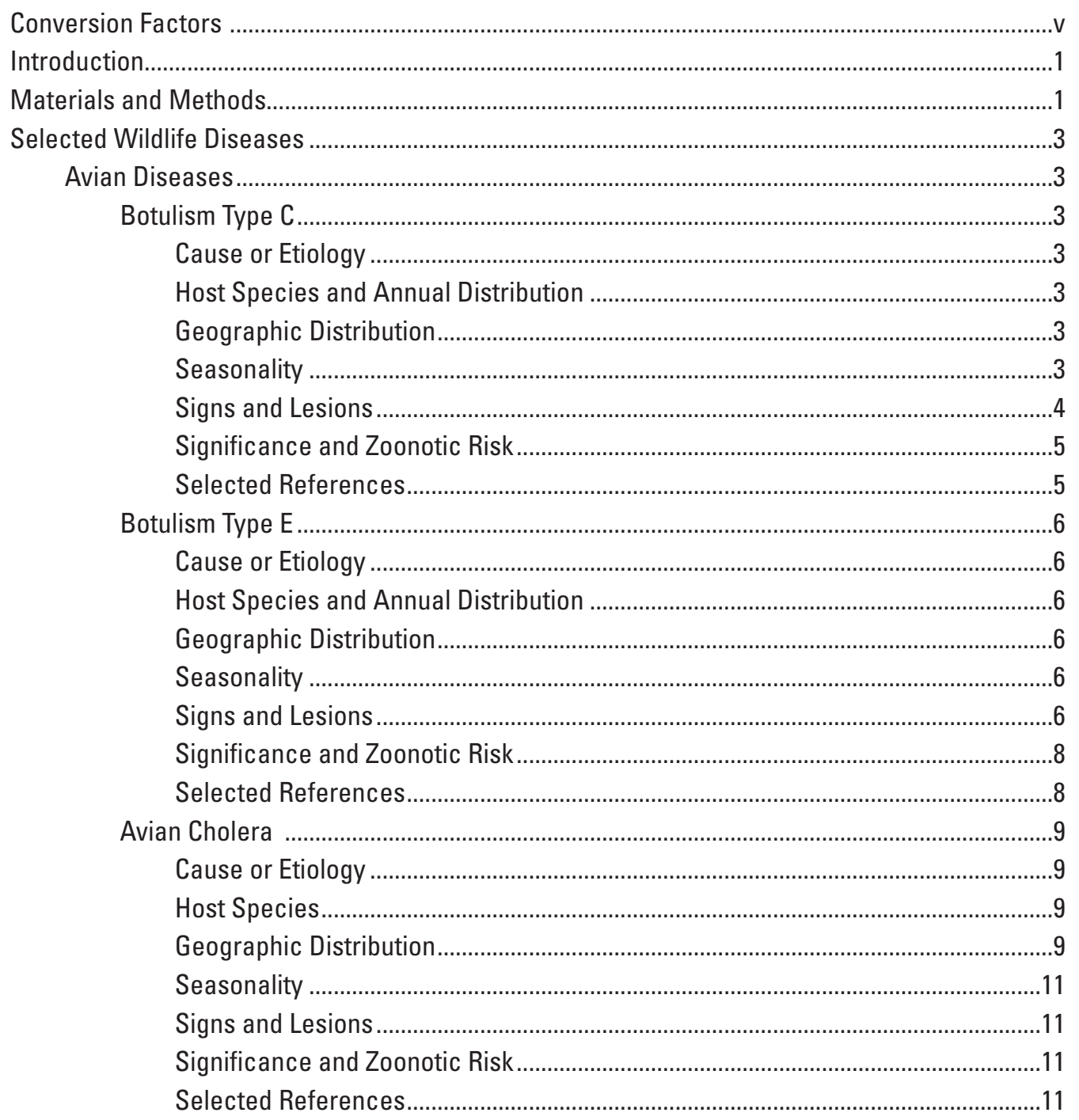




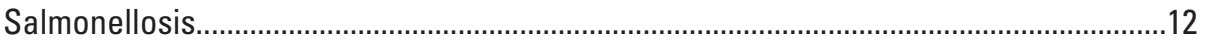

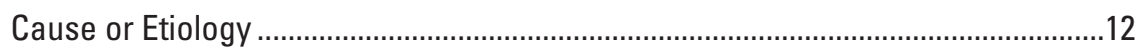

Host Species and Annual Distribution .................................................................12

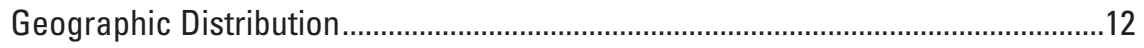

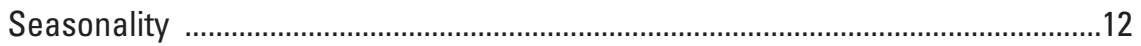

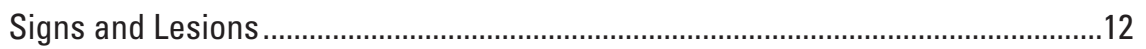

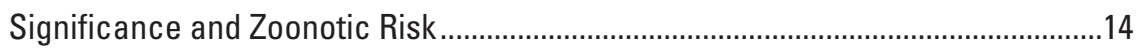

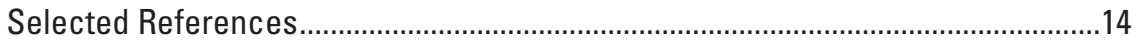

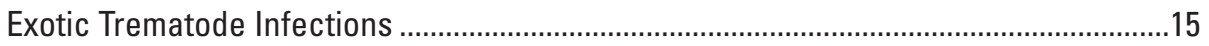

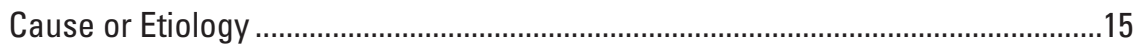

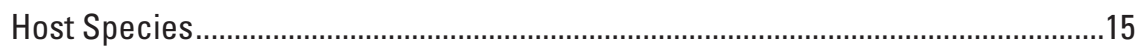

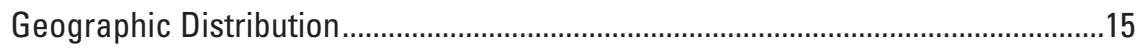

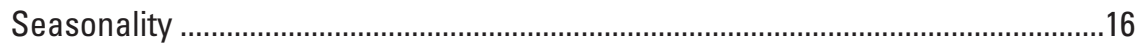

Signs and Lesions .............................................................................................17

Significance and Zoonotic Risk .........................................................................17

Selected References...........................................................................................

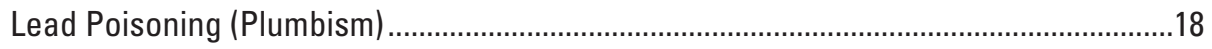

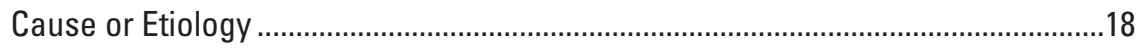

Host Species and Annual Distribution ................................................................18

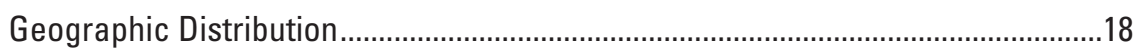

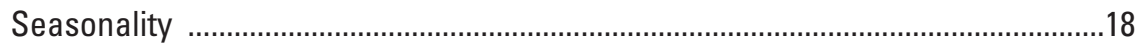

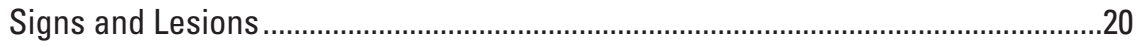

Significance and Zoonotic Risk .......................................................................20

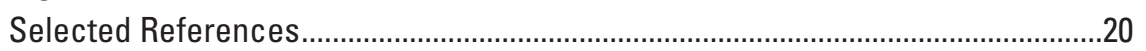

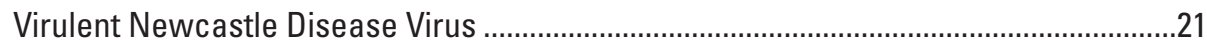

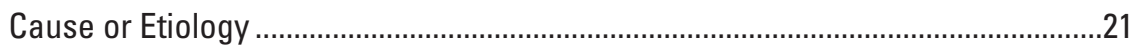

Host Species and Annual Distribution ................................................................21

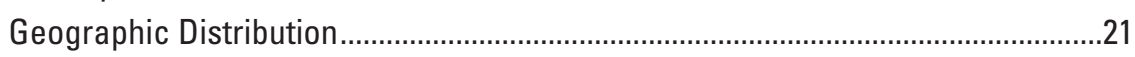

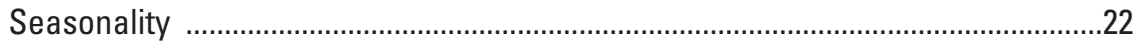

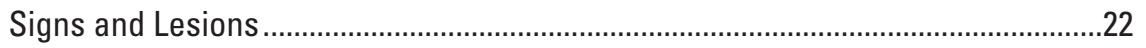

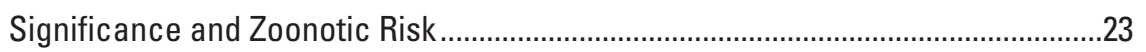

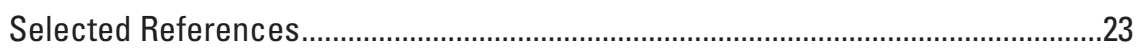

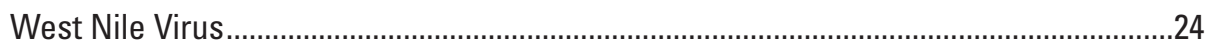

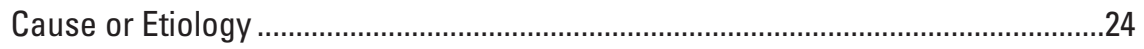

Host Species and Annual Distribution ..................................................................24

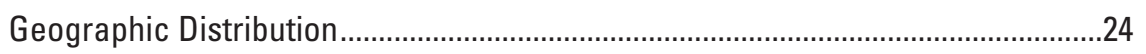

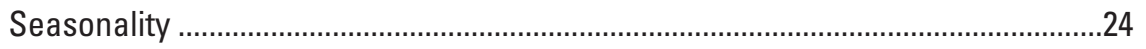

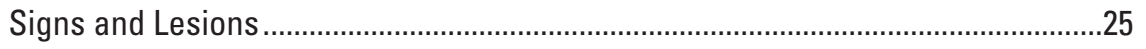

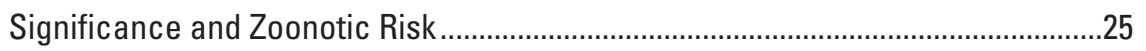

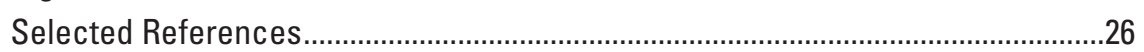




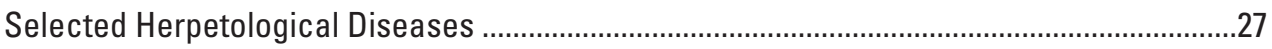

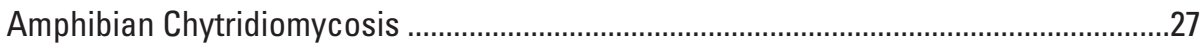

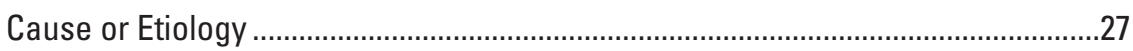

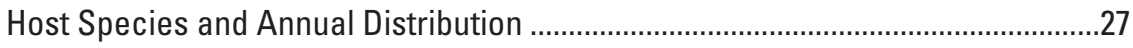

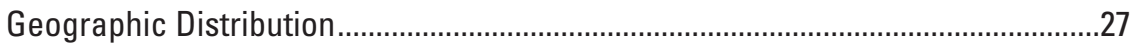

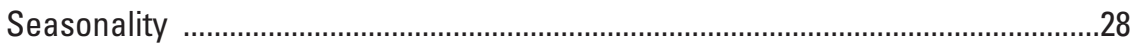

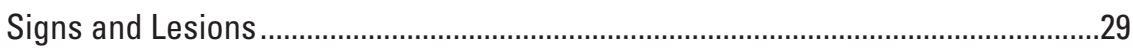

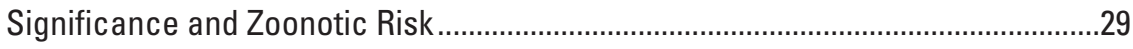

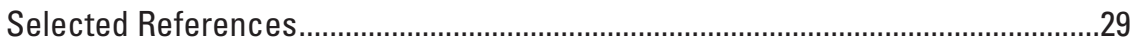

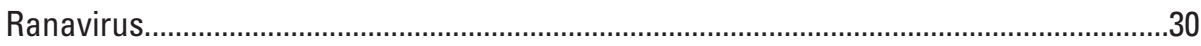

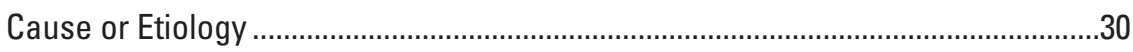

Host Species and Annual Distribution ..............................................................30

Geographic Distribution....................................................................................

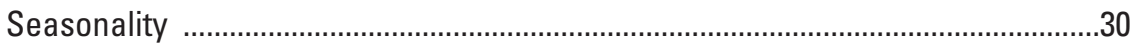

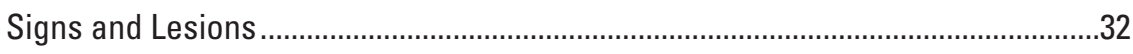

Significance and Zoonotic Risk ........................................................................32

Selected References...........................................................................................

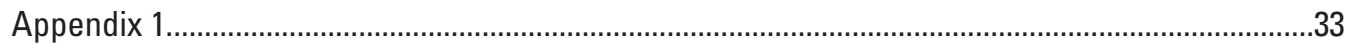

\section{Figures}

1. Graph showing occurrence of botulism type $C$ in wild birds $2001-10$, by order ................3

2. Maps showing prevalence of botulism $C$ diagnosed in wild bird disease outbreaks, as a percentage of all wild bird disease outbreaks, by State, for $A, 2001-5$ and $B, 2006-10$.

3. Graph showing monthly number of cases of botulism type $C$ in wild birds ......................5

4. Graph showing annual number of cases of botulism type $\mathrm{C}$ in wild birds ........................5

5. Graph showing occurrence of botulism type $E$ in wild birds 2001-10, by order ...............6

6. Maps showing prevalence of botulism $E$ diagnosed in wild bird disease outbreaks, as a percentage of all wild bird disease outbreaks, by State,

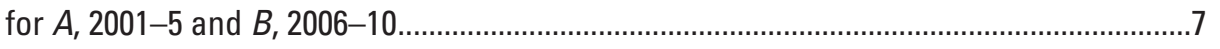

7. Graph showing annual number of cases of botulism type $E$ in wild birds ........................8

8. Graph showing monthly number of cases of botulism type $\mathrm{E}$ in wild birds ......................8

9. Graph showing occurrence of avian cholera in wild birds, 2001-10, by order .................9

10. Maps showing prevalence of avian cholera diagnosed in wild bird disease outbreaks, as a percentage of all wild bird disease outbreaks, by State,

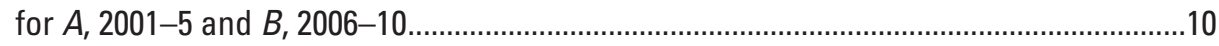

11. Graph showing annual number cases of avian cholera in wild birds ...........................11

12. Graph showing monthly number cases of avian cholera in wild birds ...........................11

13. Graph showing occurrence of salmonellosis in wild birds 2001-10, by order .................12

14. Maps showing prevalence of salmonellosis diagnosed in wild bird disease outbreaks, as a percentage of all wild bird disease outbreaks, by State,

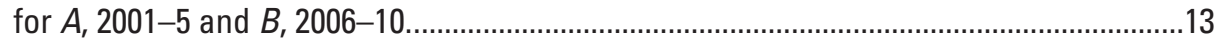

15. Graph showing annual number of cases of salmonellosis in wild birds........................14

16. Graph showing monthly number of cases of salmonellosis in wild birds.......................14

17. Graph showing occurrence of exotic trematode infections in wild birds 2001-10, by order 
18. Maps showing prevalence of exotic trematode infections diagnosed in wild bird disease outbreaks, as a percentage of all wild bird disease outbreaks, by State, for $A, 2001-5$ and $B, 2006-10$...

19. Graph showing annual number of cases of exotic trematode infection in wild birds ....17

20. Graph showing monthly number of cases of exotic trematode infection in wild birds ..17

21. Graph showing occurrence of lead poisoning in wild birds 2001-10, by order..... .18

22. Maps showing prevalence of exotic trematode infections diagnosed in wild bird disease outbreaks, as a percentage of all wild bird disease outbreaks, by State,

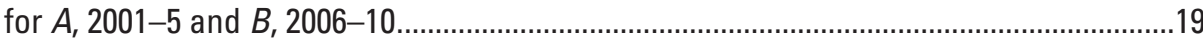

23. Graph showing annual number of cases of lead poisoning in wild birds .......................20

24. Graph showing monthly number of cases of lead poisoning in wild birds ......................20

25. Graph showing occurrence of virulent Newcastle disease virus in wild birds $2001-10$, by order

26 Maps showing prevalence of virulent Newcastle disease virus diagnosed in wild bird disease outbreaks, as a percentage of all wild bird disease outbreaks, by State, for $A, 2001-5$ and $B, 2006-10$...

27. Graph showing annual number of cases of virulent Newcastle disease virus in wild birds.

28. Graph showing monthly number of cases of virulent Newcastle disease virus in wild birds.

29. Graph showing occurrence of West Nile virus in wild birds 2001-10, by order .24

30. Maps showing prevalence of West Nile virus in wild bird disease outbreaks, as a percentage of all wild bird disease outbreaks, by State, for $A, 2001-5$ and $B, 2006-10$. .25

31. Graph showing annual number of cases of West Nile virus in wild birds .......................26

32. Graph showing monthly number of cases of West Nile virus in wild birds .....................26

33. Graph showing occurrence of chytridiomycosis in amphibians, by family ......................27

34. Maps showing prevalence of chytridiomycosis diagnosed in amphibians, as a percentage of all amphibian disease outbreaks, by State, for $A, 2001-5$ and $B, 2006-10$.

35. Graph showing annual number of cases of chytridiomycosis in amphibians..................29

36. Graph showing monthly number of cases of chytridiomycosis in amphibians................29

37. Graph showing occurrence of ranavirus in amphibians and turtles, by family ...............30

38. Maps showing prevalence of ranaviruses diagnosed in amphibian disease outbreaks, as a percentage of all amphibian disease outbreaks, by State,

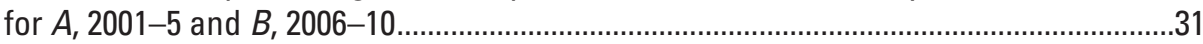

39. Graph showing annual number of cases of ranavirus in amphibians and turtles...........32

40. Graph showing monthly number of cases of ranavirus in amphibians and turtles.........32

\section{Conversion Factors}

SI to Inch/Pound

\begin{tabular}{|c|c|c|}
\hline Multiply & By & To obtain \\
\hline \multicolumn{3}{|c|}{ Length } \\
\hline meter (m) & 3.281 & foot (ft) \\
\hline
\end{tabular}

Temperature in degrees Celsius $\left({ }^{\circ} \mathrm{C}\right)$ may be converted to degrees Fahrenheit $\left({ }^{\circ} \mathrm{F}\right)$ as follows: ${ }^{\circ} \mathrm{F}=\left(1.8 x^{\circ} \mathrm{C}\right)+32$ 


\title{
U.S. Geological Survey, National Wildlife Health Center, 2011 Annual Report of Selected Wildlife Diseases
}

\author{
By David Green', Megan Hines², Robin Russell', and Jonathan Sleeman'
}

\section{Introduction}

The National Wildlife Health Center (NWHC) was founded in 1975 to provide technical assistance in identifying, controlling, and preventing wildlife losses from diseases, conduct research to understand the impact of diseases on wildlife populations, and devise methods to more effectively manage these disease threats. The impetus behind the creation of the NWHC was, in part, the catastrophic loss of tens of thousands of waterfowl as a result of an outbreak of duck plague at the Lake Andes National Wildlife Refuge in South Dakota during January 1973. In 1996, the NWHC, along with other Department of Interior research functions, was transferred from the U.S. Fish and Wildlife Service to the U.S. Geological Survey (USGS), where we remain one of many entities that provide the independent science that forms the bases of the sound management of the Nation's natural resources. Our mission is to provide national leadership to safeguard wildlife and ecosystem health through dynamic partnerships and exceptional science.

The main campus of the NWHC is located in Madison, Wis., where we maintain biological safety level 3 (BSL-3) diagnostic and research facilities purposefully designed for work with wildlife species. The NWHC provides research and technical assistance on wildlife health issues to State, Federal, and international agencies. In addition, since 1992 we have maintained a field station in Hawaii, the Honolulu Field Station, which focuses on marine and terrestrial natural resources throughout the Pacific region.

The NWHC conducts diagnostic investigations of unusual wildlife morbidity and mortality events nationwide to detect the presence of wildlife pathogens and determine the cause of death. This is also an important activity for detecting new, emerging and resurging diseases. The NWHC provides this crucial information on the presence of wildlife diseases to wildlife managers to support sound management decisions. The data and information generated also allows for further indepth analyses for determining the biological and ecological

\footnotetext{
${ }^{1}$ U.S. Geological Survey

${ }^{2}$ School of Veterinary Medicine, University of Wisconsin
}

significance of disease events, detecting disease trends over time and space, as well as detecting any significant changes to how diseases manifest in the field. Moreover, this information allows us to gain insight into the significance of future wildlife disease events.

The purpose of this report is to provide a sample of NWHC data that are available from our Laboratory Information Management System (LIMS). These data are presented in summary format with minimal statistical analysis and interpretation. The goal is to share these data with wildlife managers and other stakeholders, promote the use of NHWC data, and encourage the sharing of wildlife disease data to improve temporal and geographic surveillance coverage. Continued national surveillance for wildlife diseases is essential for providing early detection and warning of events that have the potential to result in harm to human health, economic losses, declines in wildlife populations, and subsequent ecological disturbances. Increased collaboration, coordination, and sharing of surveillance data will enhance this Nation's ability to detect and respond to wildlife disease threats.

\section{Materials and Methods}

Biological samples, mostly carcasses, are submitted voluntarily to the NWHC for diagnostic evaluation to determine the cause of death. These carcasses and samples constitute the basis of the data used in this report. After a group of carcasses or "submission" arrives at the NWHC, each submission is given a case number, and then each carcass within the submission is given an accession number. Multiple carcasses from a disease event are often submitted for diagnosis; therefore, each case number is usually associated with more than one accession number. These numbers-along with information regarding the species, geographic location where the carcass was found, the submitting agency, and the dates of collection and submission - are entered into the LIMS database at the NWHC. The diagnoses presented in this report were 
determined by NWHC pathologists using gross and histological evaluations and ancillary diagnostic tests as needed, and were based on published or established diagnostic criteria, including World Organization for Animal Health (OIE) published criteria where appropriate.

For the summaries contained within this report, we present data for diseases that are on the World Organization for Animal Health (OIE) list of reportable diseases or among the top 10 most common diagnoses at NWHC, or both. Background information about and data for eight avian diseases are included in the report: botulism C, botulism E, avian cholera, salmonellosis, exotic trematode infections, lead poisoning (plumbism), virulent Newcastle disease virus, and West Nile virus. Data for two diseases of amphibians and reptiles (herpetological diseases), chytridiomycosis and ranavirus infection, also are included. The number of cases of each disease is summarized in multiple ways: (1) the number of cases of each disease reported each year (the annual count); (2) the number of cases of each disease reported each month (the monthly count); (3) the number of cases as proportion of total cases for all diseases (either avian or herpetological diseases); (4) the number of cases as proportion of total cases for all diseases in a State; and (5) the proportion of cases for each disease by taxonomic grouping.

Annual counts were calculated by summing the total number of cases in a year for each year from 2001 to 2010, and monthly counts were calculated by summing the total number of cases in each month pooled across years. For avian diseases, the number of cases as a proportion of total cases was calculated by summing the total number of avian cases for each of the eight diseases included in this report for each year, and then dividing the total number of cases for a particular avian disease by the total for all avian diseases. The equivalent was done for the herpetological diseases, ranavirus and chytridiomycosis. For the proportion by State, the total number of cases in each state was summed separately for avian diseases (the eight included in the report) and herpetological diseases (ranavirus and chytridiomycosis), and then the number of cases for each disease was divided by the total number of avian or herpetological cases in the State.
Lastly, we report the proportion of cases of an individual disease that included at least one member of a particular taxonomic group. For avian diseases we have grouped species by taxonomic order: Anseriformes (ducks, geese, swans), Charadriiformes (shorebirds, gulls, terns), Ciconiiformes (herons, egrets), Columbiformes (doves, pigeons), Falconiformes (hawks, eagles, falcons), Galliformes (upland game birds), Gaviiformes (loons), Passeriformes (songirds), Pelecaniformes (pelicans, cormorants), Gruiformes (cranes, rails, coots), Podicipediformes (grebes), and Strigiformes (owls). For herpetological diseases we categorized specimens as frog, tree frog, toad, salamander and newt, and turtle. Each case could be included more than once in this summary, if the case contained specimens from more than one taxonomic group. In other words, the sum of the proportions of cases in each taxonomic group for one disease could exceed 100 percent.

Voluntary case submissions constitute a passive sampling technique, and the NWHC has no quantitative measure of survey effort. Therefore, we exercise caution in interpreting fluctuations in the number of cases submitted as an index of temporal or spatial trends in the incidence of a disease. Many unmeasured factors - changes in the number of field personnel or the amount of funding, changes in the detection probability of the carcasses (increased or decreased predation, for example), and the acquisition or loss of local diagnostic experts - can result in a change in submission rates to the NWHC. Furthermore, additional cases were likely submitted to State or regional diagnostic laboratories for evaluation and would not be included in this report. Thus, we report raw data with minimal interpretation to provide information on where, when, and in what species particular diseases have been detected in NWHC submissions. We believe these data, combined with other sources of information, may generate testable hypotheses regarding disease status and trends and provide a launching point toward the better understanding of the ecology of wildlife diseases. The data used in this report can be found in the appendix. 


\section{Selected Wildlife Diseases}

\section{Avian Diseases}

\section{Botulism Type C}

\section{Cause or Etiology}

Botulism type $\mathrm{C}$ is an intoxication by a natural toxin produced by the bacterium, Clostridium botulinum. This anaerobic bacterium produces multiple types of botulinum toxins that are referred to as types A through G. To date, only botulinum toxins types $\mathrm{C}$ and $\mathrm{E}$ are known to cause morbidity and mass mortality events in wild birds in the United States. In birds, botulism type $\mathrm{C}$ is caused by ingestion of the toxin from the environment, and is usually associated with ingestion of invertebrates in and adjacent to rotting piles of vegetation (usually in or adjacent to ponds, lakes, or shallow wetlands) or by ingestion of one or more maggots from rotting carcasses. Unlike cases of botulism in humans and livestock, cases of botulism associated with anaerobic growth of the bacterium in the intestine or wounds are not documented or are very rare in birds.

\section{Host Species and Annual Distribution}

Botulism type $\mathrm{C}$ affects and kills a much greater taxonomic range of birds that botulism type E. Waterfowl such as ducks, geese, and swans most often are involved

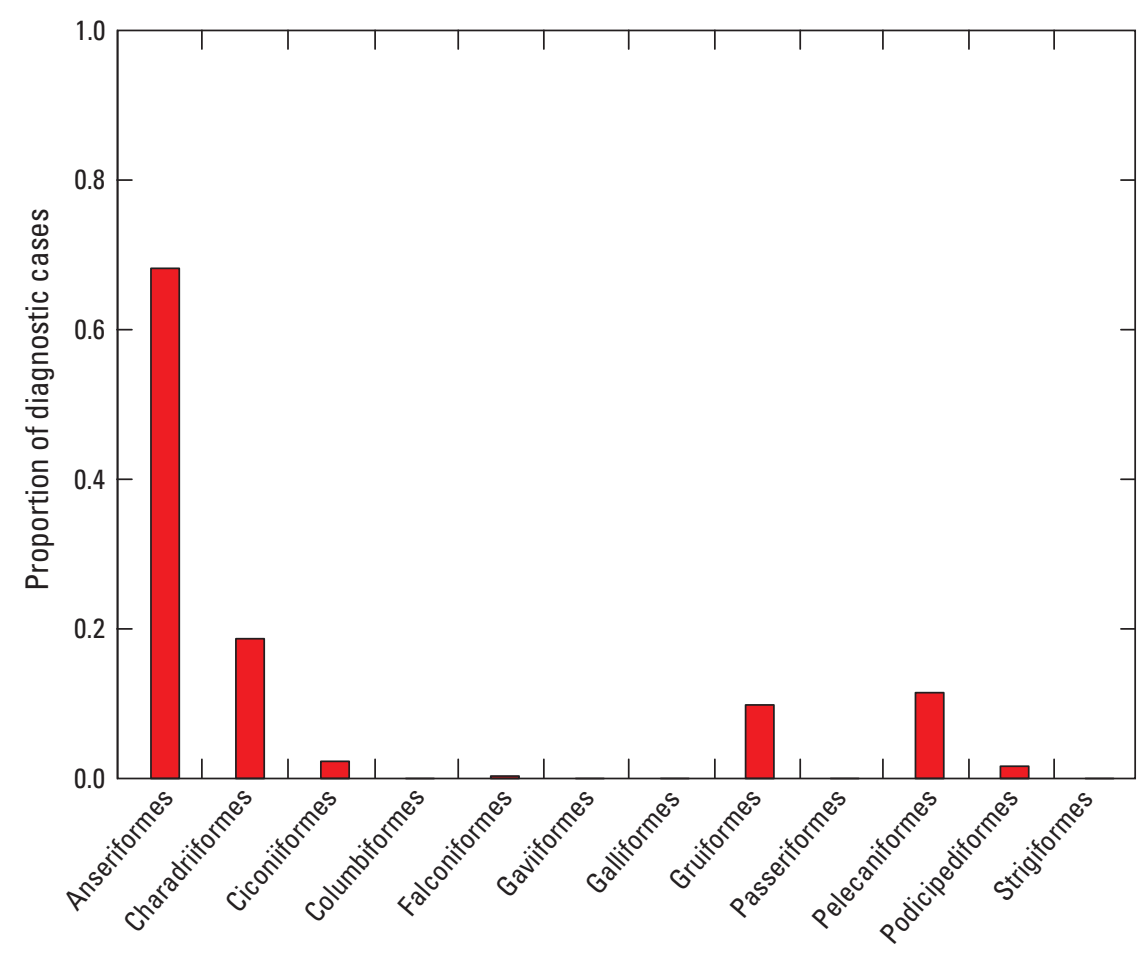

Taxomonic order (fig. 1), but gulls, terns, pelicans, egrets, ibises, herons, stilts, coots, sandpipers, sanderlings, and plovers also have been test-positive for botulism type C. Infrequently, botulism is confirmed in yellowlegs, godwits, avocets, and turnstones. A diagnosis of botulism of any type is difficult in small shore birds and most passerines, because of their small body size and the difficulty in collecting a volume of blood sufficient for the diagnostic test. Often, blood samples are pooled from multiple small birds of the same species from the same event for a single test. The taxa of birds in which botulism has been observed prior to 2001, but was not confirmed in 2001-10, are raptors, owls, pigeons, doves, quail, pheasants, grouse, and most songbirds.

\section{Geographic Distribution}

Die-offs due to botulism type $\mathrm{C}$ between 2001 and 2010 were documented in 29 States, Puerto Rico, and the Pacific Islands of Laysan and Palau (fig. 2). Mortality events due to botulism type $\mathrm{C}$ have involved endangered species, including Hawai'ian stilts (black-necked stilt or Ae'o; Himantopus mexicanus knudseni), Laysan ducks (Laysan teal; Anas laysanensis), Hawai'ian coot ('Alae Ke'oke'o; Fulica americana alai), Hawai'ian duck (Koloa Maoli; Anas wyvilliana) and others. Distribution of botulism type $\mathrm{C}$ remains similar to previously reported cases (Rocke and Friend, 1999).

\section{Seasonality}

Botulism type $\mathrm{C}$ has a clear seasonality with most cases occurring during summer months and peaking in August in temperate regions. In southern States, cases may occur every month of the year, but rarely at times when snow covers the ground or ice covers wetlands. The onset of cases is usually in late June, and the number of mortality events increases steadily in July and August (fig. 3). The number of annual mortality events peaked in 2006 (fig. 4) at 49 cases and has declined steadily since, but the number of cases increased slightly in 2009.

Figure 1. Occurrence of botulism type $C$ in wild birds 2001-10, by order. 
A. 2001-5

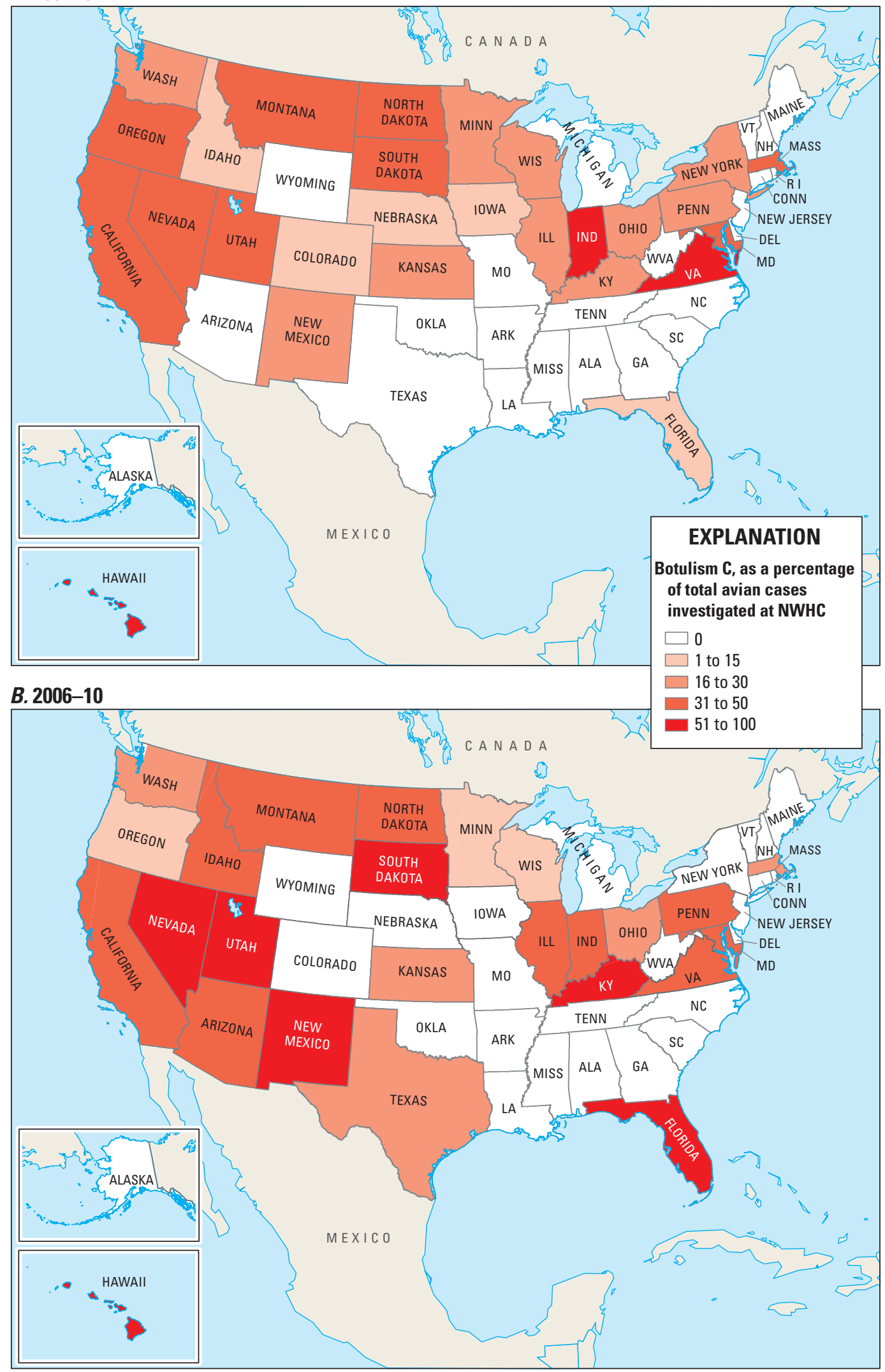

Signs and Lesions

Field observations usually begin with the appearance of numerous carcasses along a shoreline and with fewer sick birds. The signs of botulism types $\mathrm{C}$ and $\mathrm{E}$ are indistinguishable, and they include lethargy, reluctance to fly or swim, limb and neck paralysis, and paralysis of the third eyelids. Birds found dead on open water may have had neck paralysis sufficient to prevent the head from being immersed in water; these birds may have internal abnormalities consistent with drowning. Botulism typically is lethal to birds within hours; so many birds are in fair to good body condition and without obvious internal abnormalities. Occasionally, ingested maggots may be found in the lumen of the distal esophagus, proventriculus, or gizzard; ingested maggots, when tested, usually are heavily laden with botulinum toxin(s).

Figure 2. Prevalence of botulism $C$ diagnosed in wild bird disease outbreaks, as a percentage of all wild bird disease outbreaks, by State, for $A, 2001-5$ and $B, 2006-10$. 


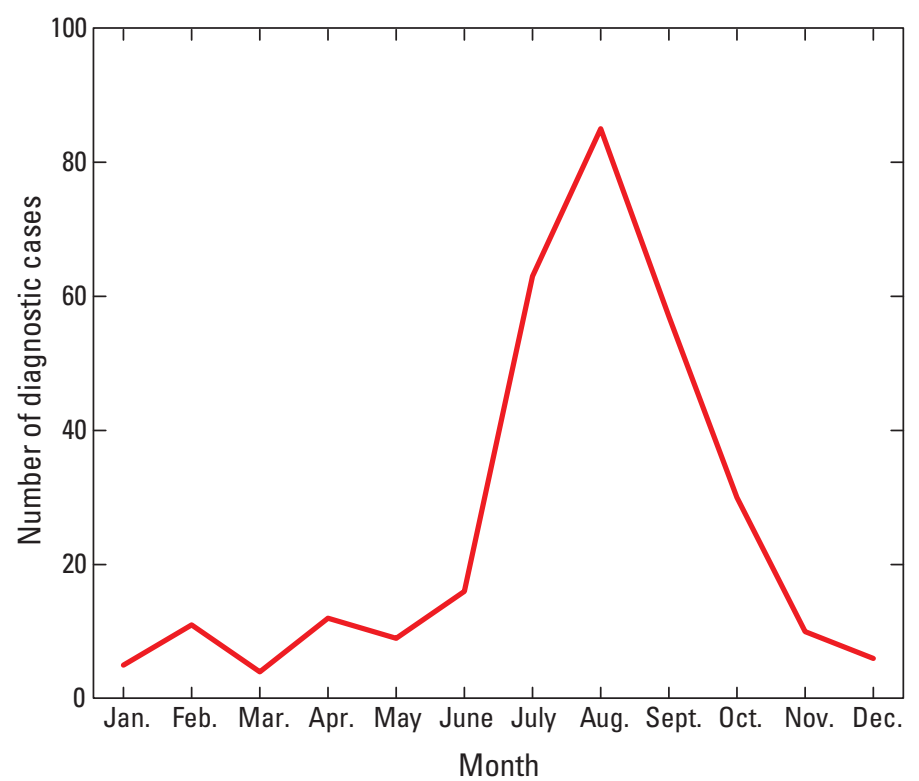

Figure 3. Monthly number of cases of botulism type $C$ in wild birds.

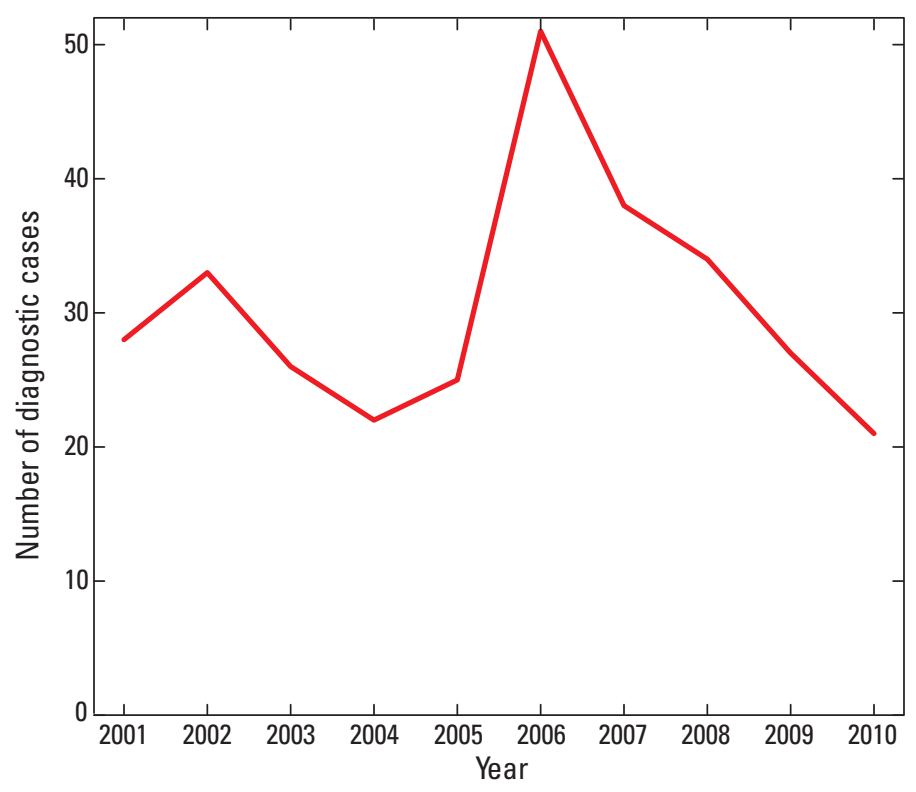

Figure 4. Annual number of cases of botulism type $C$ in wild birds.

\section{Significance and Zoonotic Risk}

Botulism type $\mathrm{C}$ may affect a variety of wildlife and domestic animals, but type $\mathrm{C}$ is much less hazardous to humans than type E. Although animals that prey on sick birds with botulism or scavenge on their carcasses may contract secondary botulism, this is rarely documented; however, in 2006 - the year of the peak number of botulism type $C$ cases (49) - three dogs that were trained and working as retrievers of waterfowl were diagnosed with botulism type C. One dog was used by a biologist to retrieve carcasses of waterfowl during confirmed die-offs due to botulism type $\mathrm{C}$, and another dog was used as a retriever by duck hunters at a site where botulism had occurred. All three dogs became partially paralyzed and then recovered after a week of intensive veterinary clinical care. Because carcasses may provide suitable anaerobic growth media for Clostridium botulinum and become infested with toxin-laden maggots, these maggot-infested carcasses become the source of additional cases of botulism when birds feed on maggots. Smaller invertebrates that feed on botulinumladen carcasses may be the source of botulism for shore birds such as plovers, sanderlings, and sandpipers.

\section{Selected References}

Rocke, T.E., and Bollinger, T.K., 2007, Avian botulism, chap. 21 of Thomas, N.J., Hunter, D.B., and Atkinson, C.T., eds., Infectious diseases of wild birds: Ames, Iowa, Blackwell Publishing, p. 377-416.

Rocke, T.E., and Friend, M., 2009, Avian botulism, chap. 38 of Friend, M., and Franson, J.C., eds., Field manual of wildlife diseases: general field procedures and diseases of birds: U.S. Geological Survey Information and Technology Report 1999-001, p. 271-281. 


\section{Botulism Type $\mathrm{E}$}

\section{Cause or Etiology}

Botulism type $\mathrm{E}$ is intoxication by a natural toxin produced by the bacterium, Clostridium botulinum. This anaerobic bacterium produces multiple types of botulinum toxins that are referred to as types A through G. To date, only botulinum toxins types $\mathrm{C}$ and $\mathrm{E}$ are known to cause morbidity and massive mortality events in wild birds in the United States. Botulinum toxins A, B, E, and, rarely, F are usually implicated in human cases of botulism. In birds, the disease, botulism, is caused by ingestion of the toxin from the environment and usually is associated with ingestion of fish with botulism, ingestion of invertebrates in and adjacent to rotting piles of vegetation (usually in or adjacent to ponds, lakes, or shallow wetlands), or by ingestion of one or more maggots from rotting carcasses. Unlike cases of botulism in humans and livestock, cases of botulism associated with anaerobic growth of the bacterium in the intestine or wounds are not documented or are very rare in birds.

\section{Host Species and Annual Distribution}

Botulism type E affects many more fish-eating species of birds than botulism type C (fig. 5). During the period of 2001-5, this disease was reported predominantly along the shorelines of the Great Lakes (fig. 6A), and 8 of 10 mortality events involved loons, cormorants, pelicans, or gulls. A single common loon (Gavia immer) from Maine was detected with botulism type $\mathrm{E}$ in 2005. American coots (Fulica americana) and multiple species of ducks were affected in 2 of 10 other mortality events. During 2006-10, mortality events due to botulism type $\mathrm{E}$ were an annual occurrence on the shores of the Great Lakes, but additional cases were detected in the Western States of North Dakota, Montana, and Idaho (fig. 6B). At present, it is unclear whether botulism type $\mathrm{E}$ is spreading westward or simply was not detected in the three Western States until 2009 and 2010. In the years 2006-10, affected species again were mostly fish-eating birds; and grebes, terns, sandpipers, and plovers were affected in significant numbers in addition to the loons, cormorants, pelicans, and gulls affected during 2001-5. Seven mortality events during 2001-5 and 18 during 2006-10 were attributed to botulism type E. It is not clear whether increasing events are due to increased awareness and surveillance for this disease or other unknown factor(s). The seasonality and possible host cycles of botulism type $\mathrm{E}$ are being studied extensively.

\section{Geographic Distribution}

Botulism type E occurs predominantly in States and Canadian Provinces that border the five Great Lakes (fig. 6A). Only five mortality events have occurred since 2005 in States not bordering the Great Lakes: Maine, North Dakota with two mortality events, Montana, and Idaho (fig. 6B).

\section{Seasonality}

The vast majority of mortality events due to botulism type E occur between June and November annually (fig. 7). Mortality events tend to peak yearly in the months of July and October. Cases of all types of botulism peak during the summer and autumn months and are infrequent during winter and spring months (fig. 8).

\section{Signs and Lesions}

Field signs of botulism type E are indistinguishable from those of botulism type $\mathrm{C}$ (see the previous section on botulism type $\mathrm{C}$ ), but field signs usually involve the appearance of dead fisheating birds along lake shores. Many of these birds are presumed to have ingested fish affected by botulism in open water, and after death, the carcasses wash ashore. The contents of the esophagus, crop, proventriculus, and ventriculus (gizzard) generally are not helpful in making a presumptive diagnosis of botulism, because, at present, it is not clear which species of fish may be more or less resistant to botulism.

Figure 5. Occurrence of botulism type $E$ in wild birds 2001-10, by order. 


\section{A. 2001-5}

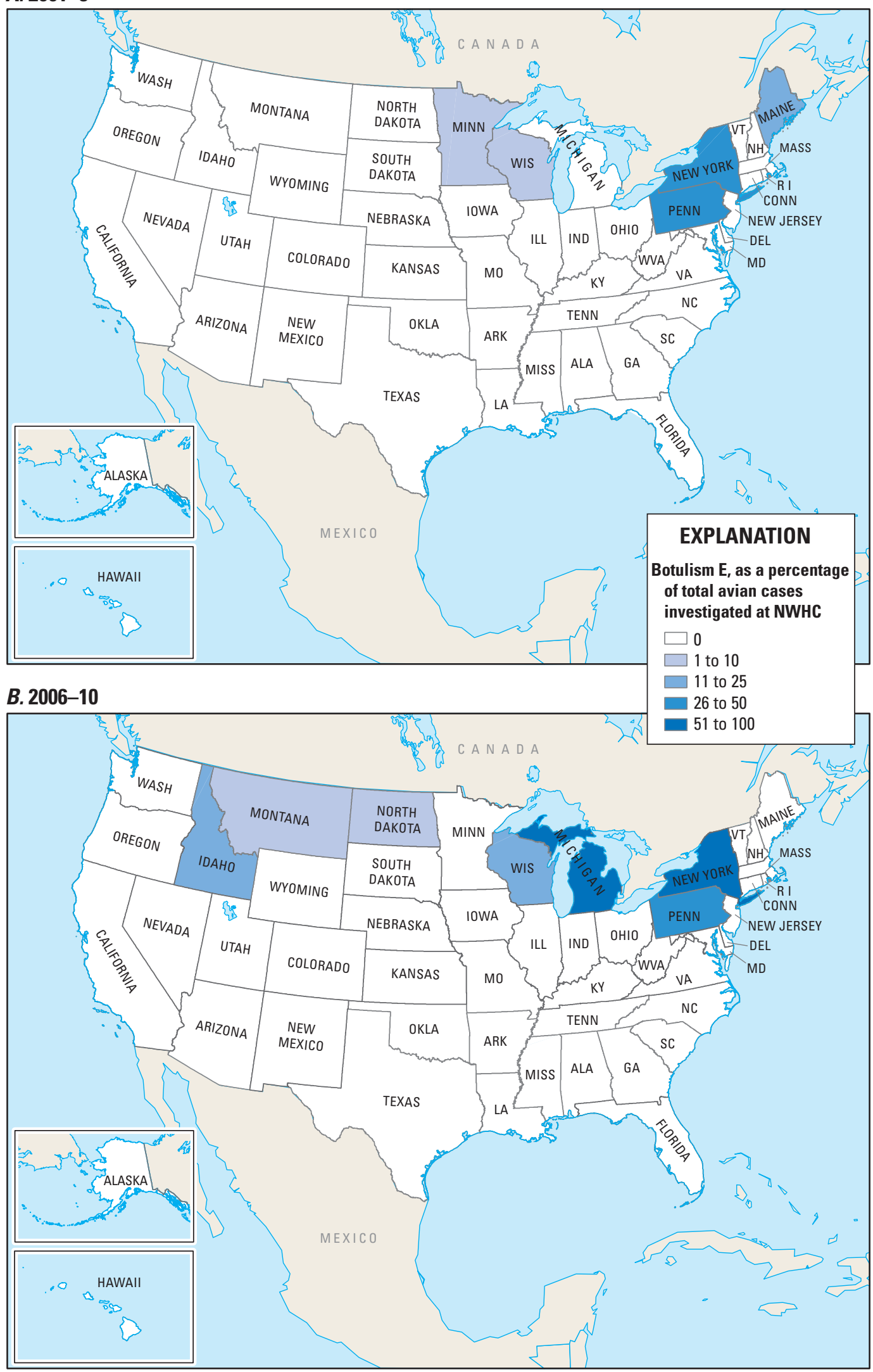

Figure 6. Prevalence of botulism E diagnosed in wild bird disease outbreaks, as a percentage of all wild bird disease outbreaks, by State, for $A, 2001-5$ and $B, 2006-10$. 


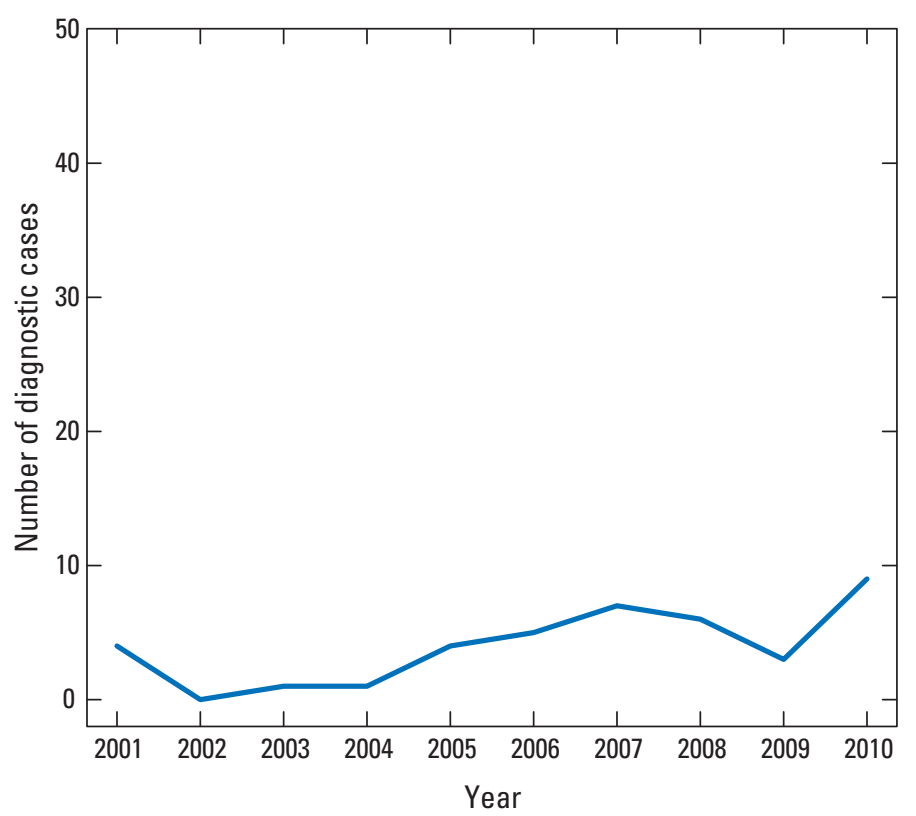

Figure 7. Annual number of cases of botulism type $E$ in wild birds.

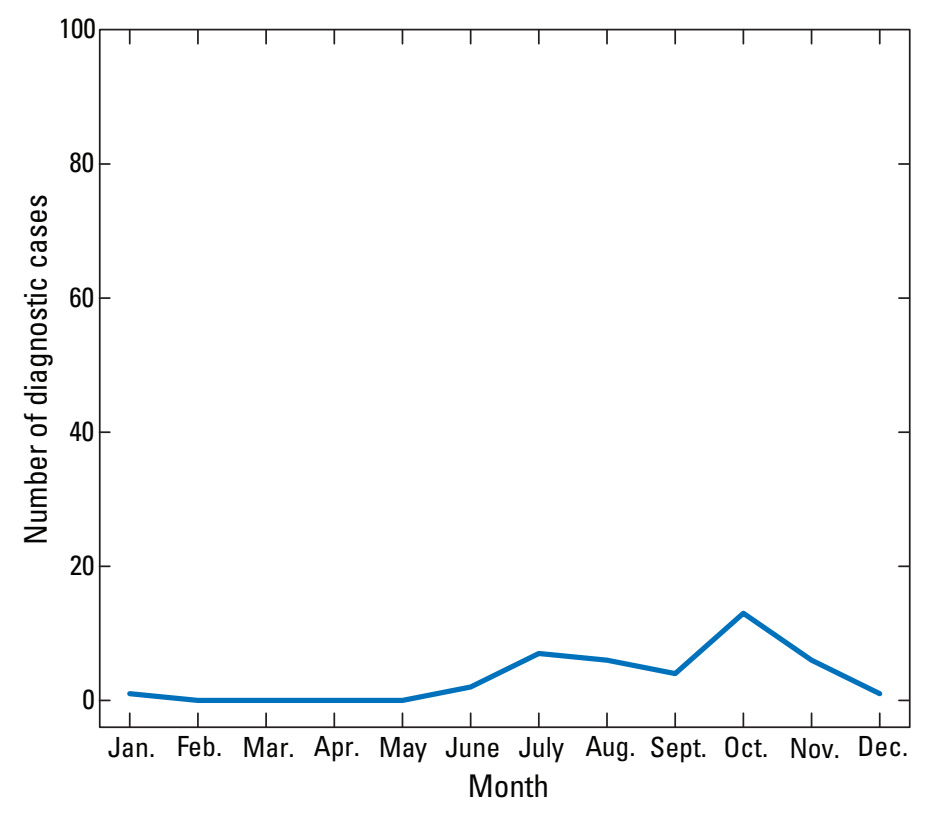

Figure 8. Monthly number of cases of botulism type $E$ in wild birds.

\section{Significance and Zoonotic Risk}

Botulism type $\mathrm{E}$ is an important zoonosis, and immediately following confirmation of the disease (by mouse protection tests) it is a reportable disease to the Centers for Disease Control (CDC) Select Agent Program. This requirement also applies to Botulism Type C. Humans may be sickened or killed by botulism type E, so blood, tissues, and carcasses of birds suspected to have type E poisoning should be handled with personal protection equipment ("PPE"; that is, gloves, particulate masks, or respirators, and so forth). Domestic animals, including dogs, are susceptible to botulism, and there are cases of dogs that retrieve carcasses of dead birds subsequently developing botulism. Thus, dogs should not be used when collecting sick and dead birds suspected of having botulism. Management of disease outbreaks involves daily or twice daily collection of fish and bird carcasses to interrupt the carcass-maggot (or carcass-invertebrate) cycle of botulism.

\section{Selected References}

Lafrancois, B.M., Riley, S.C., Blehert, D.S., and Ballmann, A.E., 2011, Links between type E botulism outbreaks, lake levels and surface water temperatures in Lake Michigan, 1963-2008: Journal of Great Lakes Research v. 37, p. 86-91.

Perez-Fuentetaja, A., Clapsadl, M.D., Getchell, R.G., Bowser, P.R., and Lee, W.T., 2011, Clostridium botulinum type E in Lake Erie: Inter-annual difference and role of benthic invertebrates: Journal of Great Lakes Research, v. 37, no. 2, p. 238-244, http://dx.doi.org/10.1016/jglr.2011.03.013. 


\section{Avian Cholera}

\section{Cause or Etiology}

Avian cholera (avian pasteurellosis, fowl cholera) is a contagious infectious disease of many species of birds caused by the bacterium Pasteurella multocida. Avian cholera is not related to the bacterium and toxins that cause human cholera. Domestic and wild birds can be infected by many serotypes of $P$. multocida, but the predominant serotype in wild birds in the U.S. is serotype 1. Serotypes 3 and 4 occur occasionally in massive mortality events on the East Coast, but they were not observed during the 10 years of this report. Serotypes of P. multocida isolated from infected birds in Hawai'i (data not shown on maps and figures) tend to have uncommon serotypes and mixtures of serotypes such as serotypes 8,12 , and others. The bacterium is probably transmitted when birds ingest the organism from contaminated aquatic environments during seasons when birds are crowded. The bacterium may also be transmitted bird-to-bird and by aerosol. Studies by NWHC scientists (Samuel and others, 2005) have provided evidence that up to 2 percent of normal-appearing lesser snow (Chen caerulescens) and Ross's geese (Chen rossii) are carriers of pathogenic serotypes of avian cholera. Many mortality events due to avian cholera are associated with seasonal migratory appearance of these geese in the Mississippi, Central, and Pacific Flyways.

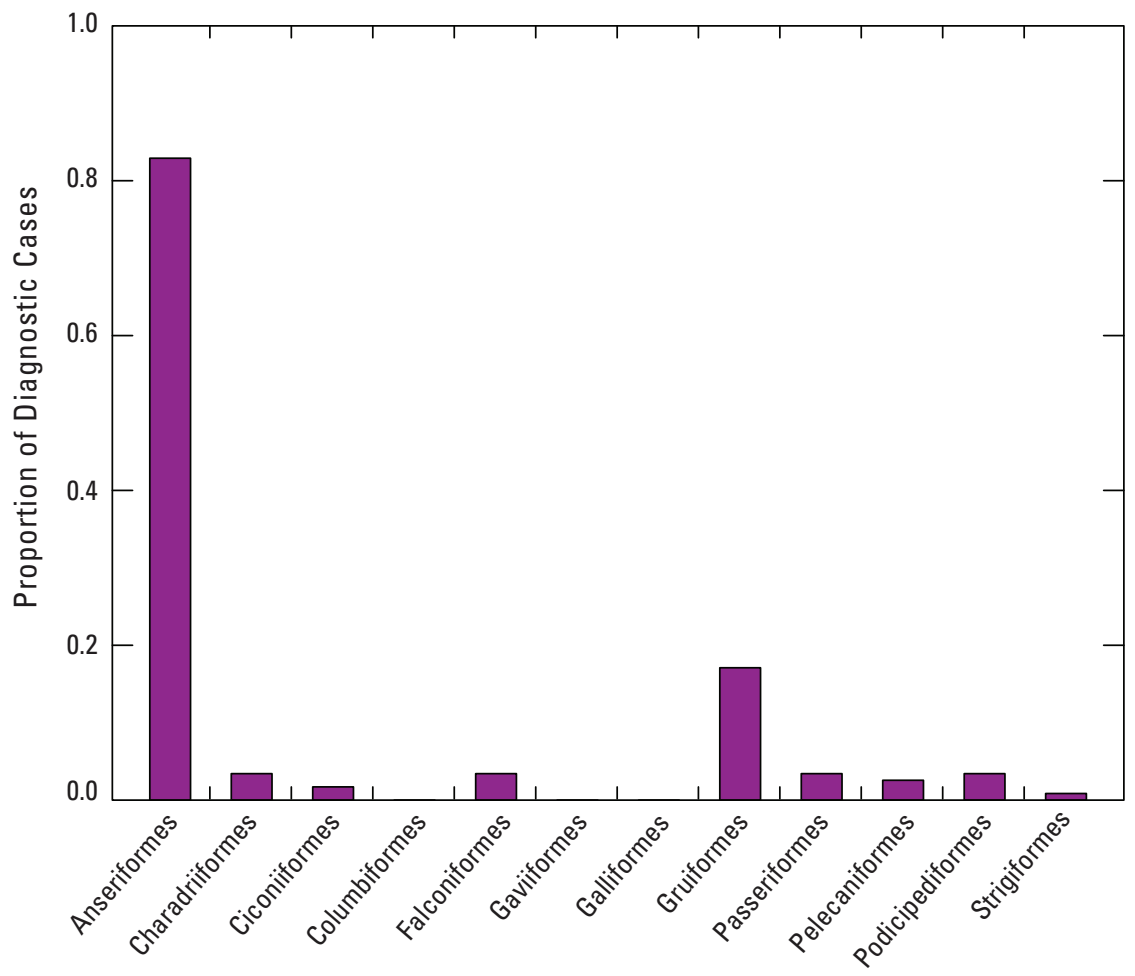

Taxonomic order

\section{Host Species}

It is probable that most species of birds are susceptible to infection by Pasteurella multocida, but mortality events predominantly involve waterfowl and shorebirds (fig. 9). The vast majority of birds dying with avian cholera are ducks, geese, swans, grebes, and coots, with lesser numbers of gulls. Small mortality events involving only $1-3$ birds during 2001-10 occurred in bald eagles (Haliaeetus leucocephalus), a red-tailed hawk (Buteo jamaicensis), a long-eared owl (Asio otus), black-necked stilts (Himantopus mexicanus), killdeer (Charadrius vociferous), cormorants, common ravens (Corvus corax), and other passerines.

\section{Geographic Distribution}

All but three mortality events in 2001-10 were in States west of the Mississippi River in the Mississippi, Central, and Pacific Flyways (figs. $10 A$ and $B$ ). In 2008, avian cholera was documented for the first time in Arkansas in lesser snow and Ross's geese and ducks; but avian cholera had been detected for decades in States north, south, and west of Arkansas. From 2001 to 2010, avian cholera was not detected in five Western States (Washington, Nevada, New Mexico, Colorado, and Montana) where it was regularly documented in the years prior to this report, and it was not detected in three northern Atlantic Coastal states (Maine, Maryland, and Virginia).

The vast majority of serotypes involved in western mortality events were type 1 , but data for much of 2001-5 are incomplete and comparison to the second 5-year period (2006-10) is not possible (figs. $10 A$ and $B$ ). Most avian cholera events were in freshwater and estuarine environments, but several States of the Great Plains and Great Basin have numerous saline and hypersaline lakes (and "potholes") where mortality events due to avian cholera are frequent. Mortality events in three States east of the Mississippi River (Florida, Illinois, and Mississippi) involved lesser snow and Ross's geese and a coot; it is suspected that populations of lesser snow and Ross's geese are increasing, and overwintering populations may be expanding their winter ranges eastward. Data for avian cholera events in Hawai'i and Pacific Islands are incomplete.

Figure 9. Occurrence of avian cholera in wild birds, 2001-10, by order. 


\section{A. 2001-5}

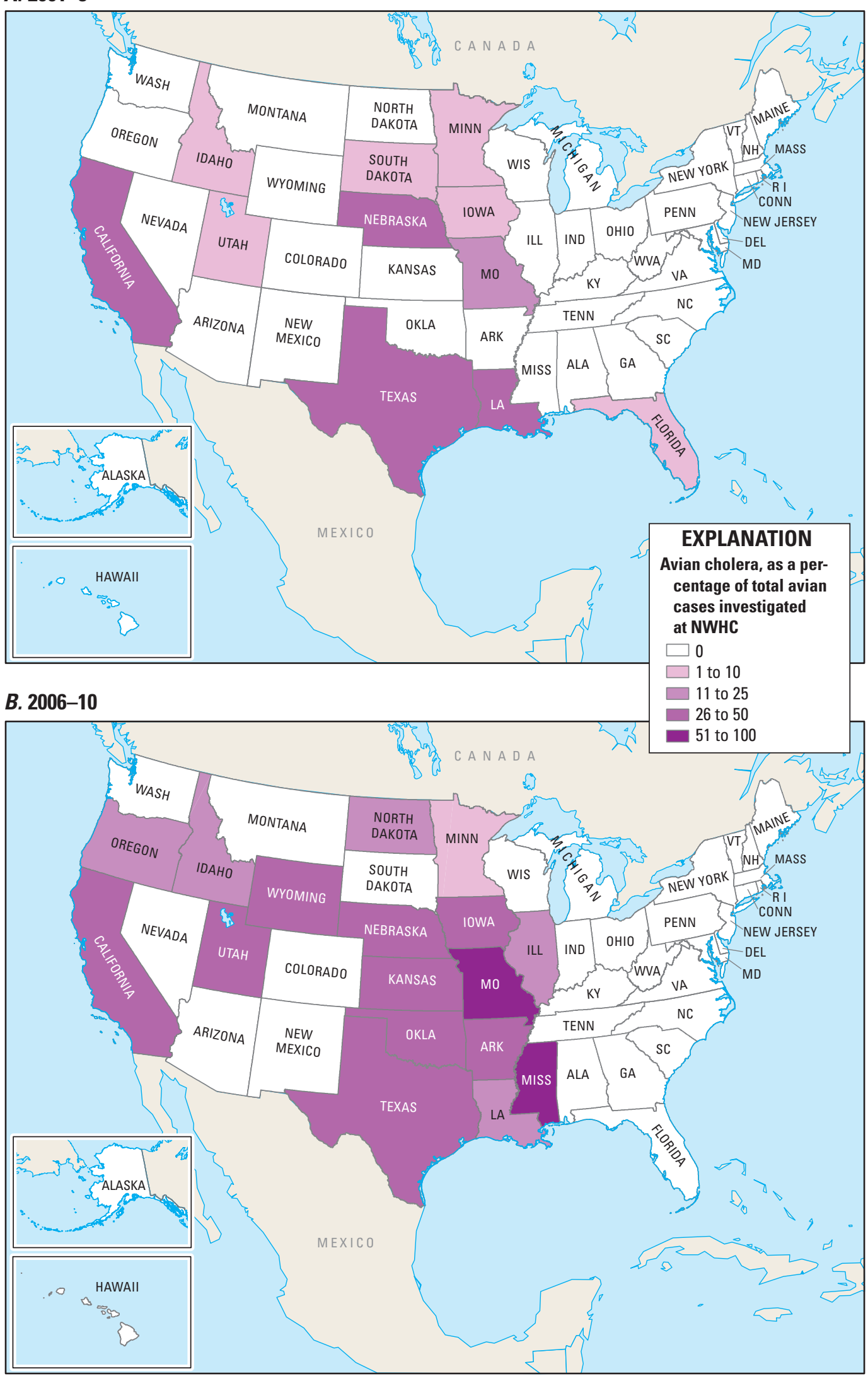

Figure 10. Prevalence of avian cholera diagnosed in wild bird disease outbreaks, as a percentage of all wild bird disease outbreaks, by State, for $A, 2001-5$ and $B, 2006-10$. 


\section{Seasonality}

Most mortality events due to avian cholera occur during winter months of November through March (fig. 12) on wintering grounds during periods of waterfowl and shorebird crowding. Cases of avian cholera occur in every month of the year, but casualty numbers during late spring, summer, and early autumn usually number in the dozens, although those during winter months involve hundreds or thousands of birds.

\section{Signs and Lesions}

Avian cholera is consistently a rapidly lethal systemic infection of wild birds. Most birds die in 8-48 hours following exposure. Consequently, most dead birds will be in fair to good body condition. Field and clinical signs in live birds are varied and attributed to bacterial septicemia. Signs include lethargy, weakness, reluctance to fly, walk, or swim, and occasionally, clear or muco-purulent nasal and oral discharges. Some birds may present with neurological signs. Sick birds often die within minutes of being collected or handled. At necropsy, the characteristic finding is minute white foci of necrosis in the liver (and occasionally the spleen), but white foci in the liver may occur with other infectious diseases such as salmonellosis and erysipelas. Another common abnormality is a thick, tenacious, yellow muco-purulent material within the small intestine. Petechial hemorrhages on the heart, liver, and other serosal surfaces may be present.

\section{Significance and Zoonotic Risk}

Avian cholera is considered a low risk to humans because of differences in species susceptibility to the many serotypes of $P$. multocida. Birds and mammals may be infected by $P$. multocida through wounds from the bites of predators (especially cats); therefore, persons handling dead birds should wear gloves to prevent secondary infections of minor skin wounds and abrasions. When handling large numbers of carcasses and disposing of them by burying or burning, there is a significant possibility of aerosol transmission of the bacterium, especially in confined spaces; persons should wear masks (particle respirators) when handling numerous avian carcasses. Carcasses should be disposed by methods that make them unavailable to susceptible scavengers such as mice, crows, gulls, and eagles.

\section{Selected References}

Samuel, M.D., Botzler, R.G., and Wobeser, G.A., 2007, Avian cholera, in Thomas, N.J., Hunter, D.B., and Atkinson, C.T., eds., Infectious diseases of wild birds: Ames, Iowa, Blackwell Publishing, p. 239-269.

Samuel, M.D., Shadduck, D.J., Goldberg, D.R., and Johnson, W.P., 2005, Avian cholera in waterfowl: The role of Lesser Snow and Ross's geese as disease carriers in the Playa Lakes Region: Journal of Wildlife Diseases, v. 41, no. 1, p. 48-57.

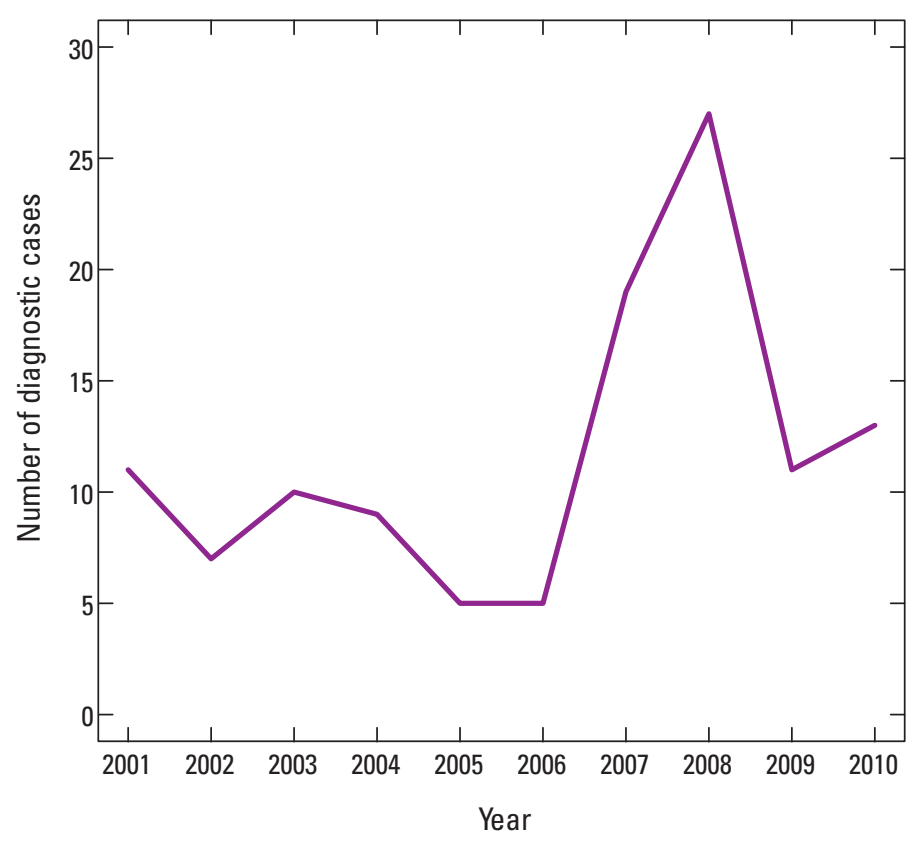

Figure 11. Annual number cases of avian cholera in wild birds.

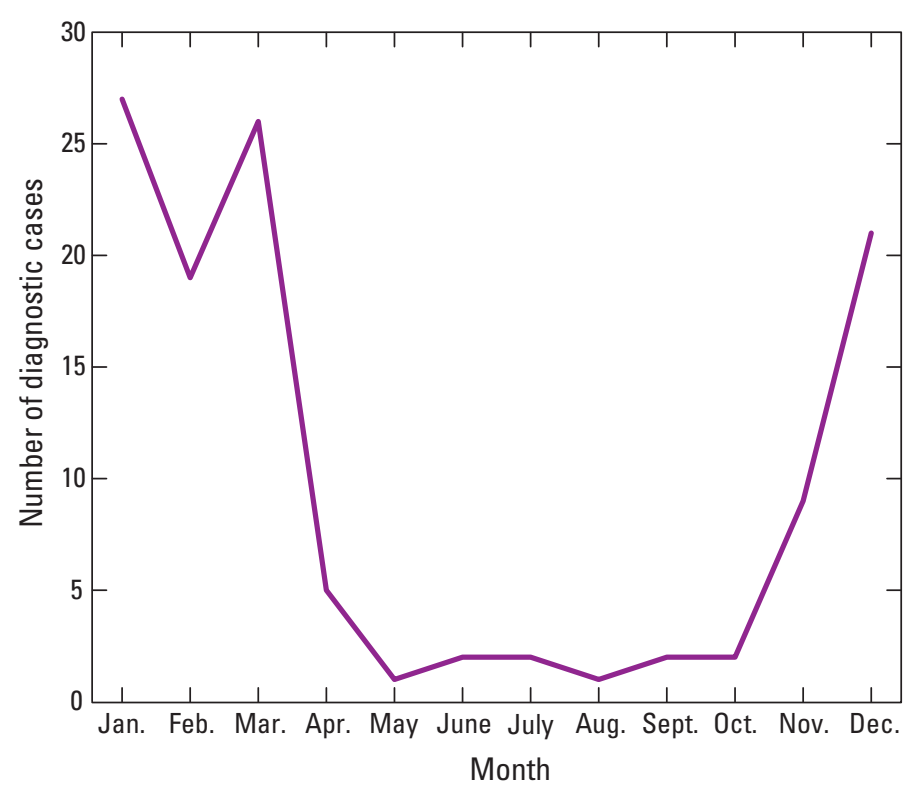

Figure 12. Monthly number cases of avian cholera in wild birds. 


\section{Salmonellosis}

\section{Cause or Etiology}

Salmonella bacteria are a fairly common cause of systemic lethal infections in songbirds (passerines) in the U.S., and many cases are associated with specific backyard birdfeeding stations. The vast majority of cases of salmonellosis in passerine birds linked to backyard birdfeeders are due to Salmonella typhimurium.

\section{Host Species and Annual Distribution}

About half of all cases of salmonellosis are in passerines associated with bird-feeding stations (fig. 13). Affected species include pine siskins (Carduelis pinus), common redpolls (Carduelis flammea), American goldfinches (Carduelis tristis), house sparrows (Passer domesticus), crossbills (Loxia spp.), grosbeaks, cowbirds, and various species of finches. Mortality events also occur regularly during nesting season in colonynesting birds such as common terns (Sterna hirundo), doublecrested cormorants (Phalacrocorax auritus), cattle egrets (Bubulcus ibis), herons, pelicans, and gulls. Infrequently, infections are detected in doves, hawks, and grebes. There were no cases of Salmonella pullorum in wild gamebirds (gallinaceous birds) from 2001 to 2010. Salmonella spp. are isolated frequently from only the intestine (colon or cloaca) of birds and reptiles, but these limited infections are not included with these systemic lethal infections. One trend may have emerged in 2001-10 for pelicans and cormorants. Salmonellosis in these colony-nesting birds was considered "infrequent"

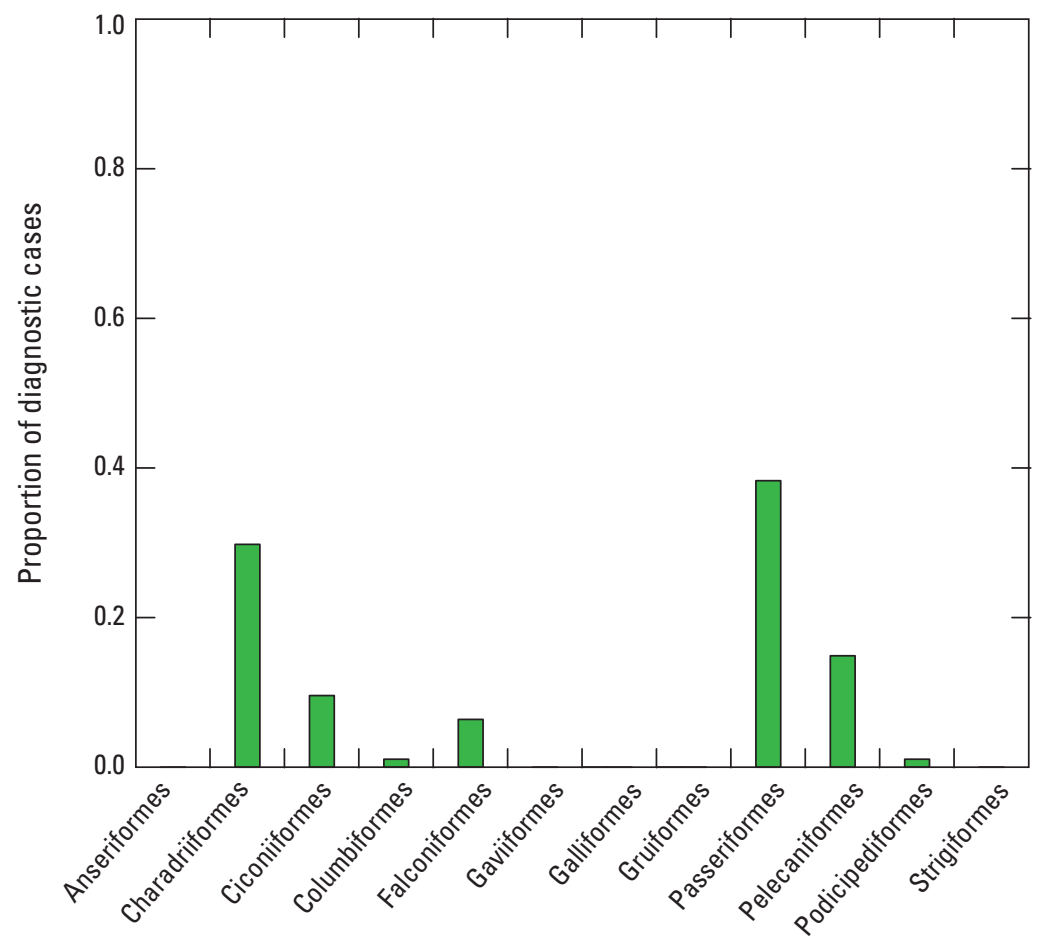

(Friend, 1999), but with increased monitoring of colonynesting birds for virulent Newcastle Disease virus (vNDV) and West Nile virus, salmonellosis must now be considered a common cause of mortality in these birds.

\section{Geographic Distribution}

Salmonellosis occurs nationwide (fig. 14) and is considered a global zoonosis.

\section{Seasonality}

Salmonellosis has two trends: cases among songbirds during winter months that are associated with backyard feeding stations and cases among shorebirds such as gulls, cormorants, and terns at nesting sites during nesting season (fig. 16). The number of cases of salmonellosis in colony-nesting birds increases greatly during summer months. The number of cases during winter months in songbirds and in pigeons and doves (Columbiformes) that frequent garden birdfeeders probably is significantly underreported.

\section{Signs and Lesions}

Passerine birds with salmonellosis usually present as lethargic and emaciated. Bacterial caseous granulomas are most commonly detected in the esophagus and crop; these granulomas often are large enough to be palpable in the live bird or intact carcass. Granulomas in passerines also are found in the intestine, cloaca, liver, and spleen. Granulomas in the liver and spleen often are pinpoint-sized yellow foci. Salmonella infections in shorebirds such as gulls, terns, cormorants, egrets, herons, and pelicans may present as acute systemic infections, and the affected birds may appear well-nourished and have minimal external and internal abnormalities. Salmonellosis in shorebirds may also present as subacute to chronic infections, and the birds are emaciated. Caseous granulomas in the esophagus and crop are not a feature of systemic salmonellosis of shorebirds.

Figure 13. Occurrence of salmonellosis in wild birds $2001-10$, by order. 
A. 2001-5

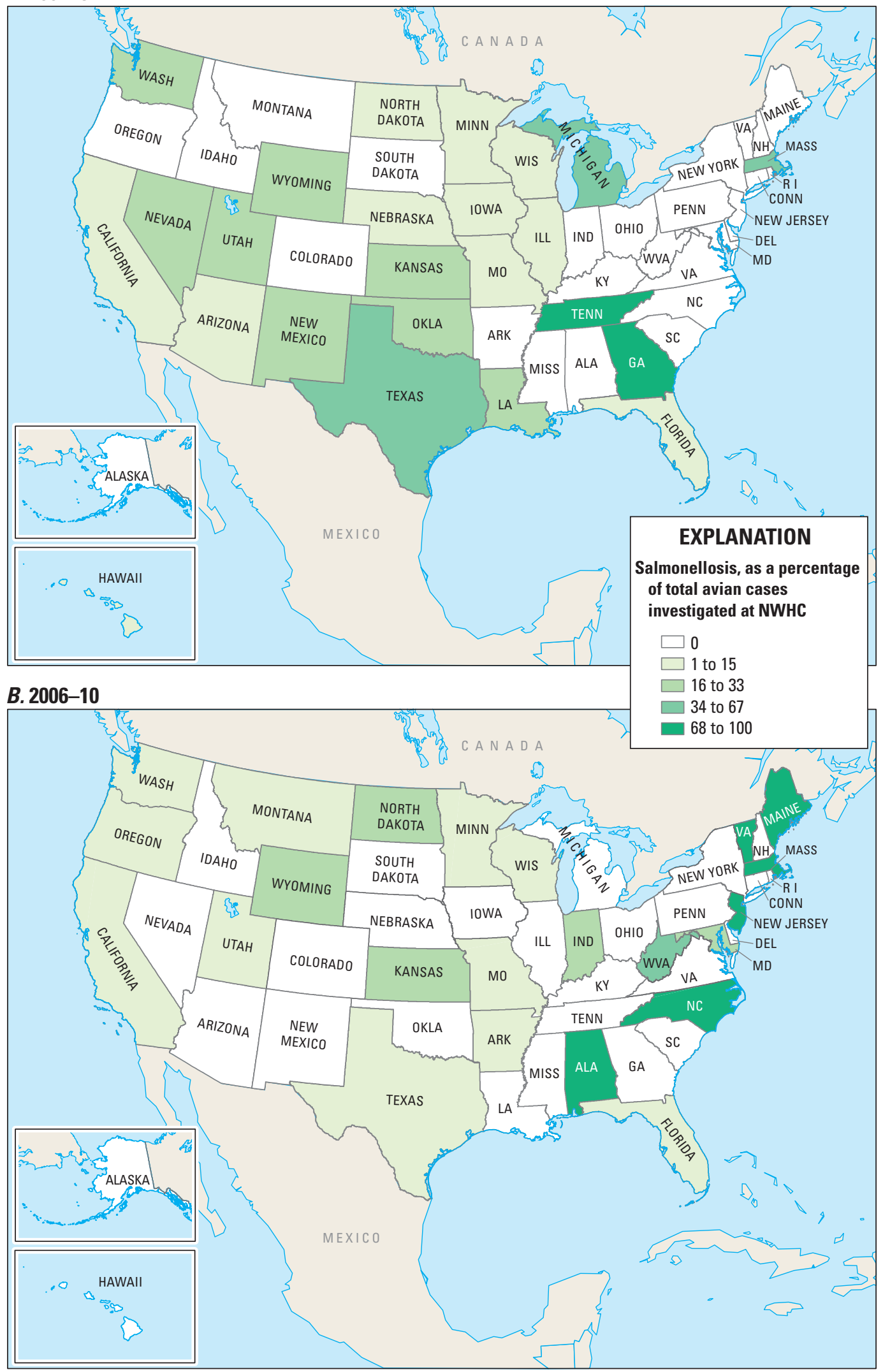

Figure 14. Prevalence of salmonellosis diagnosed in wild bird disease outbreaks, as a percentage of all wild bird disease outbreaks, by State, for $A, 2001-5$ and $B, 2006-10$. 


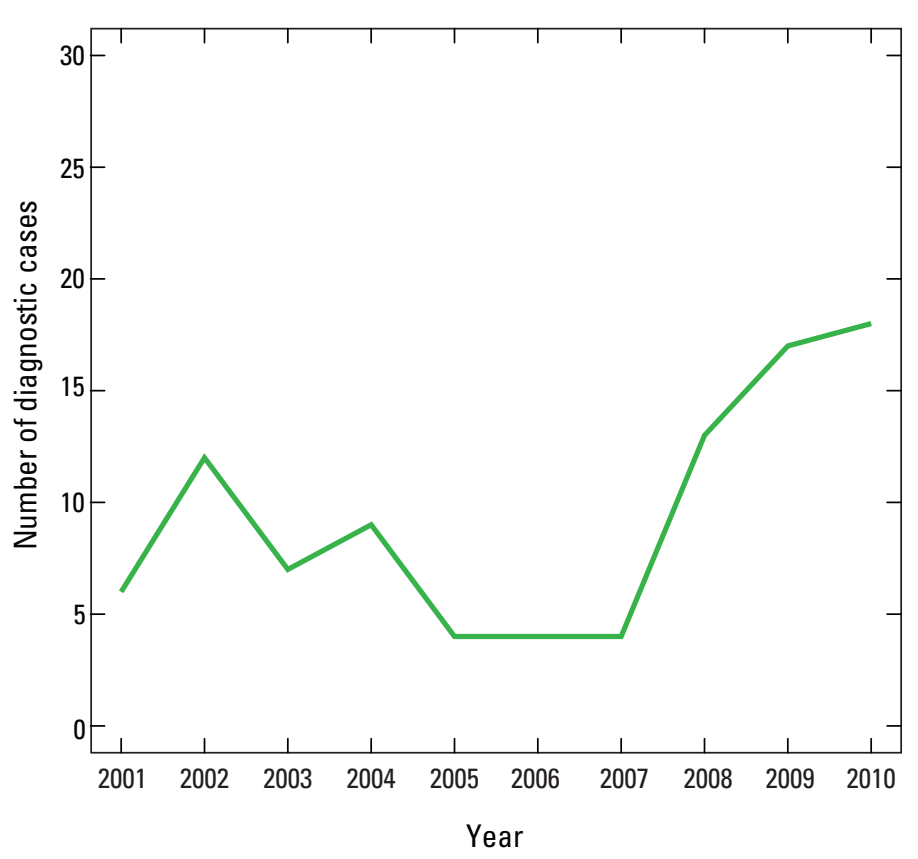

Figure 15. Annual number of cases of salmonellosis in wild birds.

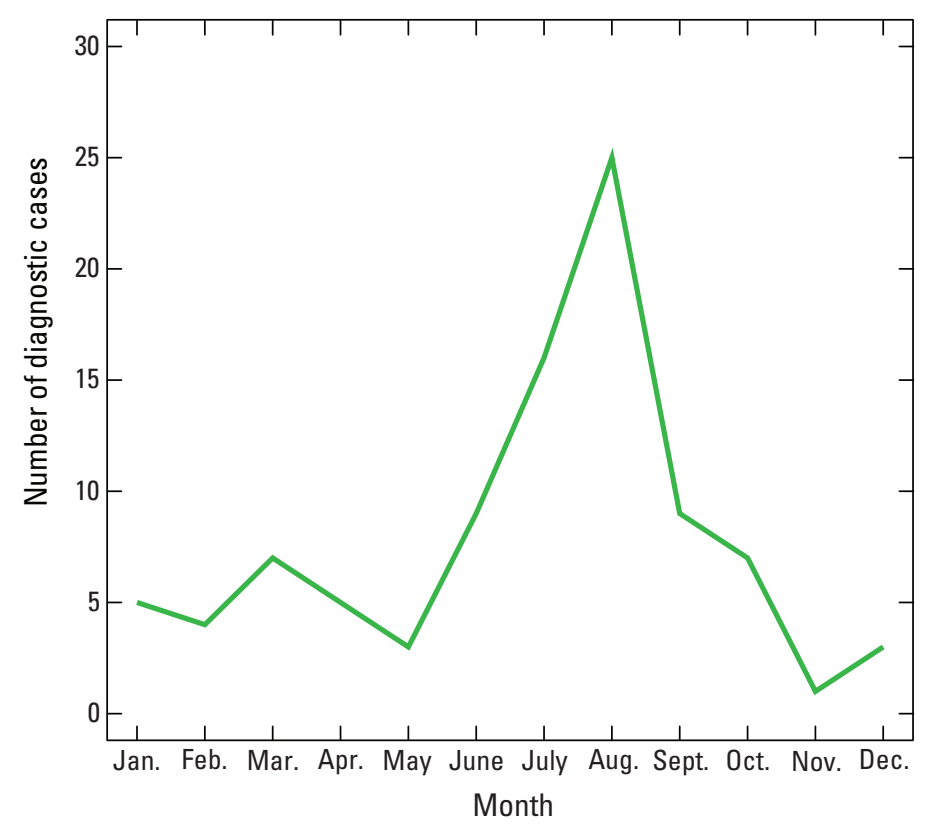

Figure 16. Monthly number of cases of salmonellosis in wild birds.

\section{Significance and Zoonotic Risk}

All serotypes of salmonellae, including the commonly identified S. typhimurium from wild birds, must be considered zoonoses that are potential pathogens to all amphibians, reptiles, birds, and mammals. Because persons may be infected by most serotypes of salmonellae, it is recommended that all persons who handle sick and dead birds around or near their birdfeeders wear disposable gloves or place a plastic bag on their hand when collecting carcasses. Furthermore, handlers of dead birds are urged to practice excellent personal hygiene by thoroughly washing their hands after handling dead birds and bird-feeding stations, and they should remove soiled clothing promptly and wash it. Persons with birdfeeders and dead birds in their yard also are urged to keep their pets away from sick and dead birds, and remove, wash, and disinfect feeding stations weekly. Removing or closing bird-feeding stations is recommended when morbidity and mortality persists after washing and disinfecting the feeder.

\section{Selected References}

Friend, M., 1999, Salmonellosis, chap. 9 of Friend, M., and Franson, J.C., eds., Field manual of wildlife diseases: general field procedures and diseases of birds, U.S. Geological Survey Information and Technology Report 1999-001 p. $99-109$.

Daoust, P., and Prescott, J.F., 2007, Salmonellosis, chap. 13 of Thomas, N.J., Hunter, D.B., and Atkinson, C.T., eds., Infectious diseases of wild birds: Ames, Iowa, Blackwell Publishing, p. 270-288. 


\section{Exotic Trematode Infections}

\section{Cause or Etiology}

In the U.S., three introduced trematodes that were originally native to Europe cause lethal intestinal infections in endemic waterfowl and shorebirds: Cyathocotyle bushiensis, Leyogonimus polyoon, and Sphaeridiotrema globulus. These three exotic trematodes were first detected in 1960s along the St Lawrence River and lower Great Lakes (Gagnon, 1990); in 1996 in Wisconsin; and in 1928 along the Potomac River. Their introduced exotic intermediate host, also from Europe, is the aquatic snail, Bithynia tentaculata. Most native aquatic snails have proven unsuccessful as intermediate hosts for the three introduced trematodes.

\section{Host Species}

Lethal intestinal infections by C. bushiensis, L. polyoon, and $S$. globulus are most commonly detected in lesser scaup ducks and American coots (fig. 17; Fulica americana) (Herrmann and Soreson, 2011). Other waterfowl that may be infected by $C$. bushiensis and $S$. globulus and that usually are found dead with scaups and coots are ruddy ducks (Oxyura jamaicensis), redhead ducks (Aythya ferina), mallards (Anas platyrhynchos), and blue-winged teal (Anas discors). $C$. bushiensis and S. globulus uncommonly are a cause of death in bufflehead ducks (Bucephala albeola), canvasback ducks (Aythya valisineria), ring-necked ducks (Aythya collaris), northern shoveler ducks (Anas clypeata), white-winged scoters

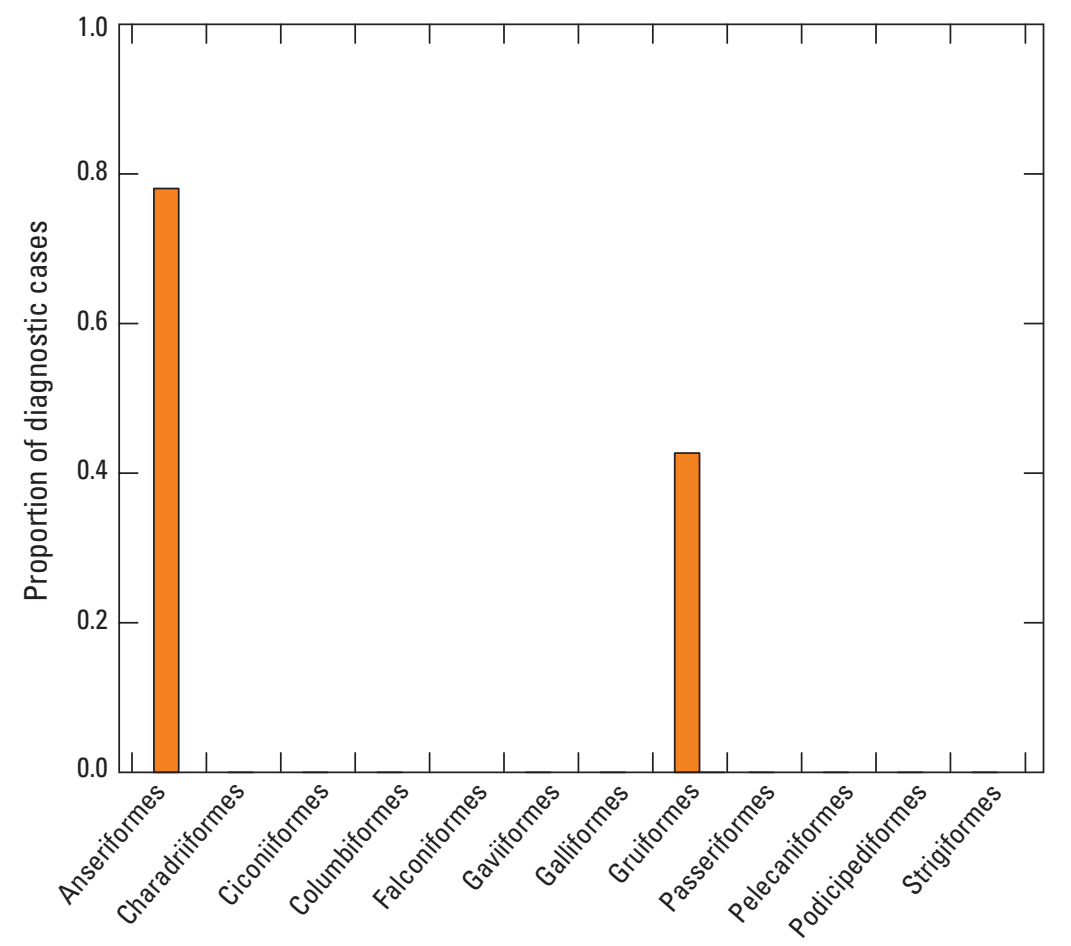

Taxonomic order

Figure 17. Occurrence of exotic trematode infections in wild birds 2001-10, by order.
(Melanitta fusca), Canada geese (Branta canadensis), snow geese (Chen caerulescens), and swans.

The life cycle of the three parasites begins with excretion of parasite eggs by birds in their feces. The trematode eggs hatch and release the motile form of the parasite, the miracidia, into the aquatic environment. Free-swimming miracidia invade aquatic snails, usually Bithynia tentaculata. Life cycles of C. bushiensis, L. polyoon and S. globulus involve one or more intermediate hosts. The first intermediate host for these parasites is an introduced aquatic snail, Bithynia tentaculata, but $S$. globulus also may use other snail hosts including Elimia virginica, Fluminicola virens, and Oxytrema silicula (the latter two snails are native to North America) and pass through multiple stages of development, eventually producing cercariae. Cercariae of C. bushiensis and S. globulus are released by the snail into the water; the free-swimming cercariae then invade and reinfect the individual snail and nearby snails. The cercariae develop into metacercariae in the snail; the metacercariae are the infectious stage when eaten by birds.

The life cycle for L. polyoon is more complicated, with second intermediate hosts that include aquatic insects and amphipods. When Bithynia snails release cercariae of L. polyoon, the free-swimming cercariae may invade numerous intermediate hosts including amphipods and a variety of aquatic insects. The cercariae develop into infectious metacercariae in these invertebrates. In addition, certain predatory aquatic insects, such as caddis fly larvae (order: Tricoptera) and damsel fly larvae (order: Odonata; suborder: Zygoptera) may accumulate live, infectious metacercariae into their bodies by consuming other infected invertebrates. American coots (F. americana) probably become infected by L. polyoon by eating caddis flies and damsel flies. Morbidity and mortality associated with these exotic trematodes is generally limited to wetlands where $B$. tentaculata is present.

\section{Geographic Distribution}

Presently, C. bushiensis, L. polyoon, and S. globulus have a limited distribution in North America (fig. 18). S. globulus has the largest introduced range: it is found along the Potomac River in Maryland; the Hudson River in New York; the St. Lawrence River in Canada and the United States (Gibson and others, 1972); the southern Great Lakes; at least three small inland lakes in Wisconsin (Cole, 2001); the Upper Mississippi River (Sauer and others, 2007), which borders the States of Iowa, Wisconsin and Minnesota; along the Mississippi River in eastern and central Minnesota; and in three or four lakes in western Montana. Infections by C. bushiensis occur in the same regions as $S$. globulus, but they have not been reported on the Potomac and Hudson Rivers. L. polyoon has a limited distribution in Wisconsin and Minnesota, but because the parasite is present 
A. 2001-5

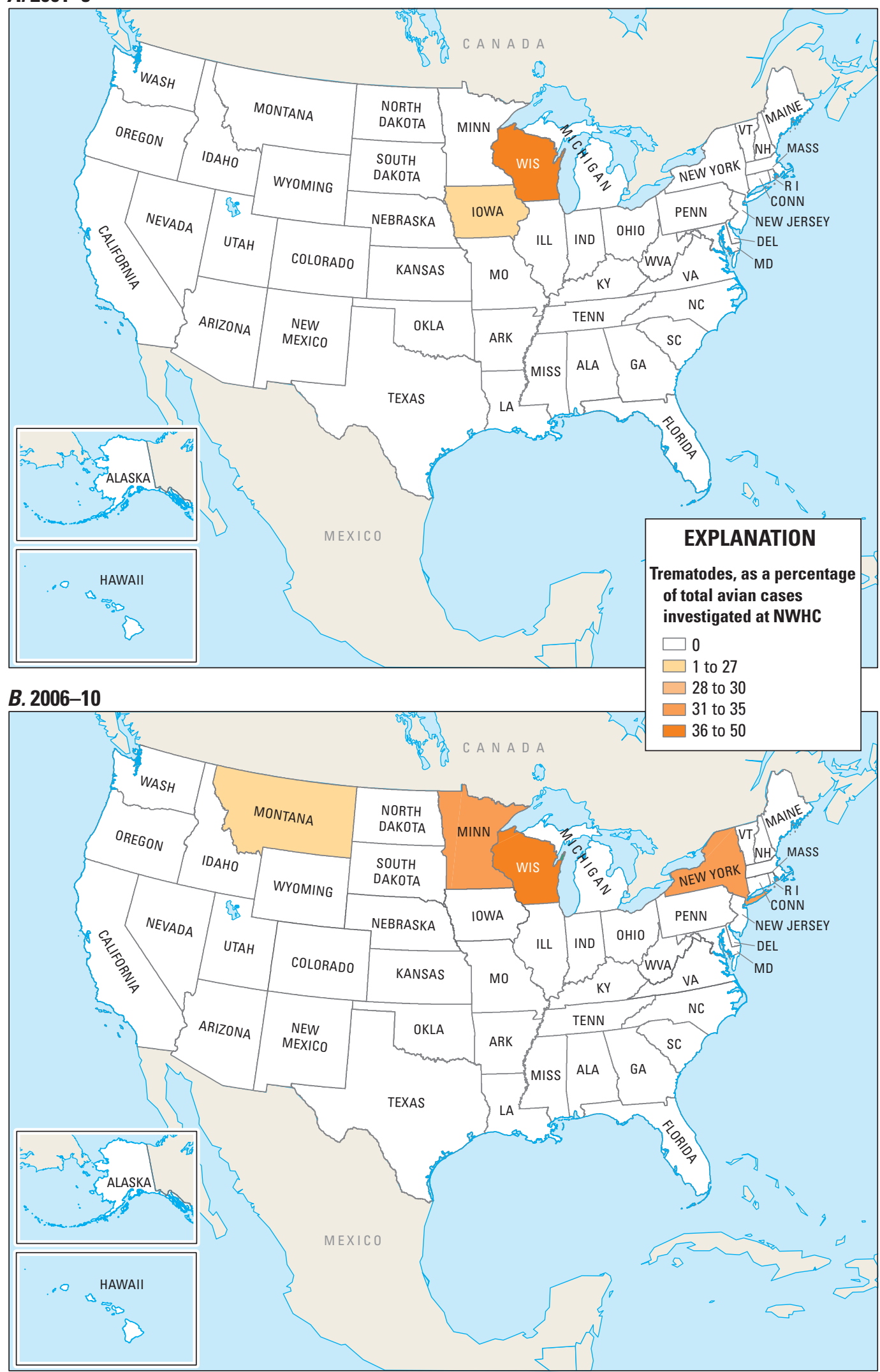

Figure 18. Prevalence of exotic trematode infections diagnosed in wild bird disease outbreaks, as a percentage of all wild bird disease outbreaks, by State, for $A, 2001-5$ and $B, 2006-10$. in the Upper Mississippi River, continued northerly and southerly spread along the river is anticipated. The spread of $C$. bushiensis and $L$. polyoon with infection of waterfowl and shore birds, however, must be preceded by the spread of the exotic host snail, $B$. tentaculata.

\section{Seasonality}

Although these parasites may be found in small mortality events in every month of the year (fig. 20), larger mortality events occur in midspring and mid-autumn and are each associated with northern and southern migrations of waterfowl, respectively. Many of the mortality events in spring and autumn occurred on the upper Mississippi River where waterfowl stop for a few days to rest and feed before resuming their migrations. Mortality rates of up to 11,000 coots at one site in one season have been associated with these trematode parasites in Wisconsin (Cole, 2001).

\section{Signs and Lesions}

Field and clinical signs of infection by exotic trematodes may be confused with botulism, because general weakness and flaccid paralysis are often observed. Some sick birds may show weak flight or dive attempts, a tendency to remain behind and swim into cover when the rest of flock would flush, and may quickly become 
exhausted when trying to escape. Infrequently, a bird may pass bloody or black feces. Affected sick and dead birds usually are in fair to good body condition, consistent with reports of mortality occurring 3-8 days after infection. Internally, C. bushiensis has a tropism for the caeca, but the trematode occasionally is present in the distal ileum and colon. Apices of the caeca may show hemorrhage and diphtheritic or caseous ulcerations in the mucosa. L. polyoon has a tropism for the duodenum and jejunum, where it may cause hemorrhage into the gut lumen. S. globulus has a tropism for the jejunum and ileum, but in heavy infections of more than 3,000 trematodes,

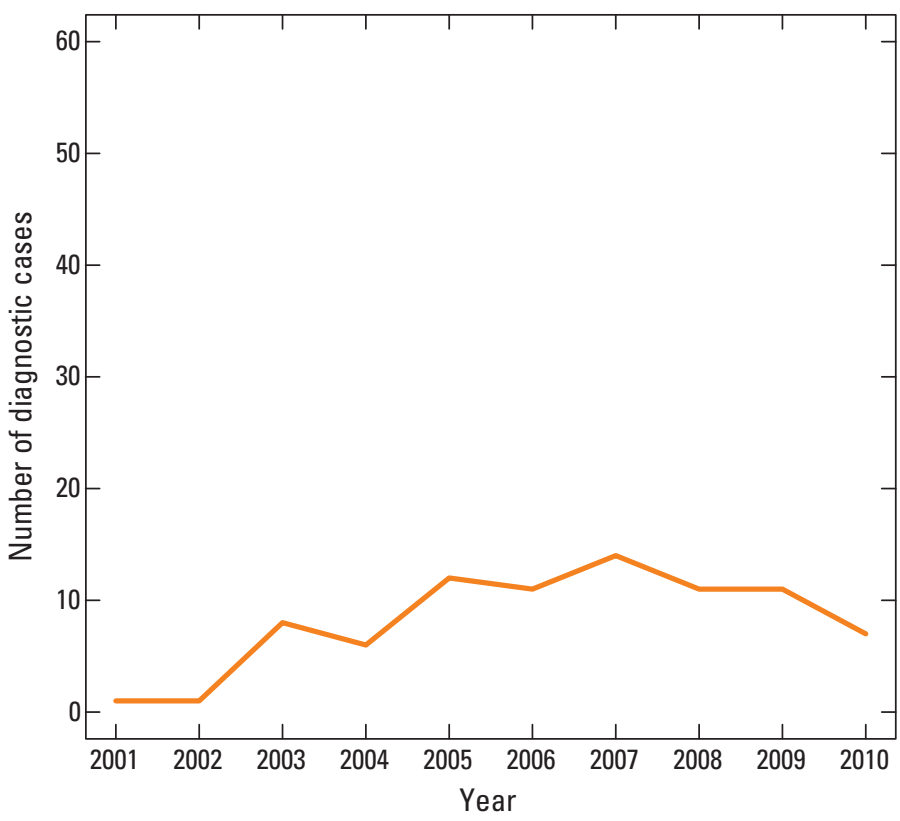

Figure 19. Annual number of cases of exotic trematode infection in wild birds.

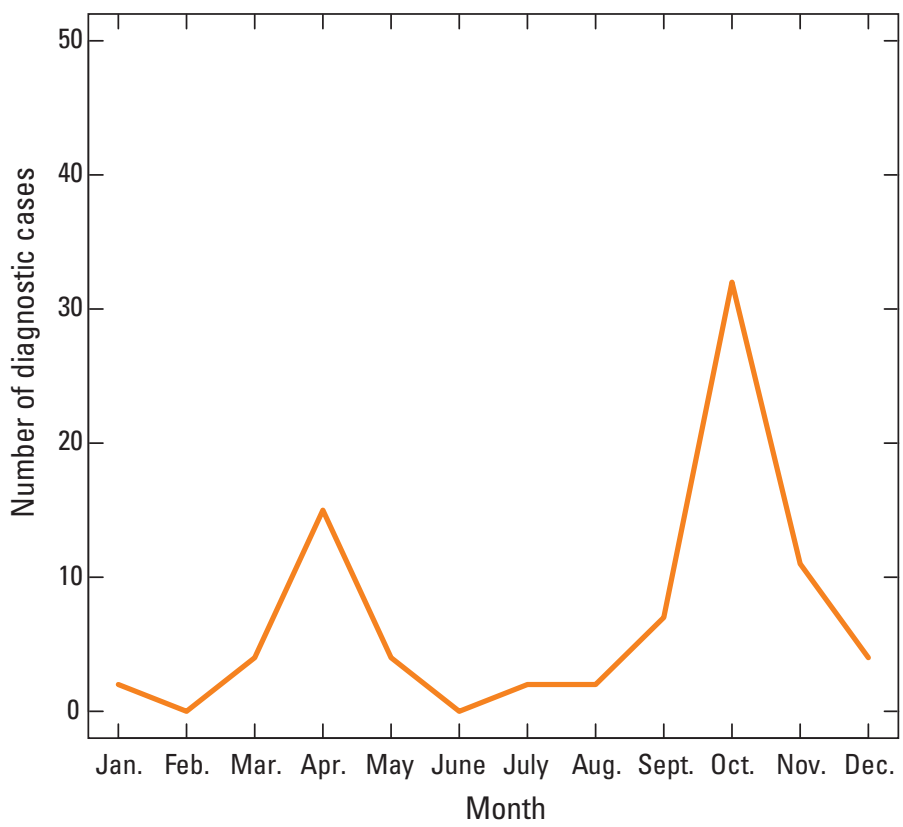

Figure 20. Monthly number of cases of exotic trematode infection in wild birds. the trematodes may also be present in the duodenum and caeca; hemorrhage into the lumen and mild flaccidity and dilation of the wall of the intestine may be present. Fewer than 10 adult $C$. bushiensis have been associated with deaths of waterfowl. C. bushiensis and S. globulus may cause morbidity and mortality as single infections, but it is common for both to be present in the same bird. L. polyoon has a limited geographic distribution restricted to Minnesota and Wisconsin; hence, it usually is found in the presence of the other two species of trematodes.

\section{Significance and Zoonotic Risk}

There is no zoonotic risk to humans and pets by these exotic trematodes, but infections of domestic breeds of ducks and geese are possible. Infections by these trematodes are most common in waterfowl and shorebirds such as scaups and coots, which actively feed on aquatic invertebrates, and are less common in waterfowl such as geese and swans, which generally feed on vegetation.

\section{Selected References}

Cole, R.A., 2001, Exotic parasite causes large scale mortality in American coots: accessed on May 30, 2012, at http:// www.nwhc.usgs.gov/publications/fact_sheets/pdfs/fact_ lpolyoon.pdf.

Cole, R.A., Roderick, C.L., Taft, S., Choudhury, A., Kanev, I., and Brockman-Mederas, K.M., 2000, Life cycle of Leyogonimus polyoon (Trematoda: Lecithodendriidae): presentation at Joint Meetings of the American Society of Parasitologists and Society of Protozoologists, San Juan, Puerto Rico. June 24-28, 2000.

Gagnon, C., 1990, Pathological consequences of infection by Cyathocotyle bushiensis Khan, 1962, and Sphaeridiotrema globulus (Rudolphi, 1814) in two species of dabbling ducks: Montreal, Quebec, Canada, McGill University, M.S. thesis, $167 \mathrm{p}$.

Gibson, G.G., Broughton, E., and Choquette, L.P.E., 1972, Waterfowl mortality caused by Cyathocotyle bushiensis Khan, 1962 (Trematoda: Cyathocotylidae), St. Lawrence River, Quebec: Canadian Journal of Zoology, v. 50, no. 11, p. 1351-1356.

Herrmann, K.K., and Sorenson, R.E., 2011, Differences in natural infections of two mortality-related trematodes in lesser scaup and American coot: Journal of Parasitology v. 97 , no. 4 , p. $555-558$.

Sauer, J.S., Cole, R.A., and Nissen, J.M., 2007, Finding the exotic faucet snail (Bithynia tentaculata): investigation of waterbird die-offs in the Upper Mississippi River National Wildlife and Fish Refuge: U.S. Geological Survey OpenFile Report 2007-1063, 3 p. 


\section{Lead Poisoning (Plumbism)}

\section{Cause or Etiology}

Lead poisoning is a persistent disease that is declining due to a ban on the use of lead shot in hunting waterfowl in 1991. Lead shot pellets are persistent in the environment, however, so ingestion of lead remains a problem in numerous areas where waterfowl were hunted throughout most of the $20^{\text {th }}$ century. Lead poisoning also is associated with accidental ingestion of lead fishing sinkers by fish-eating birds (Franson and others, 2003) and ingestion by eagles and other avian scavengers of lead bullet fragments in the discarded entrails of hunter-killed deer and other big game animals. Infrequent cases of lead poisoning are associated with ingestion of chips and flakes of lead-based paint from old buildings and ingestion of mine wastes or other lead-based objects. In the U.S., some States have implemented local or regional bans on lead bullets and lead fishing tackle, but legislation to ban lead bullets and fishing tackle nationwide has not been passed. The use of lead shot is inconsistently banned for hunting upland gamebirds, including doves, so lead poisoning following ingestion of lead shot in terrestrial birds remains a problem (Franson and others, 2009).

\section{Host Species and Annual Distribution}

Lead poisoning affects a wide range of bird species, but in the years of this report, more than 95 percent of cases involved waterfowl (ducks, geese, and swans) and eagles (95 percent bald eagles; 5 percent golden eagles) (fig. 21). Other lead poisoned birds included three common loons, two sandhill cranes (Grus canadensis), a cowbird, and a black vulture (Coragyps atratus). The number of lead poisoning cases declined by 38 percent between 2001-5 (170 cases) and 2006-10 (96 cases). The data may be skewed towards submission of eagles, (81 percent of all cases between 2001 and 2005 and 69 percent of all cases between 2006 and 2010 were eagles).

\section{Geographic Distribution}

Lead poisoning is a nationwide problem (fig. 22), and only seven States (Hawai'i, Nevada, Alabama, Georgia,

Delaware, Massachusetts, and Rhode Island) had no confirmed cases in 2001-10; however, lead poisoning had been detected in birds in several of the seven States in the prior years. The number of birds submitted from some of the seven States also was limited.

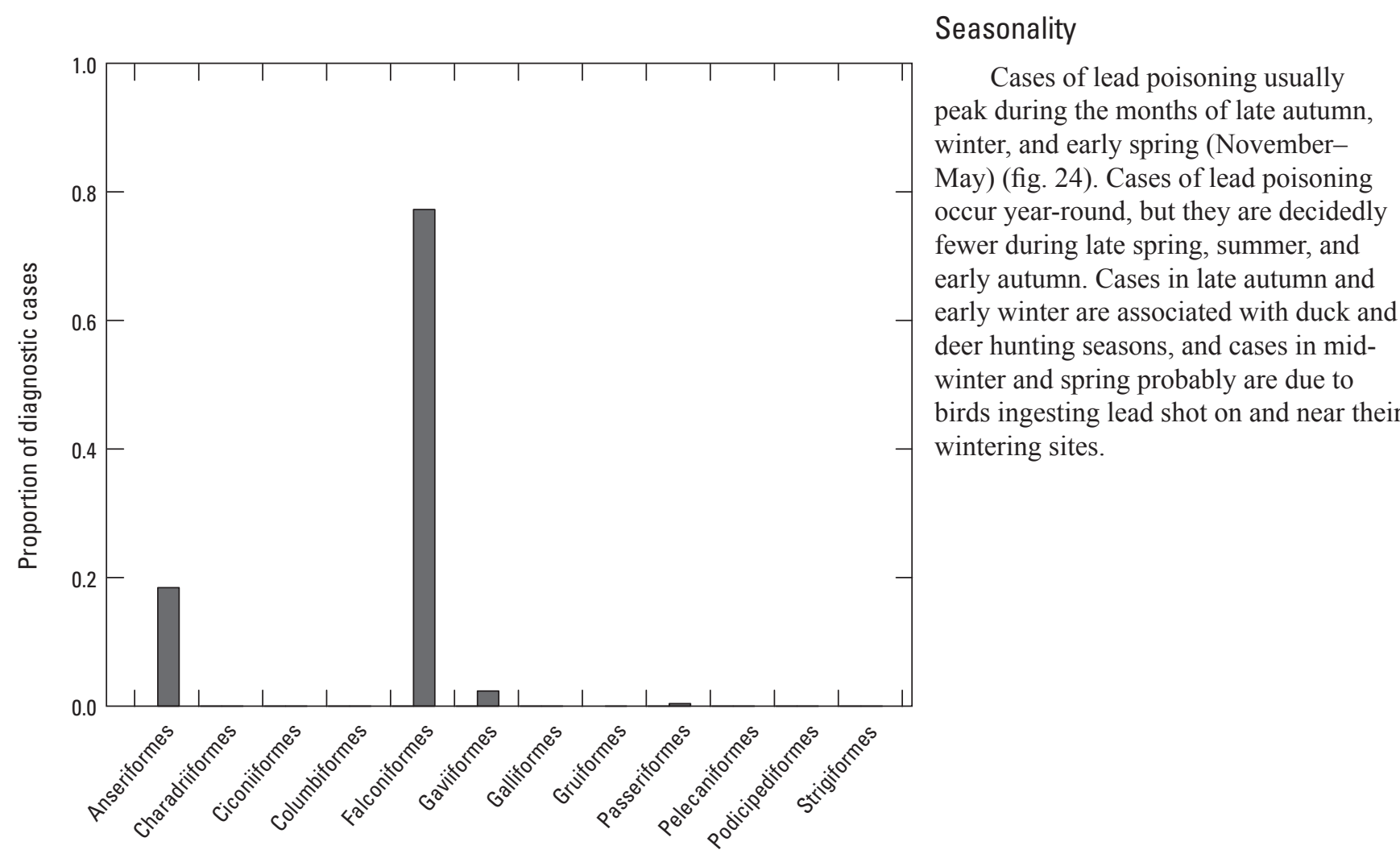

Taxonomic order

Figure 21. Occurrence of lead poisoning in wild birds 2001-10, by order. 


\section{A. 2001-5}

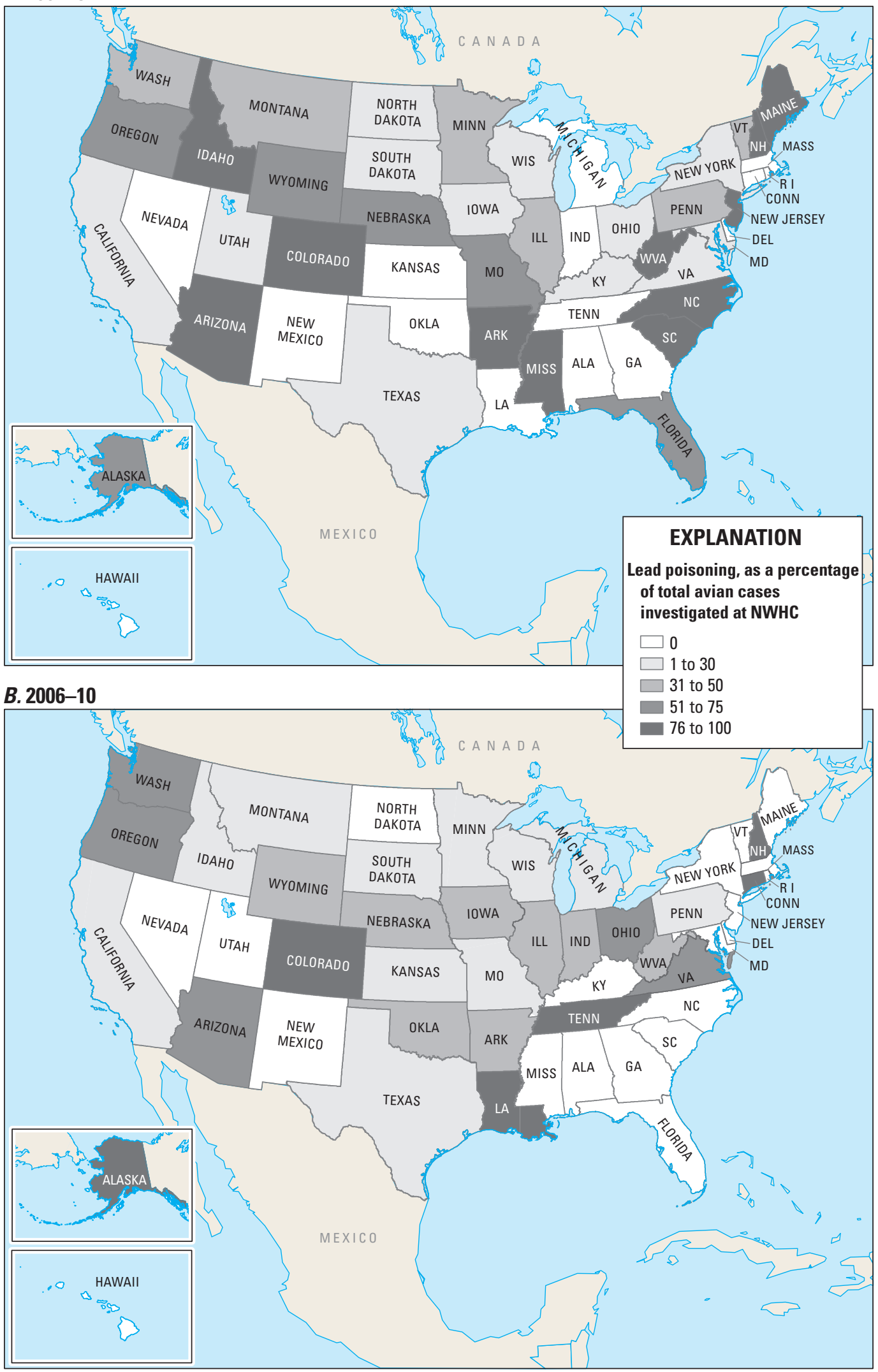

Figure 22. Prevalence of lead poisoning diagnosed in wild birds, as a percentage of all wild bird disease outbreaks, by State, for $A, 2001-5$ and $B, 2006-10$. 


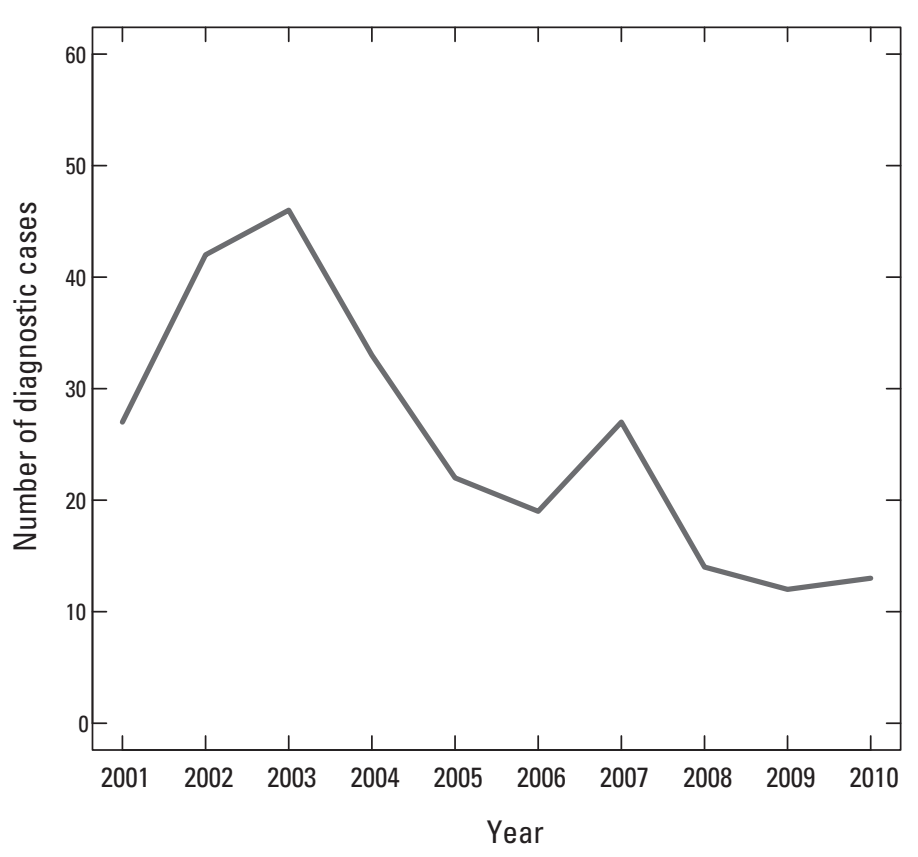

Figure 23. Annual number of cases of lead poisoning in wild birds.

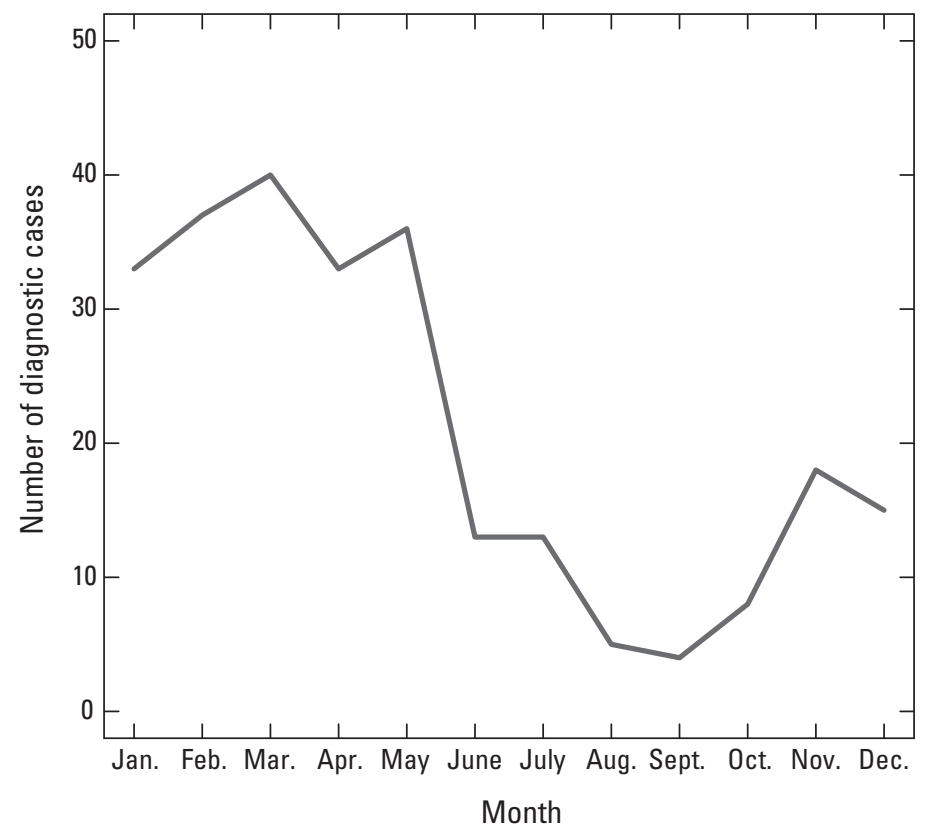

Figure 24. Monthly number of cases of lead poisoning in wild birds.

\section{Signs and Lesions}

Most birds with lead poisoning have a chronic intoxication and are moderately to severely emaciated. Uncommon cases of lead poisoning in well-nourished birds are considered to be examples of acute lead poisoning. In the field, poisoned birds are weak, ataxic, fearless, and may be reluctant to fly or fly weakly. Affected Canada geese may have abnormal crooked postures of the head and neck during flight, and a marked change in tone of the call is occasionally evident. Waterfowl also may show abnormal postures or paralysis of the wings. At necropsy, lead poisoned birds usually have no body fat and severe atrophy of breast (pectoral) muscles. Distention or impaction of the esophagus and proventriculus with feed is noted in less than 25 percent of poisoned waterfowl. Offending lead objects may be detected in the lumen of the gizzard.

\section{Significance and Zoonotic Risk}

Risk of secondary lead poisoning in predators, scavengers, pets, and humans is highly variable. The amount of lead in tissues, for example, the muscles and liver, of lead poisoned waterfowl is considered insufficient for a person to develop clinical signs of poisoning by eating one or a few birds. Consumption of a large number of poisoned birds in a few days would be necessary for toxic levels to accumulate in humans; however, consumption of lead shot in the flesh of waterfowl may lead to clinical lead poisoning in children and adults. Predators and scavengers may become secondarily poisoned by ingesting lead shot and bullet fragments in the gizzards, flesh, or entrails of animals.

\section{Selected References}

Franson, J.C., Hansen, S.P., Creekmore, T.E., Brand, C.J., Evers, D.C., Duerr, A.E., and DeStefano, S., 2003, Lead fishing weights and other fishing tackle in selected waterbirds: Waterbirds, v. 26, p. 345-352.

Franson, J.C., Hansen, S.P.,; and Schulz, J.H., 2009, Ingested shot and tissues lead concentrations in mourning doves, in, Watson, R.T.; Fuller, M.; Pokras, M.; and Hunt, W.G., eds., Ingestion of lead from spent ammunition: implications for wildlife and humans: Boise, Idaho, The Peregrine Fund, p. 1-12.

Pain, D.J., Cromie, R.L., Newth, J., Brown, M.J., Crutcher, E., Hardman, P., Hurst, L., Mateo, R., Meharg, A.A., Moran, A.C., Raab, A., Taggart, M.A., and Green, R.E., 2010, Potential hazard to human health from exposure to fragments of lead bullets and shot in the tissues of game animals: PLOS ONE, v. 5, no. 4, p. 1-17, accessed November 29, 2012, at http://www.plosone.org/article/ info:doi\%2F10.1371\%2Fjournal.pone.0010315

The Wildlife Society and American Fisheries Society, 2008, Sources and implication of lead ammunition and fishing tackle on natural resources: Technical Review 08-01, 62 p. 


\section{Virulent Newcastle Disease Virus}

\section{Cause or Etiology}

Virulent Newcastle disease virus (vNDV) belongs in the genus, Rubulavirus, in the viral family, Paramyxoviridae, and Subfamily, Paramyxovirinae. Several strains of NDV have been identified, but only some strains are designated "virulent." Isolates of vNDV are considered virulent only when poultry (chickens) are affected and may or may not be virulent to wild birds. Virulent and nonvirulent isolates of NDV are considered one species of virus: avian paramyxovirus-1 (APMV-1). This virus has a ribonucleic acid (RNA) genome and other viruses in the genus, Rubulavirus, include human mumps virus, avian paramyxovirus-2 through 9 , human parainfluenza virus- 2 and 4 , three simian and porcine viruses, and probably Hendra virus of fruit bats, horses, and humans in Australia. Isolates of vNDV and NDV in recent years have been named cormorant paramyxovirus, pigeon paramyxovirus, and others. Each isolate of NDV, regardless of host species of bird, only is designated virulent (vNDV) when its virulence in chickens is established or a specific virulence gene is detected molecularly.

\section{Host Species and Annual Distribution}

Between 2001 and 2010, vNDV has been isolated almost exclusively from double-crested cormorants (Phalacrocorax auritus) in the U.S. (fig. 25). The vast majority of these isolates come from die-offs of nestling and fledgling cormorants from colonial nesting sites. Usually, these colonial nesting sites also have nesting pelicans, gulls, and other shorebirds, but vNDV has not been isolated from other species of birds at cormorant nesting sites.

\section{Geographic Distribution}

Virulent Newcastle disease virus has been detected in die-offs of immature cormorants in seven States including South Dakota, Minnesota, Wisconsin, California, Maryland, Nevada, and North Dakota; however, over half of the cases of vNDV in cormorants have occurred in States bordering the Great Lakes (Wisconsin and Minnesota; fig. 26). Colonies of nesting cormorants also are common in North and South Dakota, where vNDV has been detected four times since 2001. Isolates of APMV-1 from cormorants prior to 2001 were poorly characterized, so it is unknown when vNDV may have emerged as a disease in cormorants.

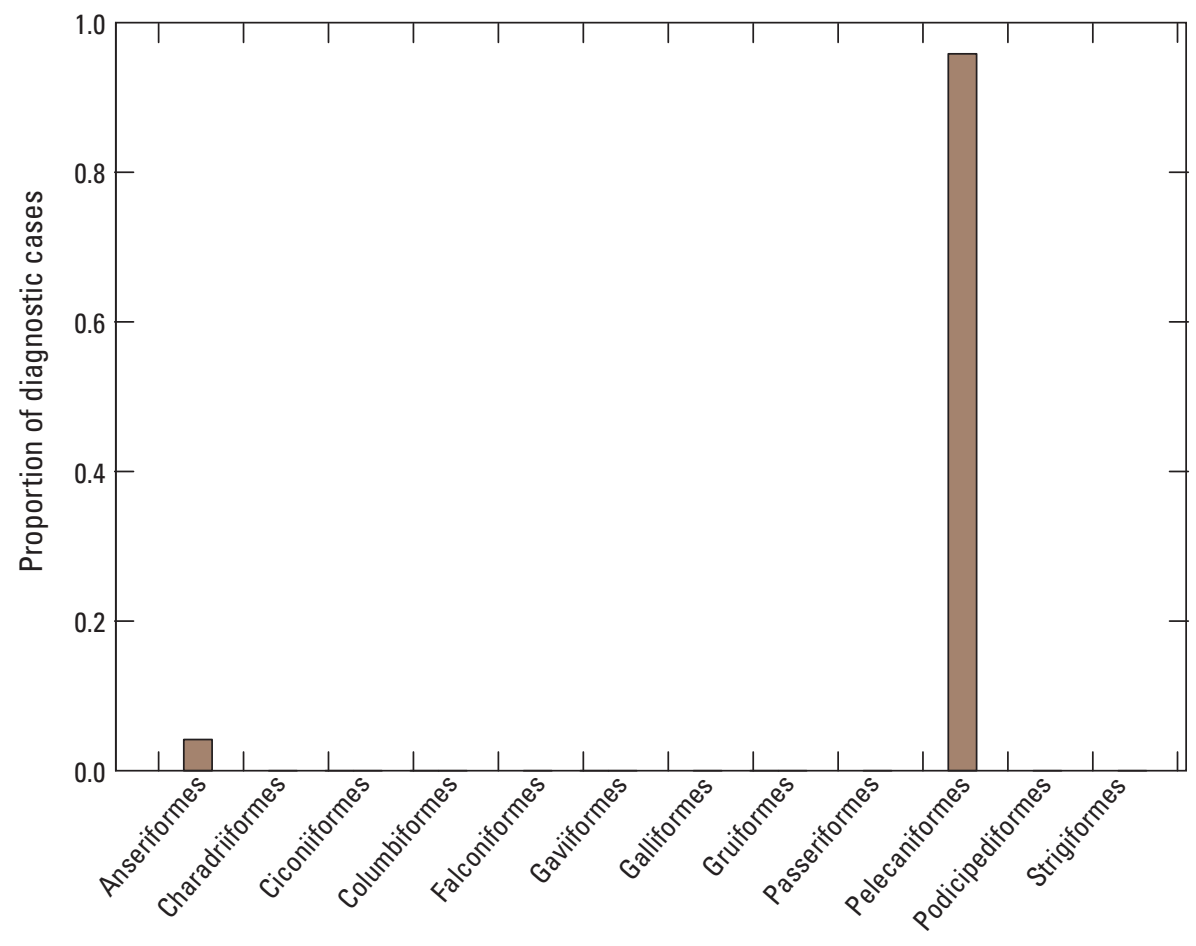

Taxonomic order

Figure 25. Occurrence of virulent Newcastle disease virus in wild birds 2001-10, by order. 


\section{A. 2001-5}

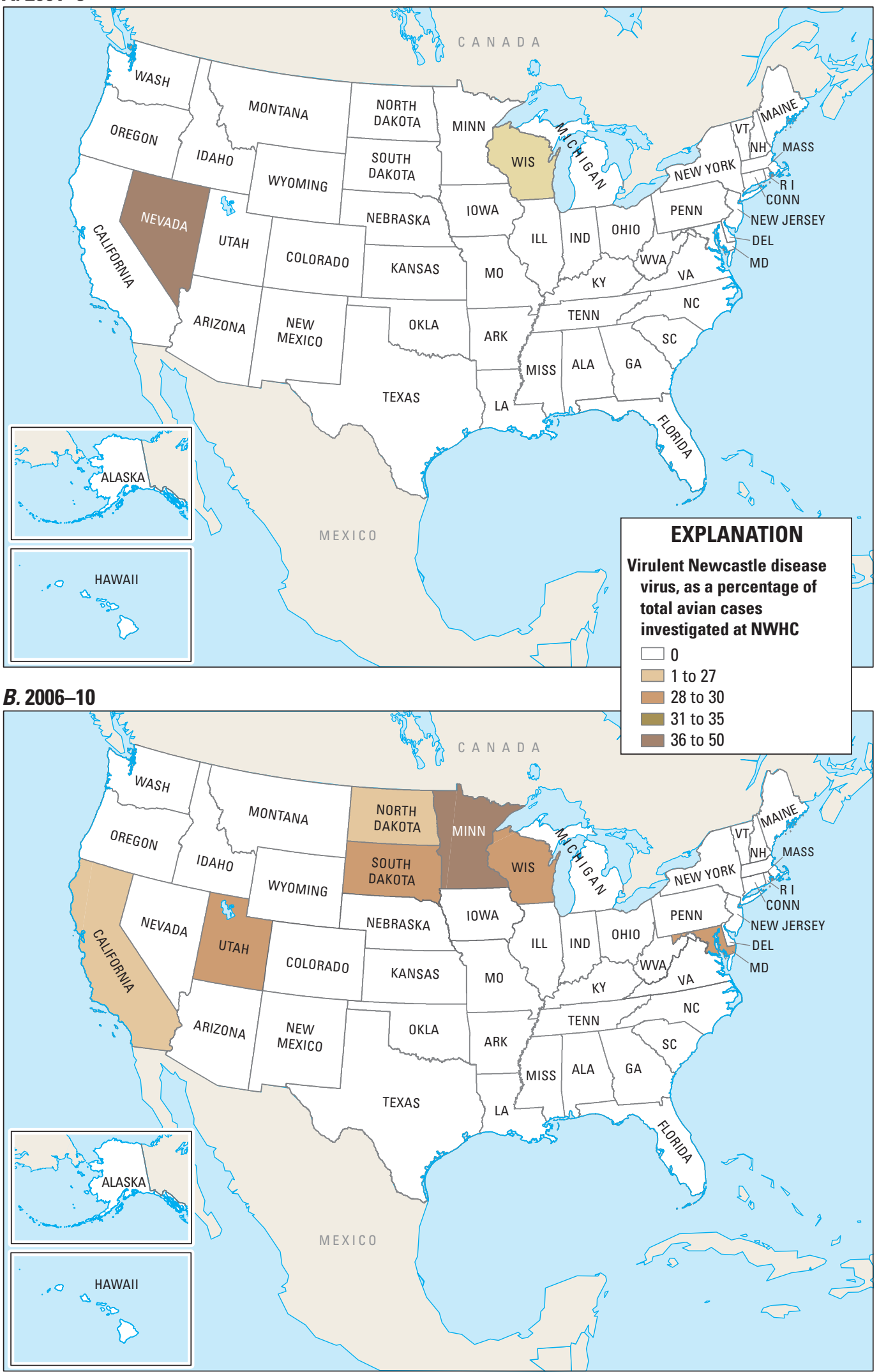

\section{Seasonality}

Because vNDV occurs predominantly in nestling and fledgling double-crested cormorants, there is a strong seasonal occurrence of the disease in months of the late spring and early summer. There is some variability in months of first occurrence that generally is related to weather conditions. About 75 percent of cases of vNDV are reported in June, July, August, September, and October (fig. 28).

\section{Signs and Lesions}

Nestling cormorants usually are found dead in or near their nests with no record of clinical signs. Fledgling cormorants also may be found dead, but also are detected because of neurological signs including severe lethargy, ataxia, or paralysis of one or more limbs. Infected nestlings may be emaciated or in fair to good body condition, while fledgling cormorants with neurological signs are more likely to be emaciated. No specific abnormalities are detected grossly in visceral organs of vNDV-infected cormorants, but histologically, many fledgling cormorants have minimal to moderate nonsuppurative encephalitis.

Figure 26 Prevalence of virulent Newcastle disease virus diagnosed in wild bird disease outbreaks, as a percentage of all wild bird disease outbreaks, by State, for $A, 2001-5$ and $B, 2006-10$. 


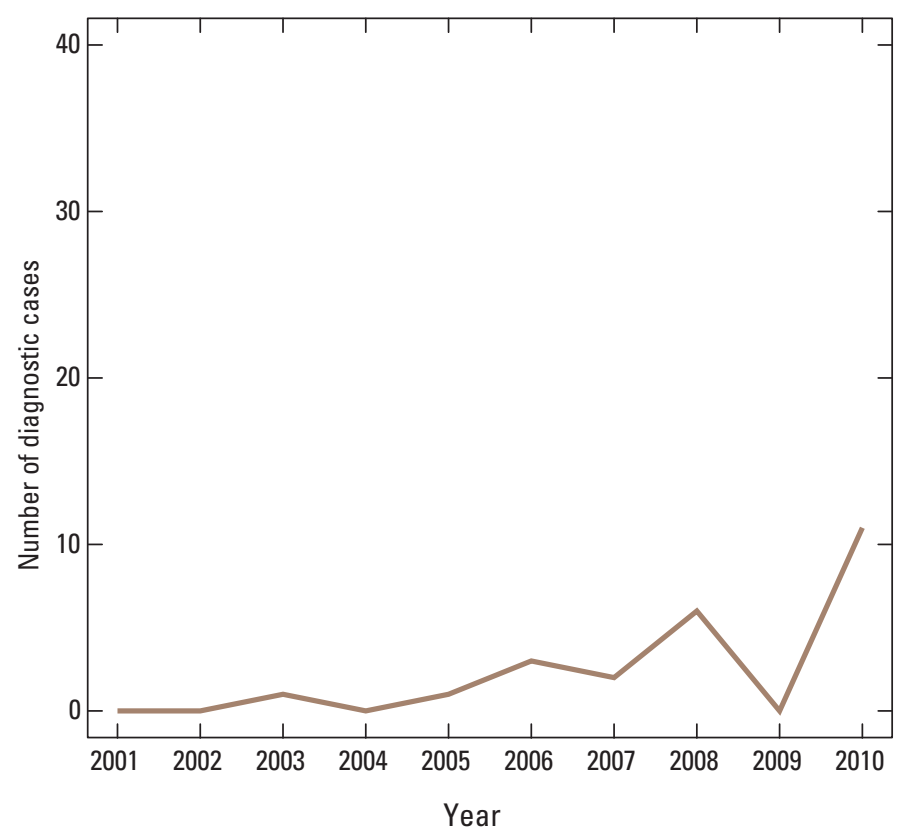

Figure 27. Annual number of cases of virulent Newcastle disease virus in wild birds.

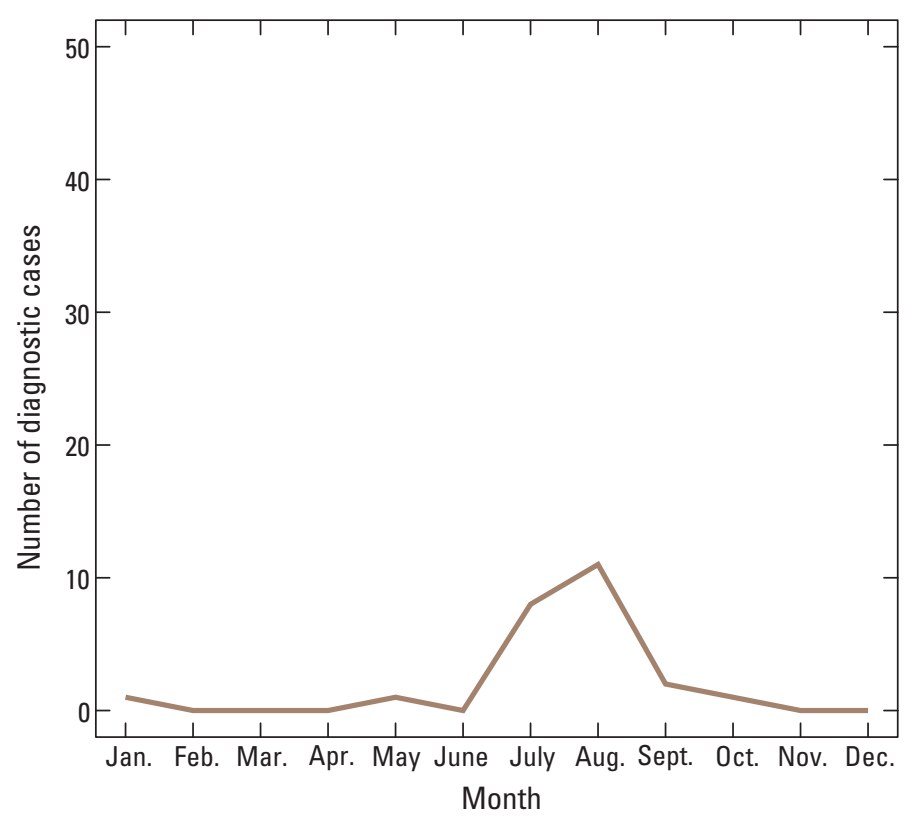

Figure 28. Monthly number of cases of virulent Newcastle disease virus in wild birds.

\section{Significance and Zoonotic Risk}

Although there are rare reports of humans developing mild infections by NDV, human infections by vNDV from cormorants have not been documented. Although vNDV has only been detected in cormorants in the U.S. in the last 10 years (2001-10), it is likely other wild birds are susceptible to infection and we remain alert for this occurrence.

\section{Selected References}

Cattoli, G., Susta, L., Terregino, C., and Brown, C.; 2111, Newcastle disease: a review of field recognition and current methods of laboratory detection: Journal of Veterinary Diagnostic Investigation, v. 23, no. 4, p. 637-656.

Diel, D.G., Miller, P.J., Wolf, P.C., Mickley, R.M., Musante, A.R., Emanueli, D.C., Shively, K.J., Pedersen, K., and Afonso, C.L., 2012, Characterization of Newcastle disease viruses isolated from cormorant and gull species in the United States in 2010: Avian Diseases, v. 56, p. 128-133.

Hines, N.L., Killian, M.L., Pedersen, J.C., Reising, M.M., Mosos, N.A., Mathieu-Benson, C., and Miller, C.L., 2012, An rRT-PCR assay to detect the matrix gene of a broad range of avian paramyxovirus serotype-1 strains: Avian Diseases, v. 56, p. 387-395. 


\section{West Nile Virus}

\section{Cause or Etiology}

West Nile virus (WNV) is in the genus, Flavivirus, in the family, Flaviviridae, which are all mosquito-borne viruses with RNA as their genome. Other viruses in the genus, Flavivirus, include Dengue virus, Japanese encephalitis virus, yellow fever virus, and several other tick-borne and mosquitoborne species of virus. The viral genomes that were examined from infected birds and humans in the U.S. suggest the strain of WNV introduced into the New York City area in 1999 may have originated from Israel (Lanciotti and others, 1999).

\section{Host Species and Annual Distribution}

West Nile virus has been isolated in cultures from many species of dead birds and a few squirrels. To date, WNV has not been isolated from any species of amphibians, nor any turtles and tortoises (chelonians). Mammals larger than squirrels are infrequently submitted to the NWHC, so we have not isolated WNV from native wild cats (felids), foxes and wolves (canids), raccoons (procyonids), and groundhogs, beavers, pikas, rabbits, and field mice (rodents and lagomorphs). The bird most commonly infected by WNV was the American white pelican (fig. 29; 75 of 172 cases, or 44 percent). Infected pelicans were mostly nestlings and fledglings in colonial nesting sites from northern States; adults were infrequently infected. Other species of birds at the same nesting sites, including gulls, terns, and cormorants, also were infected but at much lower frequency. Raptors including owls, vultures, falcons, hawks, and eagles were the second most commonly infected group of birds (34 of 172, or 19.8 percent); most infected raptors were adult or subadult birds. Most raptors also were emaciated, while pelicans and other shorebirds such as terns and gulls usually were in fair to good body condition, indicating the latter group of birds probably had acute systemic infections similar to those in crows, jays, and other corvids. It must be noted that these data include only cases submitted as part of mortality investigations; cases submitted as part of the WNV surveillance system, which largely consisted of corvids, are not included in this summary.

The specific mosquitoes involved in the transmission of WNV to wild birds were not studied when sick and dead birds were collected.

\section{Geographic Distribution}

West Nile virus was first detected in dead American crows and zoological birds in New York City in 1999. Within months, the virus spread northwards and southwards to adjacent States. Within 5 years, the virus had spread westward to most of the contiguous 48 States (fig. 30). The spread of WNV into new States and counties often was marked by deaths of urban and suburban American crows (Caffrey and others, 2005; Eidson and others, 2001), although, WNV has been isolated from many species of passerines, pelicans, raptors, waterfowl, shorebirds, and others. WNV is now considered endemic in the lower 48 States but has not been detected in Alaska or Hawaii.

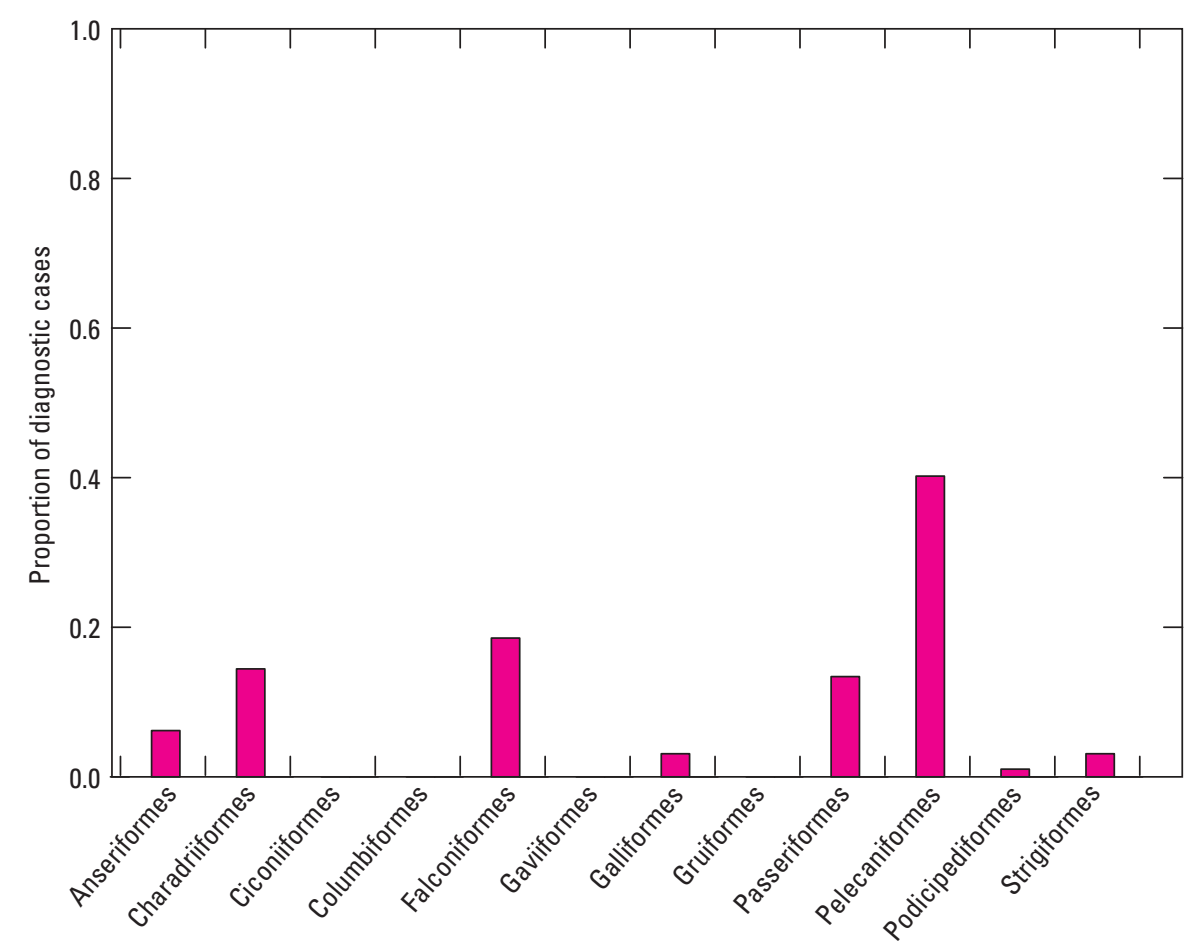

Taxonomic order

\section{Seasonality}

Occurrence of infection by WNV is strongly linked to time of the year (fig. 32). Morbidity and mortality associated with WNV generally occurs annually a few weeks following emergence of large populations of mosquitoes. The first fatal cases of infection by WNV generally occur in July or August, but cases may appear months earlier in southern States. Generally, cases of WNV decline abruptly and sharply following the first freezing weather in the autumn. Detection of infections by WNV in winter months is rare.

Figure 29. Occurrence of West Nile virus in wild birds 2001-10, by order. 


\section{A. 2001-5}

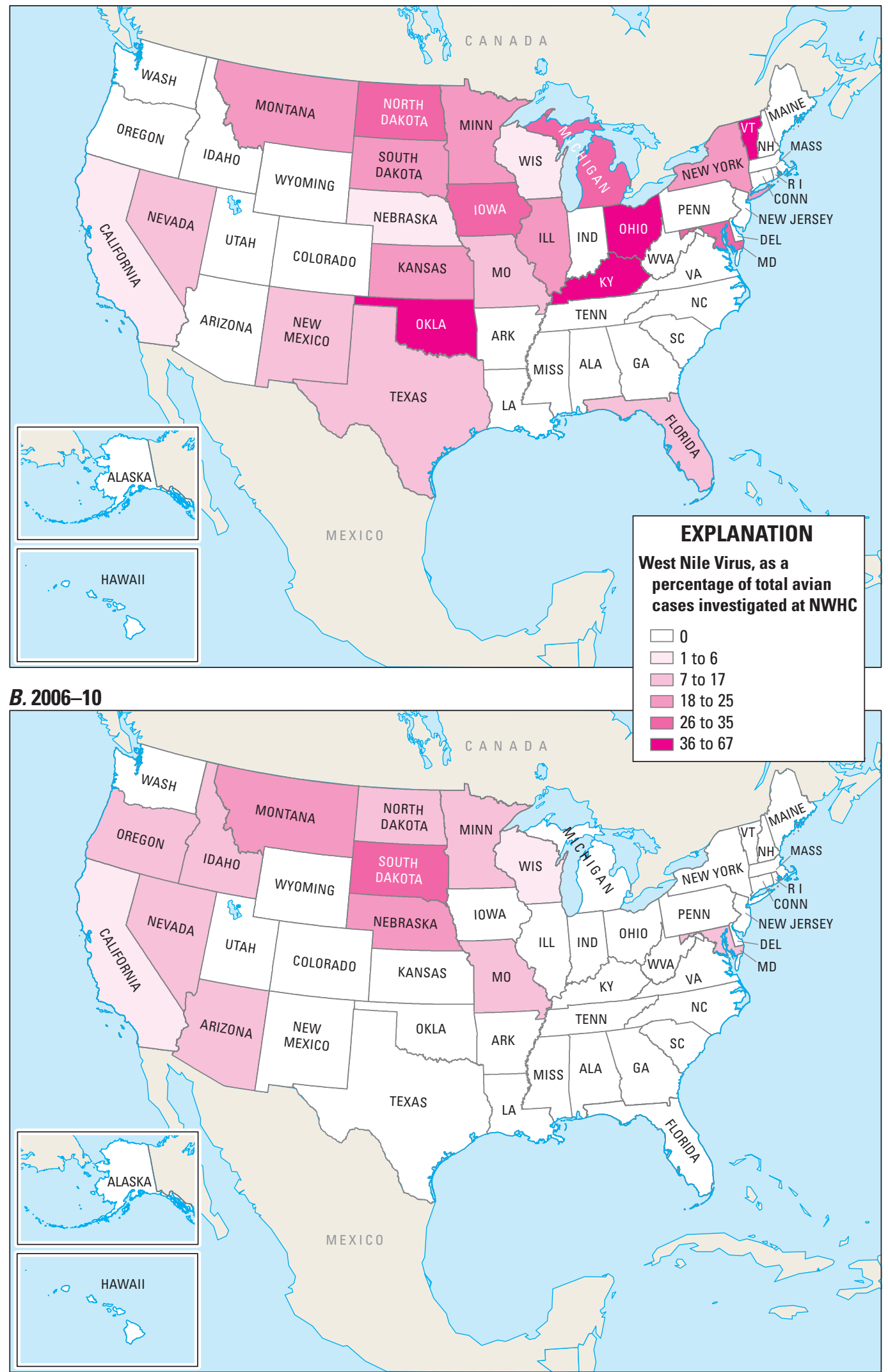

Signs and Lesions

Passerine birds, including corvids, generally are found dead and signs prior to death are seldom observed. Immature pelicans, gulls, terns, and cormorants with infections by WNV are usually found dead, but a small number are found collapsed, semicomatose, or very lethargic. Raptors with infection by WNV usually are adults or subadults. Neurological signs predominate in infected raptors, including head tilt, limb paralysis, ataxia, and inability to fly or walk. Most raptors also are emaciated and have nonsuppurative encephalitis, while most passerines are in fair to good body condition.

\section{Significance and Zoonotic risk}

Direct transmission of WNV from birdto-bird or bird-tomammal is rare and generally involves laboratory accidents, failure of laboratory staff to use personal protective equipment, or infrequently, bird or mammal scavenging or consumption of WNVinfected carcasses.
Figure 30. Prevalence of West Nile virus in wild bird disease outbreaks, as a percentage of all wild bird disease outbreaks, by State, for $A, 2001-5$ and $B, 2006-10$. 


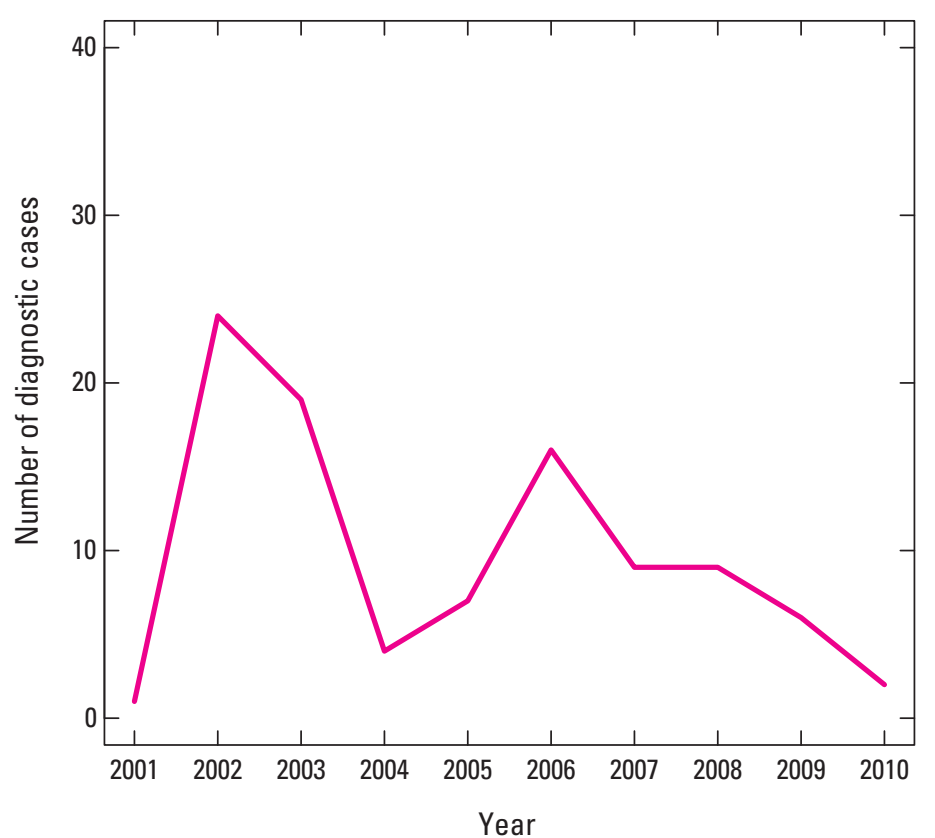

Figure 31. Annual number of cases of West Nile virus in wild birds.

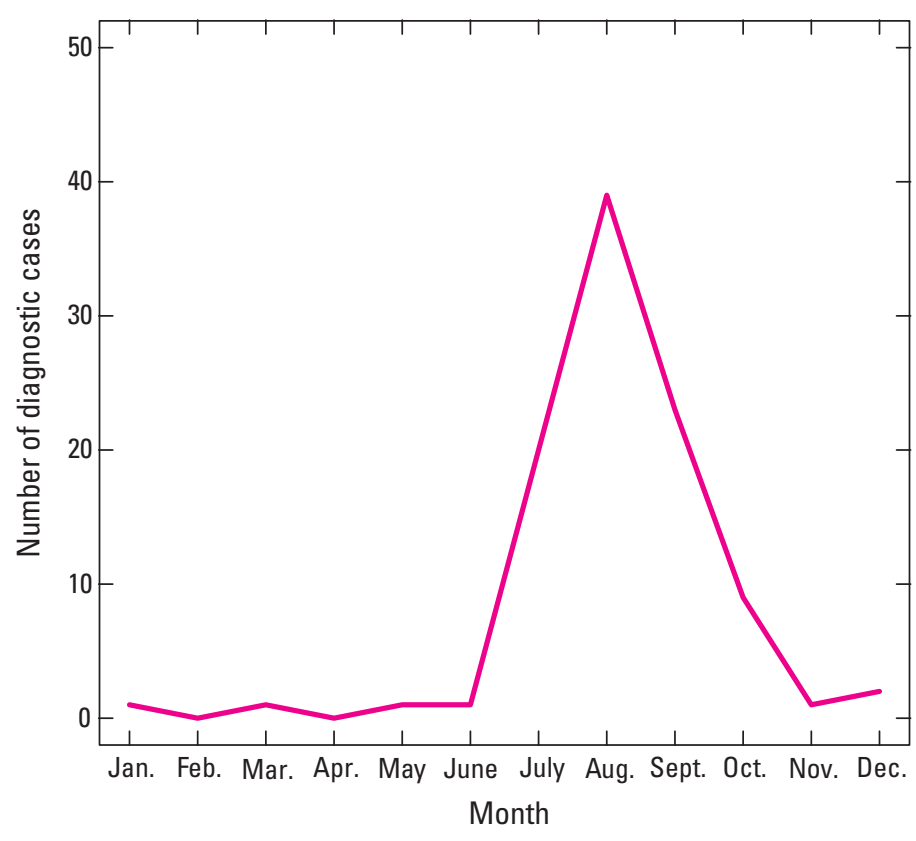

Figure 32. Monthly number of cases of West Nile virus in wild birds.
Although WNV is considered a zoonotic disease, the major hazard to persons probably is from exposure to infected mosquitoes while doing field work. Although pet dogs and cats can be exposed to WNV if they consume infected carcasses, most cases of WNV infection in pets probably are owing to transmission by bites of mosquitoes. Many States and counties begin soliciting the collection and submission of dead passerine birds from urban and suburban locations in the spring and then publicize the first detection of WNV in a dead bird each year to alert citizens of the need to apply insect repellants to avoid infection while outdoors.

\section{Selected References}

Caffrey, C., Smith, S.R.C., and Weston, T.J., 2005, West Nile virus devastates an American crow population: The Condor, v. 107, p. $128-132$.

Dusek, R.J.; McLean, R.G.; Kramer, L.D.; Ubico, S.R.; Dupuis, A.P., II; Ebel, G.D.; and Guptill, S.C., 2009, Prevalence of West Nile virus in migratory birds during spring and fall migration: American Journal of Tropical Medicine and Hygiene, v. 81, no. 6, p. 1151-1158.

Eidson, M., Kramer, L., Stone, W., Hagiwara, Y., Schmitt, K., and the New York State West Nile Virus Avian Surveillance Team, 2001, Dead bird surveillance as an early warning system for West Nile virus: Emerging Infectious Diseases, v. 7, p. 615-620.

Hofmeister, E.K., 2011, West Nile virus: North American experience: Integrative Zoology, v. 6, p. 279-289.

Lanciotti, R.S., Roehrig, J.T., Deubel, V., Smith, J., Parker, M., Steele, K., Volpe, K.E., Crabtree, M.B., Scherret, J., Hall, R., Mackenzie, J., Cropp, C.B., Panigraphy, B., Malkinson, M., Komar, N., Savage, H.M., Stone, W., McNamara, T., and Gubler, D.J., 1999, Origin of the West Nile virus responsible for an outbreak of encephalitis in the northeastern United States: Science, v. 286, p. 2333-2337.

McLean, R.G., and Ubico, S.R., 2007, Arboviruses in birds, chap. 2 of Thomas, N.J.; Hunter, D.B.; and Atkinson, C.T., eds., Infectious diseases of wild birds: Ames, Iowa, Blackwell Publishing, p. 17-62.

Weingartl, H.M., Neufeld, J.L., Copps, J., and Marszal, P., 2004, Experimental West Nile virus infection in blue jays (Cyanocitta cristata) and crows (Corvus brachyrhynchos): Veterinary Pathology, v. 41, p. 362-370.

Wunschmann, A., Shivers, J., Carroll, L., and Bender, J., 2004, Pathological and immunohistochemical findings in Americans crows (Corvus brachyrhynchos) naturally infected with West Nile virus: Journal of Veterinary Diagnostic Investigation, v. 16, p. 329-333. 


\section{Selected Herpetological Diseases}

\section{Amphibian Chytridiomycosis}

\section{Cause or Etiology}

The pathogenic chytrid fungus of amphibians is Batrachochytrium dendrobatidis ("Bd"). There probably is no other single disease agent in human records that has caused more global deaths, decimations, extirpations, and extinctions than Bd has caused to the order Anura, which includes frogs and toads (Skerratt and others, 2007). Chytrid fungi are a distinct phylum of protists called Chytridiomycota, and Bd is the only species of chytrid fungus to parasitize or infect vertebrate animals. Numerous taxa of chytrid fungi are ubiquitous in the environment, especially wetlands. Although other genera of chytrid fungi break down keratin proteins found in skin, hair, feathers, and claws or insect exoskeletons (chitin) in the environment, Bd of amphibians is an infection strictly of keratinized epidermal cells, and thus chytridiomycosis has not been detected in fish, reptiles, birds, or mammals. Chytrid fungi cause intracellular infections and form spherical to ovoid thalli (microscopic single-cell structures); chytrid fungi do not form hyphae like higher fungi. The infectious stage of $\mathrm{Bd}$ is a uniflagellate zoospore that forms in, and is released from, the thalli. Resting stages or environmentally hardy spores have not been described, but it is not clear how the organism seems to persist in wetlands year after year without suitable amphibian hosts or through drying of wetlands.

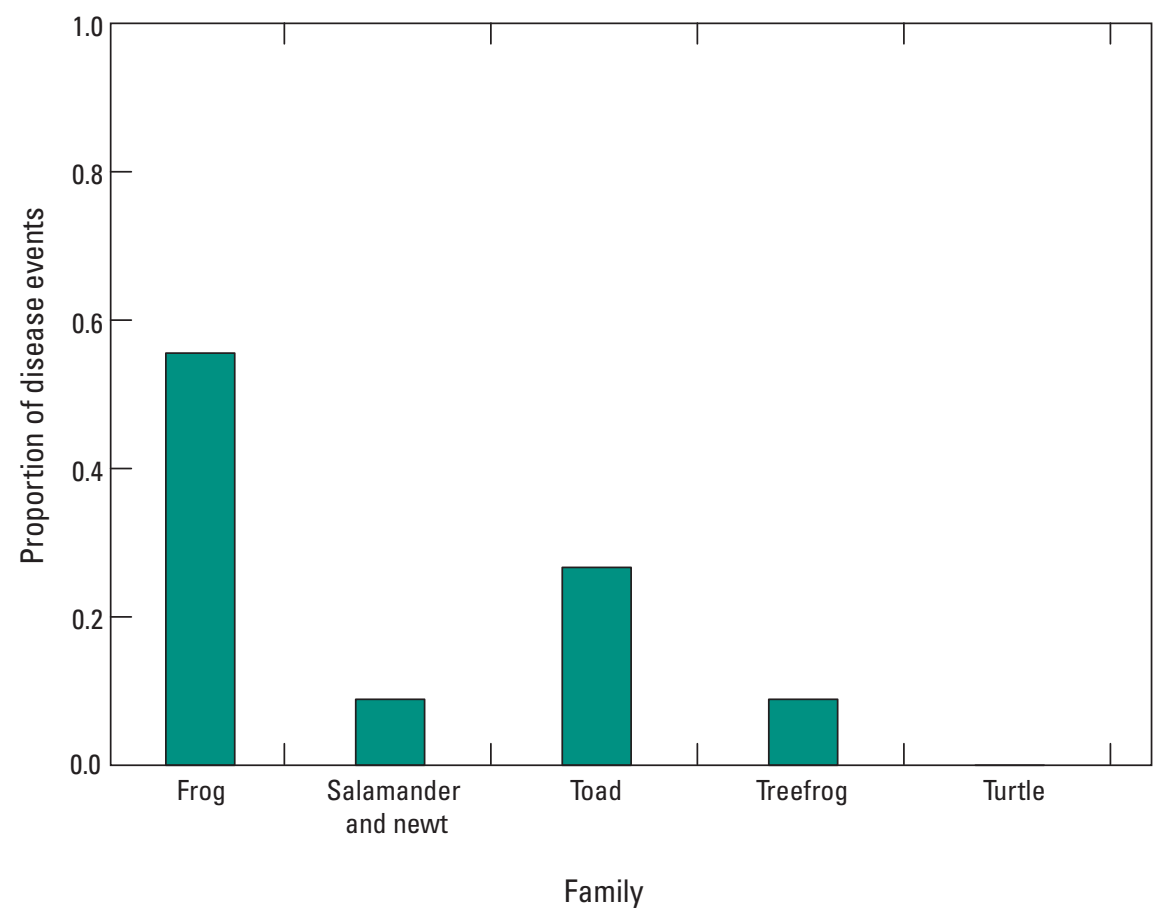

Figure 33. Occurrence of chytridiomycosis in amphibians, by family.

\section{Host Species}

Chytridiomycosis is an infection of amphibian larvae and postmetamorphs, but it is lethal only in postmetamorphic frogs and toads (fig. 33). During metamorphosis, the epidermis of amphibians changes from keratin-free larval skin to keratinized adult skin. The only keratin in larval frogs and toads occurs in the oral disc; the black jaw sheaths and tooth rows are the only keratin in tadpoles. Larval salamanders may have traces of keratin at the tips of their digits, but lethal infections of larval amphibians are not reported, probably because of their very limited amount of keratin. It is likely that where chytridiomycosis occurs in the larvae, very few amphibians can complete metamorphosis quickly enough to escape chytrid infection of their newly forming keratinized adult skin. Bd infections are rarely lethal in adult salamanders with the exception of eastern red-spotted newts (Notophthalmus viridescens) and most genera of salamanders in Central and South America. Susceptibility of caecilians (legless amphibians) is largely unknown.

\section{Geographic Distribution}

Batrachochytrium dendrobatidis is found on all six continents that have endemic amphibians and also on many large and small island nations. Based on histological studies of museum specimens in the northern and western United States and western Canada, this infection first appeared in the late 1960s and early 1970s. It was the probable cause of massive amphibian population declines in the 1970s and then extirpation of populations and extinctions of many species in subsequent decades. $\mathrm{Bd}$ was not identified, however, until the mid to late 1990s (Berger and others, 1998), which may have allowed its international dissemination. The geographic origin of $\mathrm{Bd}$ is unknown, although there is some evidence that the pathogen is endemic to southern Africa (Weldon and others, 2004) and may have been spread globally by the importation of millions of live wild-borne African clawed frogs (Xenopus laevis) for research and clinical studies.

In semitropical, tropical, and neotropical locations, chytridiomycosis tends to be distributed by elevation. Amphibian species and populations above $200-400$ meters tend to be much more susceptible to chytridiomycosis than species found at lower elevations, probably because of cooler temperatures at higher elevations. Because $\mathrm{Bd}$ is psychrophilic and ceases to grow at temperatures above $30-32{ }^{\circ} \mathrm{C}$, the infection may be inhibited at hotter, lower elevations in tropical regions (Woodhams and others, 2003); however, Bd also is killed by freezing. 


\section{A. 2001-5}

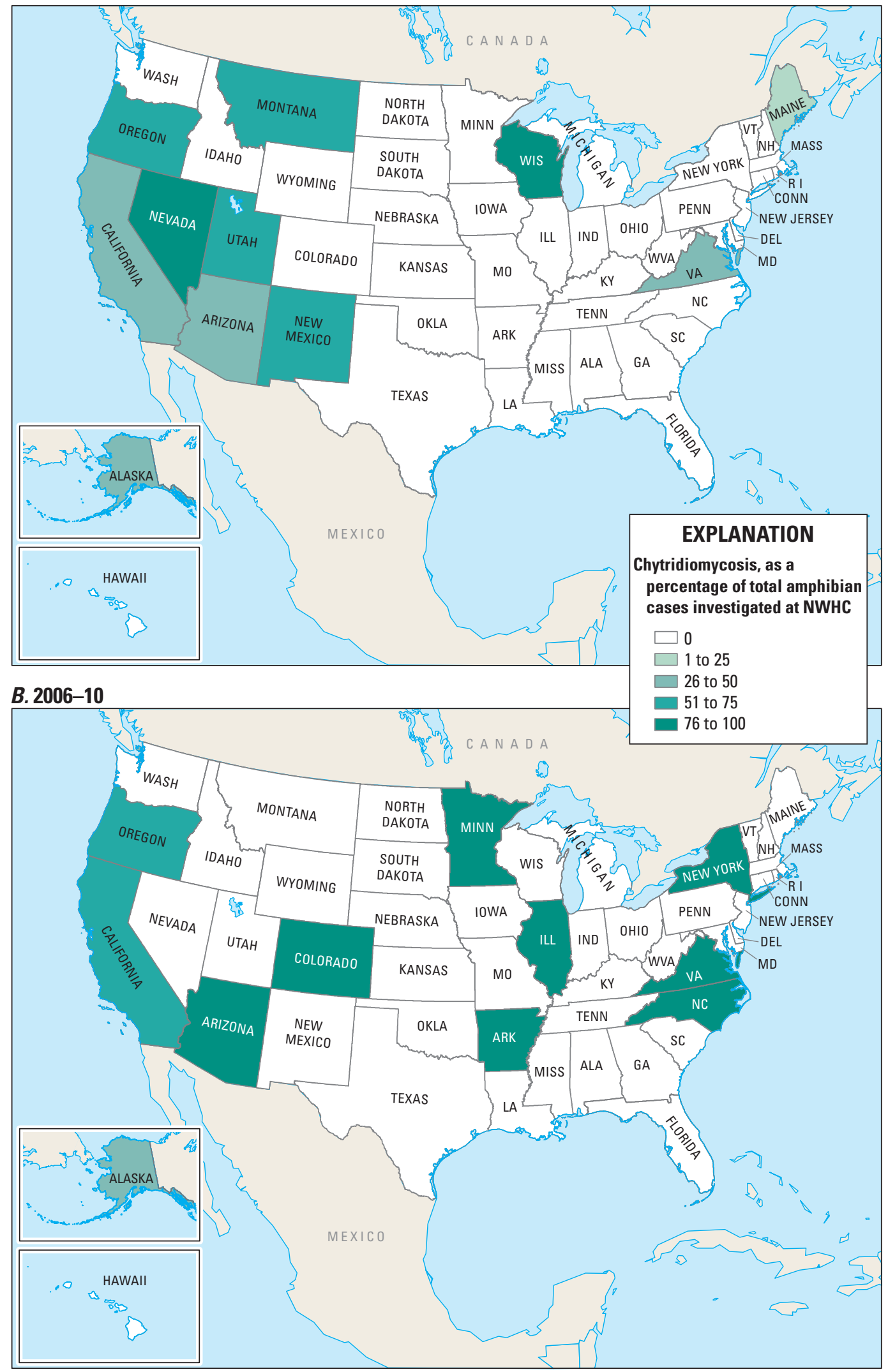

Figure 34. Prevalence of chytridiomycosis diagnosed in amphibians, as a percentage of all amphibian disease outbreaks, by State, for $A, 2001-5$ and $B, 2006-10$.

\section{Seasonality}

Chytridiomycoses (lethal and nonlethal infections) have been detected in amphibians in every month (fig. 36), but lethal infections of postmetamorphs tend to occur during cool weather rather than cold or hot weather. Hence, in southwestern States, where summers usually are hot (greater than $30^{\circ} \mathrm{C}$ ), sick and dead amphibians usually are detected in the late autumn, winter, and early spring. In temperate regions, the infection may be seen throughout the late spring, summer, and autumn. At higher elevations, where snowmelt may not be complete until late spring, chytridiomycosis is mostly detected during summer months. In temperate zones and high altitudes, mortality events may occur promptly following the completion of metamorphosis in May, June, and July. Some tadpoles may persist as larvae for one or two winters, and infections in tadpoles may be detected year-roundeven in those collected beneath ice-covered lakes.

\section{Signs and Lesions}

Mortality events due to chytridiomycosis usually are insidious and often pass undetected. The paucity of observed casualties is greatly disproportionate to the severity of the population decline. In tadpoles (the anuran larval stage), the infection is limited to specific structures of the oral disc and palate. Normally, 
the jaw sheaths and tooth rows of tadpoles are black; with chytrid infection, there is a loss of the black keratinized cells, and these structures show varying degrees of white discoloration. Mortalities associated with oral chytridiomycosis in tadpoles do not occur. In postmetamorphic frogs and toads, chytrid infections may begin promptly in newly formed keratinized adult skin. Mortality rates in recently metamorphosed frogs and toads may be exceedingly high. Infected postmetamorphs are lethargic, fearless, and may have a poor righting reflex. The infection is most intense in the ventral skin, digits, and toe webs, and is absent or minimal in the dorsal skin. Some infected frogs and toads may show abnormal molt (dysecdysis) in which flakes of unshed skin remain attached to the body or the tips of digits. In advanced infections, the ventral skin may appear mildly thickened and light grayish-brown. Because amphibians do not drink water but absorb it through their skin, it is suspected that accumulation of numerous layers

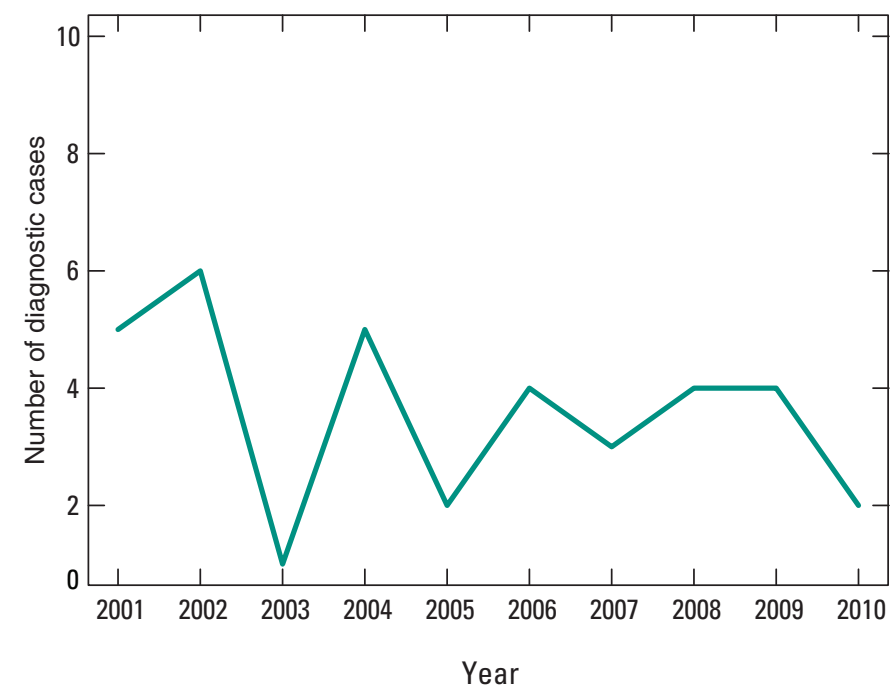

Figure 35. Monthly number of cases of chytridiomycosis in amphibians.

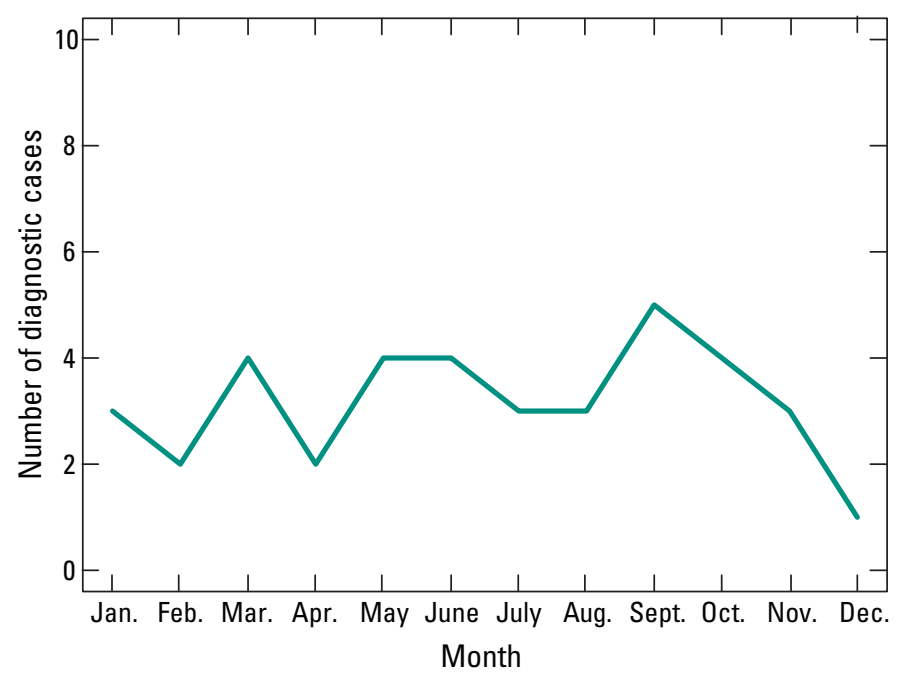

Figure 36. Monthly number of cases of chytridiomycosis in amphibians. of unshed skin may inhibit water absorption; consequently, amphibians with severe infections often are found along shorelines or in surface water. Cause of death in chytridiomycosis is attributed to disruption of cutaneous functions resulting in lethal fluctuations in plasma electrolytes and subsequent cardiac arrest (Voyles and others, 2010).

\section{Significance and Zoonotic Risk}

Infection by $\mathrm{Bd}$ is a global epizootic, but the infection is limited to amphibians. There are no reports of Bd infection in any other class of vertebrates such as fish, reptiles, endotherms, or humans.

\section{Selected References}

Berger, L., Speare, R., Daszak, P., Green, D.E., Cunningham, A.A., Goggin, C.L., Slocombe, R., Ragan, M.A., Hyatt, A.D., McDonald, K.R., Hines, H.B., Lips, K.R., Marantelli, G., and Parkes, H., 1998, Chytridiomycosis causes amphibian mortality associated with population declines in the rainforests of Australia and Central America: Proceedings of the National Academy of Sciences of the United States of America, v. 95, no. 15, p. 9031-9036.

Berger, L., Speare, R., Hines, H.B., Marantelli, G., Hyatt, A.D., McDonald, K.R., Skerratt, L.F., Olsen, V., Clarke, J.M., Gillespie, G., Mahony, M., Sheppard, N., Williams, C., and Tyler, M.J., 2004, Effect of season and temperature on mortality in amphibians due to chytridiomycosis: Australian Veterinary Journal, v. 82, no. 31-36.

Hyatt, A.D., Boyle, D.G., Olsen, V., Boyle, D.B., Berger, L., Obendorf, D., Dalton, A., Kriger, K., Hero, M., Hines, H., Phillott, R., Campbell, R., Marantelli, G., Gleason, F., and Colling, A., 2007, Diagnostic assays and sampling protocols for the detection of Batrachochytrium dendrobatidis: Diseases of Aquatic Organisms, v. 73, p. 175-192.

Skerratt, L.F., Berger, L., Speare, R., Cashins, S., McDonald, K.R., Phillott, A.D., Hines, H.B., and Kenyon, N., 2007, Spread of chytrdiomycosia has cause the rapid global decline and extinction of frogs: EcoHealth, v. 4, p. 125-134.

Voyles, J., Young, S., Berger, L., Campbell, C., Voyles, W.F., Dinudom, A., Cook, D., Webb, R., Alford, R.A., Skerratt, L.F., and Speare, R., 2010, Pathogenesis of chytridiomycosis, a cause of catastrophic amphibian declines: Science, v. 326 , p. 582-585.

Weldon, C., du Preez, L.H., Hyatt, A.D., Muller, R., and Speare, R., 2004, Origin of the amphibian chytrid fungus: Emerging Infectious Diseases, v. 10, p. 2100-2105.

Woodhams, D.C., Alford, R.A., and Marantelli, G., 2003, Emerging disease of amphibians cured by elevated body temperature: Diseases of Aquatic Organisms, v. 55, p. $65-67$. 


\section{Ranavirus}

\section{Cause or Etiology}

Ranaviruses are deoxyribonucleic acid (DNA)-based viruses of the genus, Ranavirus, in the family, Iridoviridae. Occasionally, amphibian ranaviruses are called iridoviruses, but because there is a genus of insect viruses called Iridovirus, this practice is to be avoided. The type species of amphibian ranavirus is frog virus-3 (FV-3) which was first isolated and identified in the 1960s. Multiple strains of amphibian ranaviruses have been reported; most noteworthy are FV-3 and Ambystoma tigrinum (tiger salamander) ranavirus. Other strains or isolates of ranaviruses often are named, for example, Bohle virus in Australia, Redwood Creek virus in northern California, and Southern High Plains virus, but the status of most isolates as species of Ranavirus has yet to be clarified. Ranaviruses also cause morbidity and mortality in fish and reptiles. Other viruses in the family, Iridoviridae, mostly infect insects and fish.

\section{Host Species}

Mortality events due to ranaviruses occur most commonly in aquatic larval amphibians such as mole salamanders (Ambystoma spp.), true frogs (Rana spp.), and chorus frogs (Pseudacris spp.) (fig. 37). Infrequent isolates have been obtained from adult newts (Notophthalmus viridescens), adult treefrogs (Hyla spp.), and postmetamorphic Columbia spotted frogs (Lithobates [formerly Rana] luteiventris). At this laboratory, ranaviruses have been isolated from 16 species of frogs, 1 species of toad, and 6 species of salamanders. In States east of the Mississippi River, especially the Atlantic coastal States, mortality events tend to involve all species within the affected wetland, for example, frogs, toads, and salamanders; in the Western States, where amphibian species are less diverse, mortality events tend to involve only one species per event.

\section{Geographic Distribution}

Amphibian ranaviruses probably are present in every State with the possible exception of Hawai'i. In the 10 years of this report, mortality events attributed to ranaviruses were diagnosed in 25 States (fig. 38). Ranaviruses were detected in amphibians in some States, for example, Oklahoma, Louisiana, Georgia, New Jersey and Connecticut, where ranaviruses often were found in association with other infectious diseases.

\section{Seasonality}

Because mortality events due to ranaviruses mostly affect larval amphibians, there is a strong correlation between ranaviral die-offs and the presence of amphibian larvae in the spring and summer. Mortality events often are first detected in wetlands in April (fig. 40) when large populations of wood frogs (Lithobates sylvaticus, formerly Rana sylvatica) are present in eastern and northern wetlands. Early- and midsummer die-offs due to ranaviruses tend to involve a variety of amphibian species nationwide. Late summer and autumn mortality events involve mostly larval American bullfrogs (Lithobates catesbeianus, formerly Rana catesbeiana) and tiger salamanders.

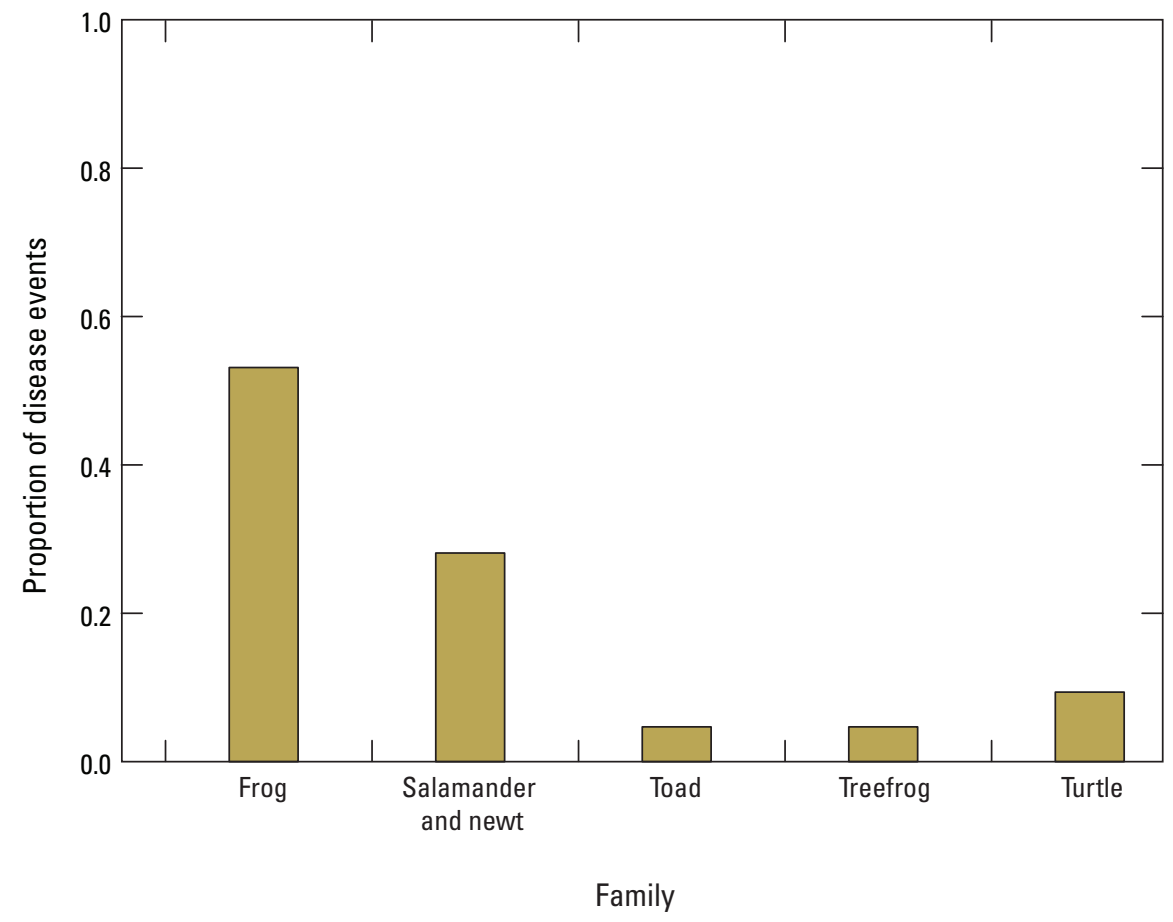

Figure 37. Occurrence of ranavirus in amphibians and turtles, by family. 


\section{A. 2001-5}

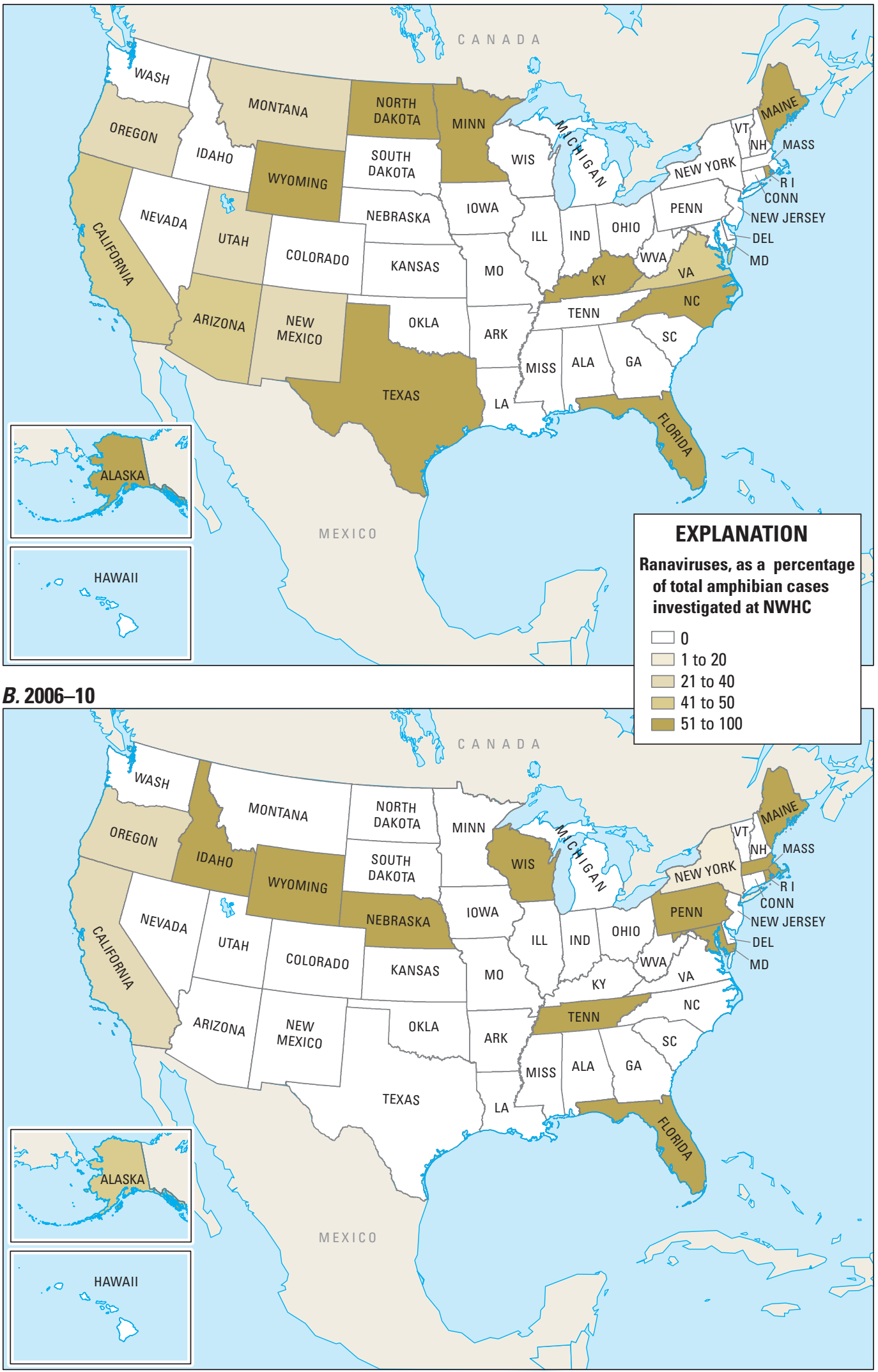

Figure 38. Prevalence of ranaviruses diagnosed in amphibian disease outbreaks, as a percentage of all amphibian disease outbreaks, by State, for $A, 2001-5$ and $B, 2006-10$. 


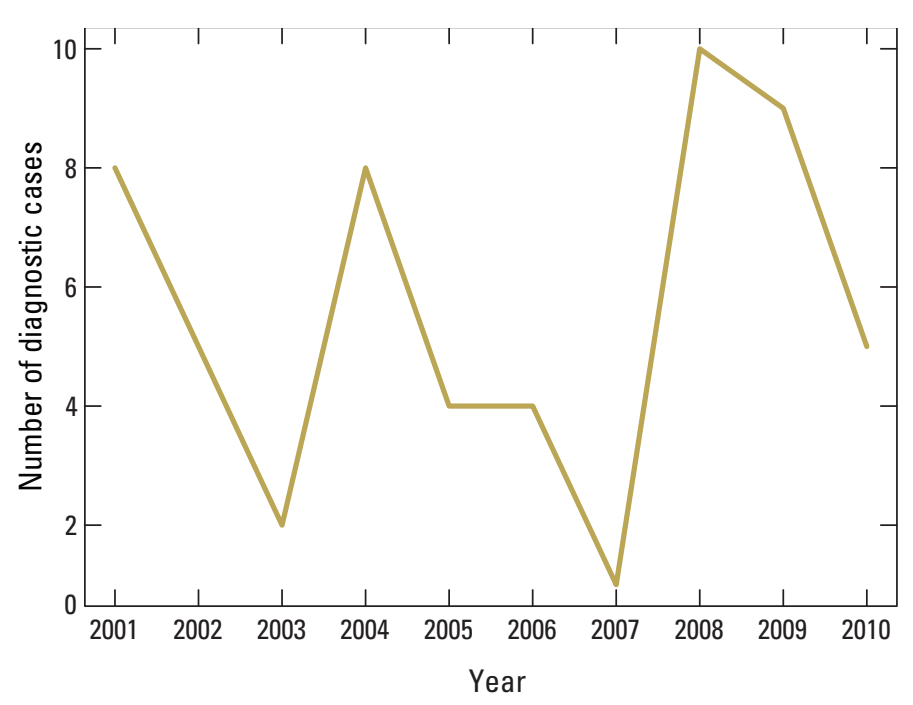

Figure 39. nnual number of cases of ranavirus in amphibians and turtles.

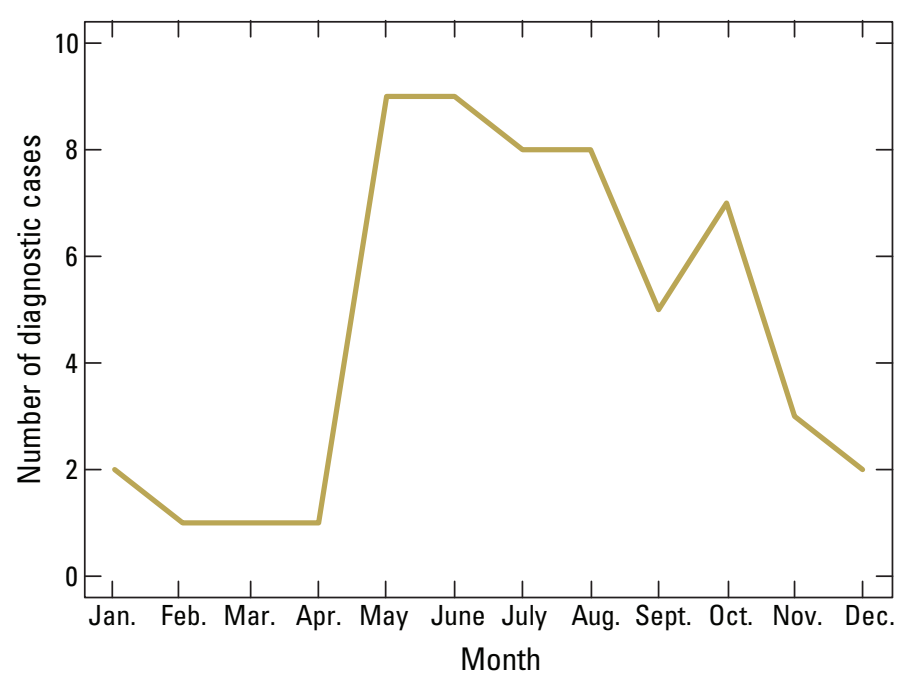

Figure 40. Monthly number of cases of ranavirus in amphibians and turtles.

\section{Signs and Lesions}

Field signs of a ranaviral epizootic are a sudden or explosive onset of morbidity and mortality in a wetland, often with hundreds or thousands of sick and dead amphibians in 1-5 days. Mortality rates in a wetland usually exceed 90 percent. Affected individuals usually present with subtle-to-severe hemorrhages in the ventral skin, especially at the base of the hind limbs and around the vent opening. Hemorrhages may be present from tip of chin to tip of tail ventrally and may be petechial, paintbrush, or focally extensive. These hemorrhages have a tendency to fade with prolonged postmortem intervals or in frozen carcasses. Hence, descriptions of freshly dead amphibians in the field often are very helpful when examining frozen amphibians. Other clinical signs include lethargy, swimming erratically, weakly or on their sides, and mild-tosevere fluid accumulation under the skin in the lymphatic sacs of the abdomen and proximal hind limbs. Internally, there may be clear, fibrinous, or sanguineous fluid accumulation in the body cavity (called hydrocoelom), and petechial or paintbrush hemorrhages on the serosal surfaces of viscera, especially the heart, stomach, and liver. Occasionally, white minute foci of necrosis are evident in the liver or spleen. Ulcers of the skin and palate tend to be randomly scattered, but they are detected in a low percentage of casualties.

\section{Significance and Zoonotic Risk}

At present, ranavirus infections appear to be limited to fish, amphibians, and reptiles, (ectothermic vertebrates). The virus generally cannot be cultured at temperatures above $30^{\circ} \mathrm{C}$, so it probably is not transmissible to domestic animals and humans; however, ranaviruses will grow in bird and mammal cell lines that are incubated at temperatures less than 30 ${ }^{\circ} \mathrm{C}$. At present, ranaviral infections involving more than one class of vertebrates - either fish and amphibians or amphibians and reptiles - at a site are rarely reported in the wild.

\section{Selected References}

Docherty, D.E., Meteyer, C.U., Wang, J., Mao, J., Case, S.T., and Chinchar, V.G., 2003, Diagnostic and molecular evaluation of three Iridovirus-associated salamander mortality events: Journal of Wildlife Diseases, v. 39, p. 556-566.

Hoverman, J.T., Gray, M.J., Miller, D.L., and Haislip, N.A., 2012, Widespread occurrence of ranavirus in pond-breeding amphibian populations: EcoHealth, v. 9, no. 1, p. 36-48, http://dx.doi.org/ 10.1007/s10393-011-0731-9.

Hyatt, A.D., Gould, A.R., Zupanovic, Z., Cunningham, A.A., Hengstberger, S., Whittington, R.J., Kattenbelt, J., and Coupar, B.E.H., 2000, Comparative studies of piscine and amphibian iridoviruses: Archives of Virology, v. 145, p. 301-331.

Miller, D. L., Gray, M. J., and Storfer, A., 2011, Ecopathology of ranaviruses infecting amphibians: Viruses, v. 3, no. 11, p. 2351-2373, accessed August 30, 2012, at http://fwf.ag.utk. edu/mgray/Publications/Milleretal2011.pdf. 
Appendix 1 
Table A1. Total number of bird disease cases by bird group and proportion of bird disease cases by bird group.

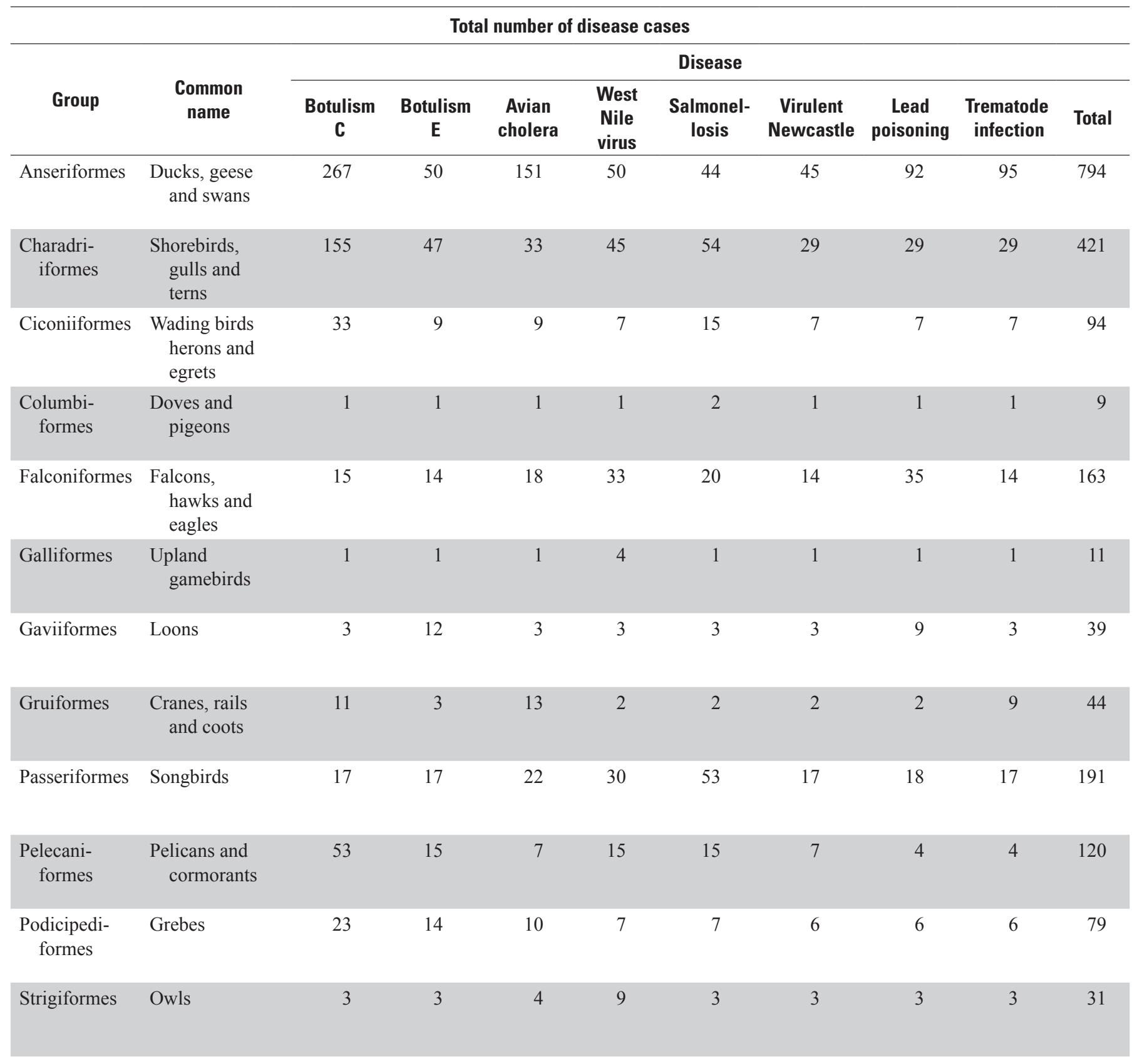


Table A1. Total number of bird disease cases by bird group and proportion of bird disease cases by bird group.-Continued

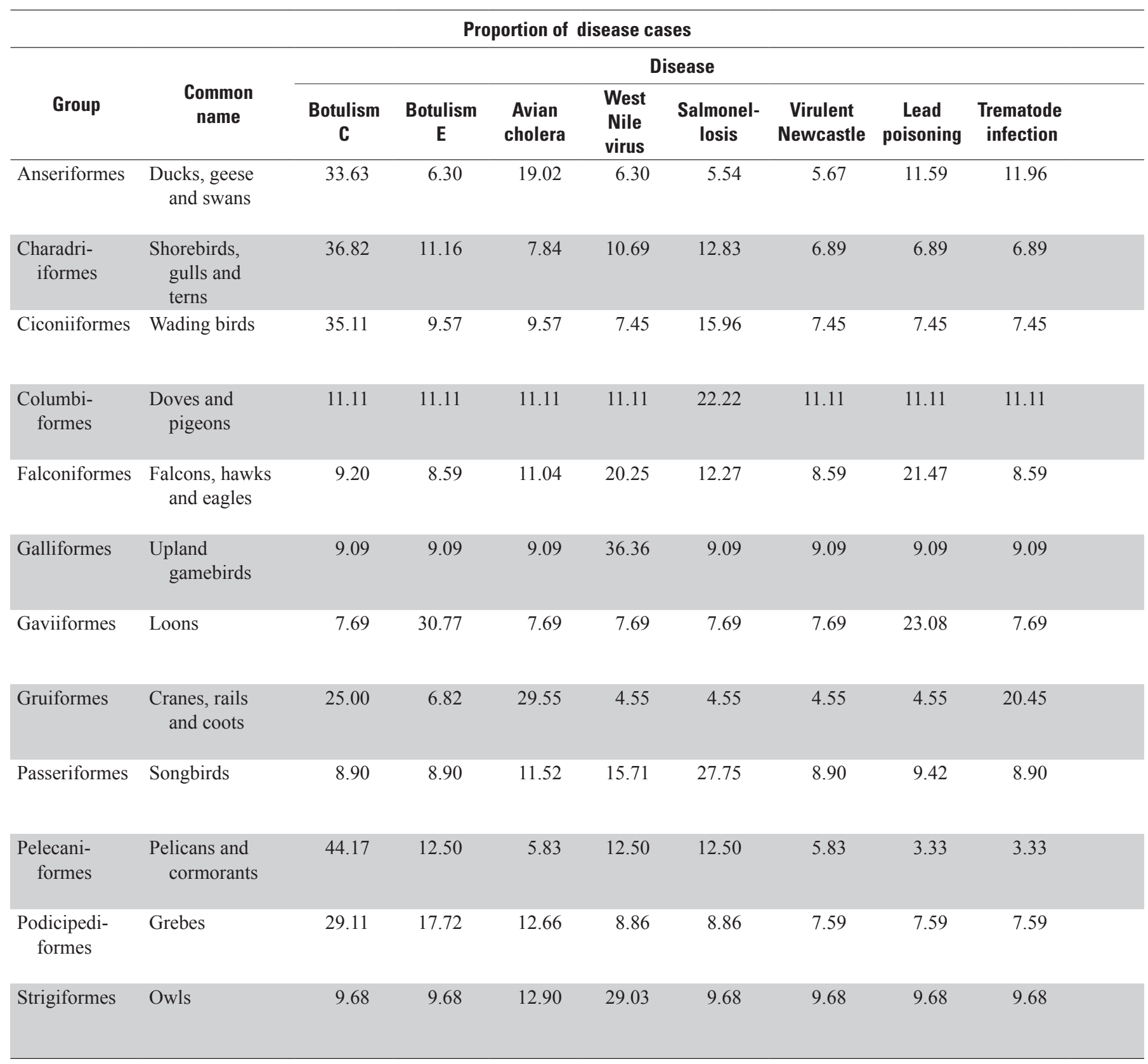




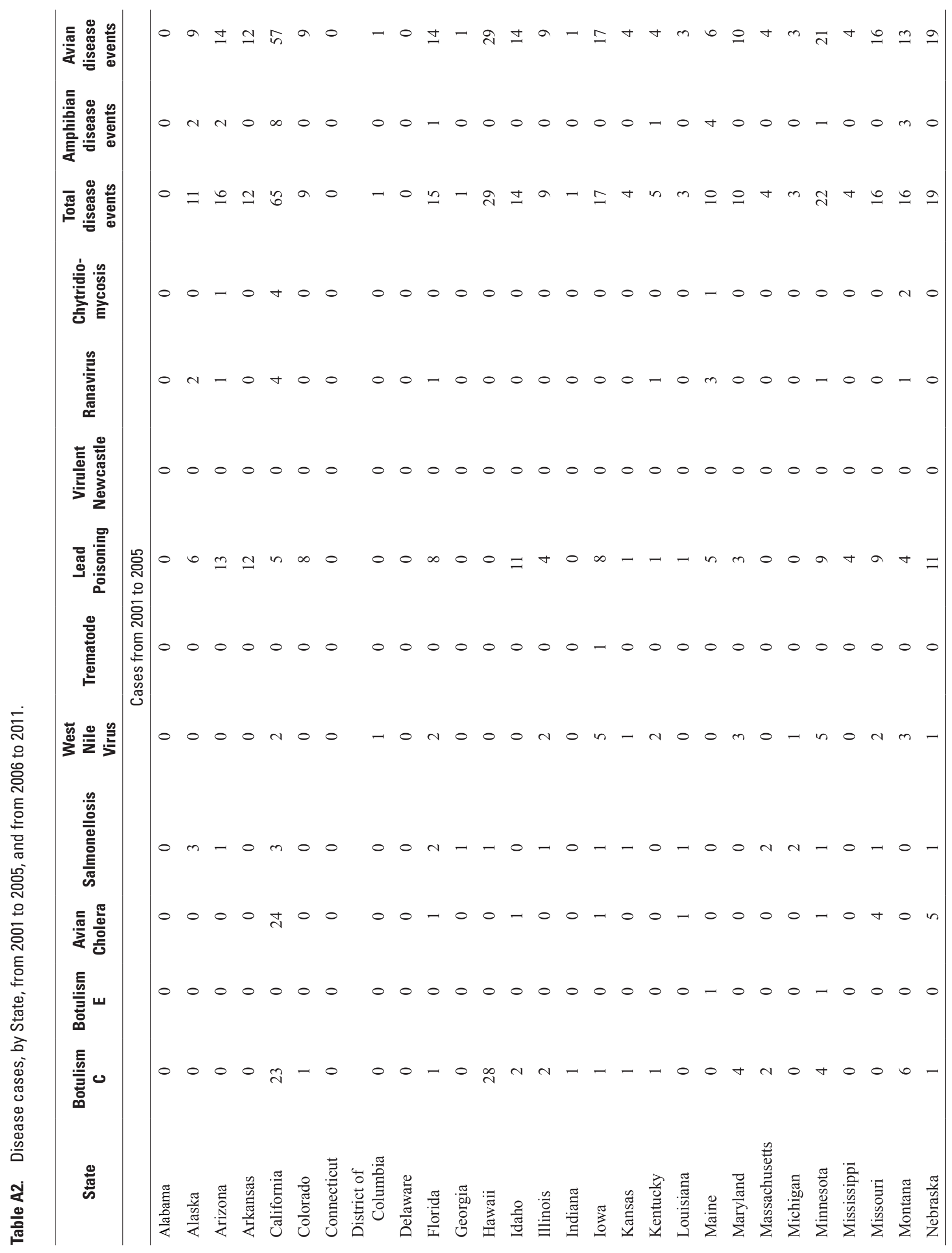




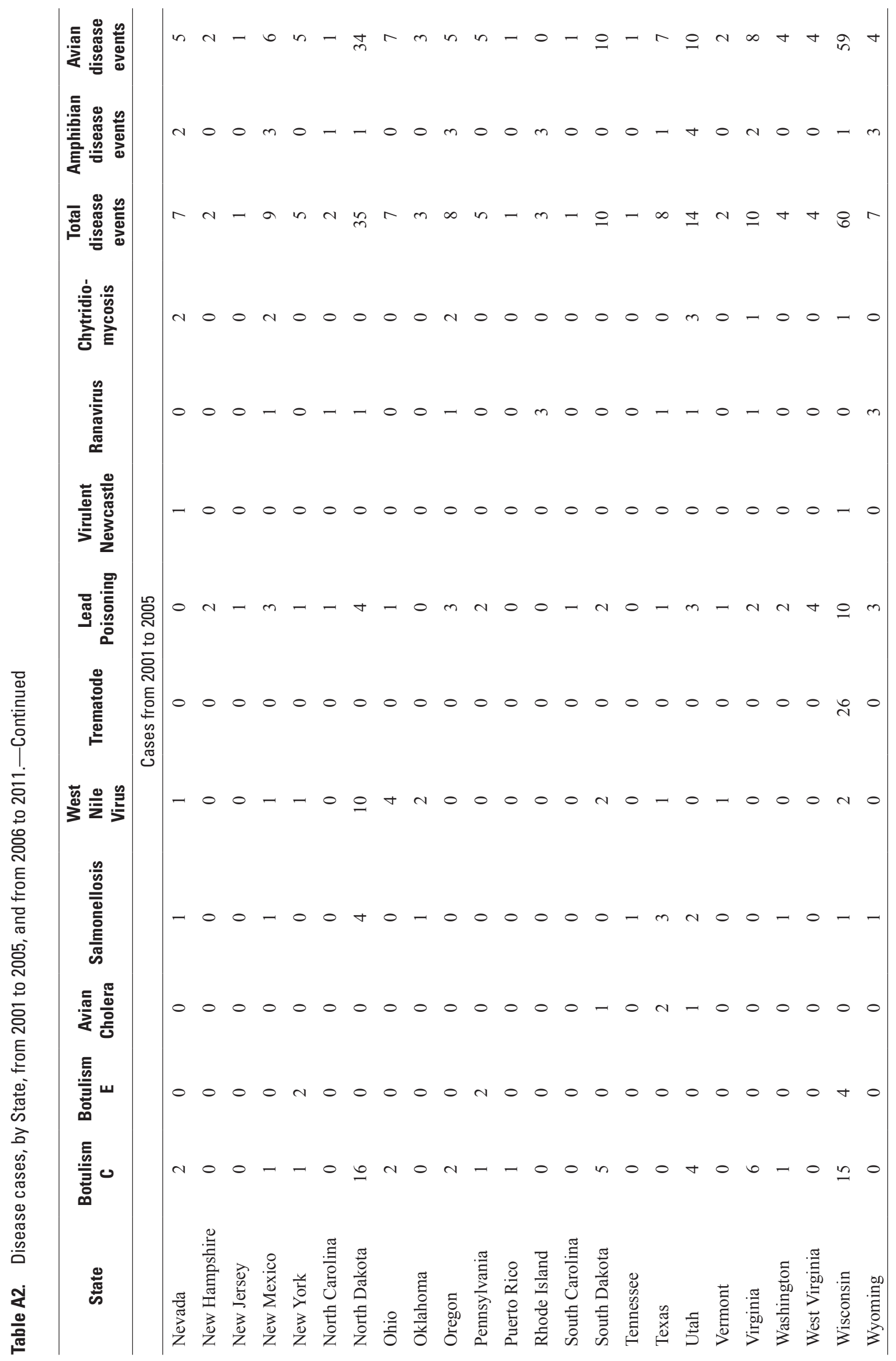




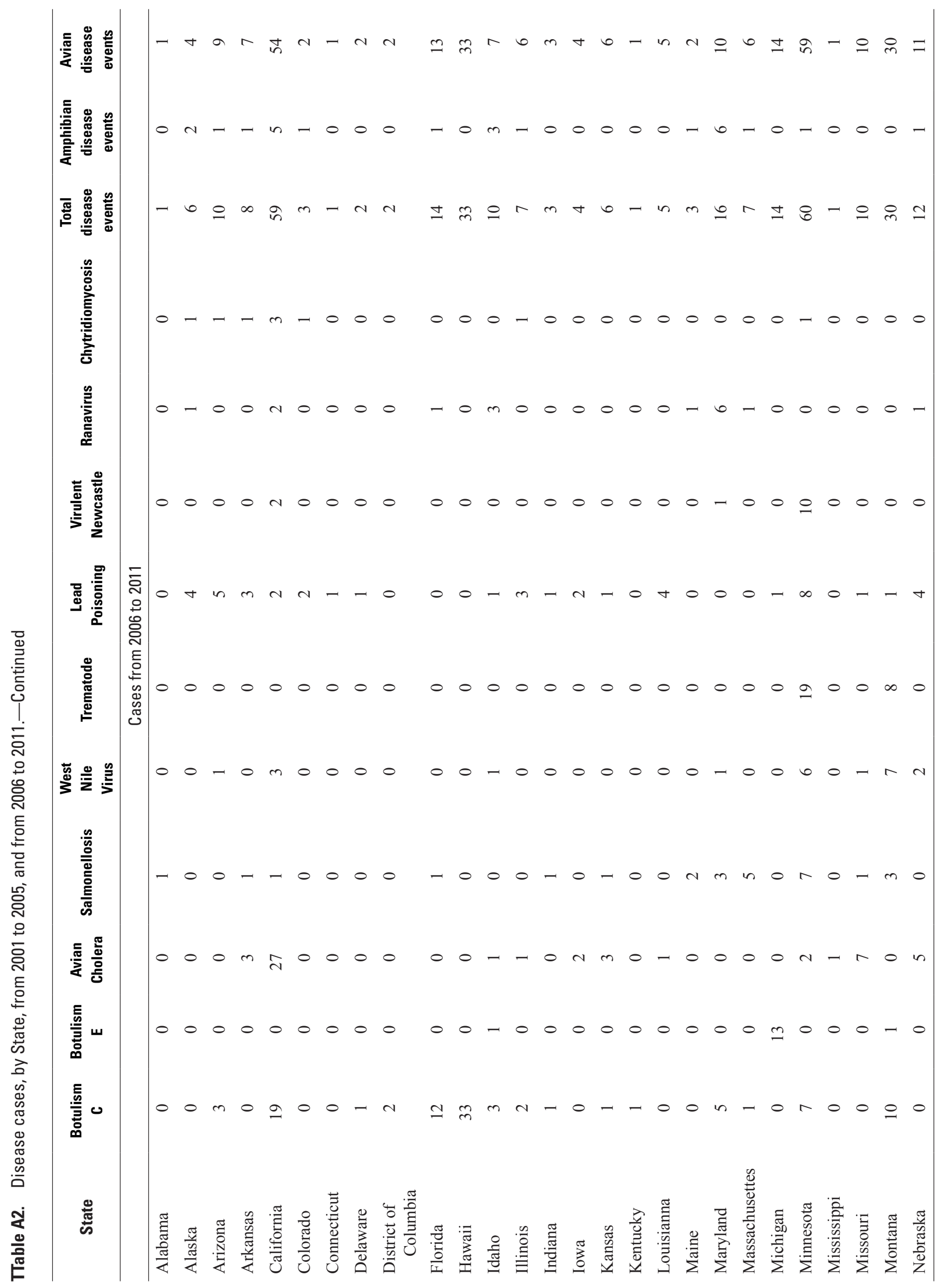








